\title{
Euxinian relict amphipods of the Eastern Paratethys in the subterranean fauna of coastal habitats of the Northern Black Sea region
}

\author{
I.N. Marin ${ }^{1}$, S.V. Krylenko², D.M. Palatov ${ }^{1}$ \\ ${ }^{1}$ A.N. Severtsov Institute of Ecology and Evolution of RAS, Moscow, 119071 Russia. \\ 2 Biological Faculty, M.V. Lomonosov Moscow State University, Moscow, 119992 Russia. \\ E-mails: coralliodecapoda@mail.ru; krylenkoserg@mail.ru; triops@yandex.ru
}

\begin{abstract}
The article presents the first insight into the diversity and distribution of the relatively small Niphargus "tauricus" ingroup of the "stygius" species group (Crustacea: Amphipoda: Niphargidae) living in the coastal caves/springs of Dobrogea in Romania, the Crimean Peninsula and the south-western foothills of the Caucasus Mountains. Six species, namely Niphargus utrishensis Marin et Palatov sp.n., N. novorossicus Marin et Palatov sp.n., N. alisae Marin, Krylenko et Palatov sp.n., N. ashamba Marin, Krylenko et Palatov sp.n., N. malakhovi Marin et Palatov sp.n. and N. dederkoyi Marin et Palatov sp.n. are described from the Black Sea coastal foothills of the south-western part of the Caucasus Mountains. Crimean N. tauricus Birštein, 1964 is re-described based on topotypic material. Morphological diagnoses and descriptions for all species of the "tauricus" ingroup as well as the key for their identification are presented. Aside from the morphological comparisons, DNA barcode (COI mtDNA gene marker) is employed for their identification. It is assumed that these species are Euxinian relicts of the Eastern Paratethys and were settled in their current habitats at the end of the Miocene at least 5 Mya. According to the data obtained, the related species of the ingroup are confined to the same mountain ridge, which suggests that the settlement occurred by several "waves". At the same time, we suppose that the modern species distribution is shaped rather by the uplift of Caucasian coastal mountain ridges and karst fragmentation occurred during the the last 2-3 Mya (since Late Pliocene Early Pleistocene) than the fluctuation of the sea level. Because these animals are not able to disperse actively, we believe that these unique ancient genetic lineages (species) and their biotopes (underground water habitats) are in need of especial protection.

How to cite this article: Marin I.N., Krylenko S.V., Palatov D.M. 2021. Euxinian relict amphipods of the Eastern Paratethys in the subterranean fauna of coastal habitats of the Northern Black Sea region // Invert. Zool. Vol.18. No.3. P.247-320, Supplement 1. doi: 10.15298/invertzool.18.3.05
\end{abstract}

KEY WORDS: diversity, Niphargus, phylogeny, phylogeography, taxonomy, barcoding, subterranean, relicts, foothills, Caucasus, Crimean Peninsula.

The paper is devoted to 70th anniversary of Prof. V.V. Malakhov.

Статья посвящена 70-летию со дня рождения проф., акад. В.В. Малахова. 


\title{
Эвксинские реликтовые амфиподы Восточного Паратетиса в подземной фауне прибрежных местообитаний Северного Причерноморья
}

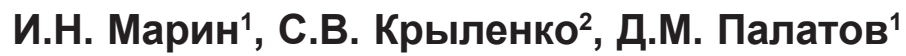 \\ ${ }^{1}$ Институт экологии и эволюции им. А.Н. Севериова РАН, Москва, 119071 Россия. \\ ${ }^{2}$ Биологический факультет Московского государственного университета им. М.В. Ломоно- \\ сова, Москва, 119992 Россия. \\ E-mails: coralliodecapoda@mail.ru; krylenkoserg@mail.ru; triops@yandex.ru
}

РЕЗЮМЕ. В статье представлено первое исследование разнообразия и распространения относительно небольшой ингруппы Niphargus “tauricus” из видовой группы "stygius" (Crustacea: Amphipoda: Niphargidae), обитающей в прибрежных пещерах/ источниках Добруджи в Румынии, на Крымском полуострове и в юго-западных предгорьях Кавказских гор. Шесть видов, а именно Niphargus utrishensis Marin et Palatov sp.n., N. novorossicus Marin et Palatov sp.n., N. alisae Marin, Krylenko et Palatov sp.n., N. ashamba Marin, Krylenko et Palatov sp.n., N. malakhovi Marin et Palatov sp.n. и N. dederkoyi Marin et Palatov sp.n., описываются из предгорий юго-западной части Кавказских гор вдоль берегов Черного моря. Крымский Niphargus tauricus Birštein, 1964 переописан на основе топотипического материала. Представлены морфологические диагнозы и описания для всех видов подгруппы “tauricus”, а также дифференциальный ключ. Помимо морфологических сравнений, для их идентификации используется штрих-код ДНК (маркер гена СОI мтДНК). Предполагается, что изученные виды являются эвксинскими реликтами Восточного Паратетиса и заселили свои нынешние местаобитания в конце миоцена, не менее 5 млн. лет назад. Согласно полученным данным, родственные виды внутри ингруппы приурочены к одному и тому же горному хребту, что позволяет предположить, что заселение происходило несколькими «волнами». В тоже время, мы считаем, что современное распространение видов определяется скорее «ростом» кавказских прибрежных горных хребтов и фрагментацией карста, происходящими последние 2-3 миллиона лет (с поднего плиоцена - раннего плейстоцена), чем колебаниями уровня моря. В связи с тем, что эти животные не способны к активному расселению, мы считаем, что эти уникальные древние генетические линии (виды) и их биотопы (подземные водные среды обитания) нуждаются в особой защите.

Как цитировать эту статью: Marin I.N., Krylenko S.V., Palatov D.M. 2021. Euxinian relict amphipods of the Eastern Paratethys in the subterranean fauna of coastal habitats of the Northern Black Sea region // Invert. Zool. Vol.18. No.3. P.247-320, Supplement 1. doi: 10.15298/invertzool.18.3.05

КЛЮЧЕВЫЕ СЛОВА: Разнообразие, Niphargus, филогения, филогеография, таксономия, штрихкодирование, подземные, реликты, предгорья, Кавказ, Крымский полуостров. 


\section{Introduction}

Current knowledge on the diversity and, especially, the origin and phylogeny of subterranean and hypogean crustaceans from almost all regions of the former USSR, including the Crimean Peninsula and the Caucasus, is currently fragmentary and based mainly on the data provided by regional researchers from the middle and late XX century (e.g., Birtštein, Borutsky, 1950; Birtštein, 1950). At the same time, the Caucasus is the second region of the Western Palearctic (after the Balkan Peninsula) in term of karst area size, variety of landscapes and climatic conditions (e.g., Myers et al., 2000; Krever et al., 2001). Since 2010, recent biospeleological studies in the Crimean Peninsula, the Russian Caucasus and the adjacent regions of Abkhazia have focused mainly on the diversity and ecology of the diplopods (Golovatch, 2011; Golovatch, Chumachenko, 2013; Golovatch et al., 2016; Antić, Makarov, 2016; Antić et al., 2018; Antić, Reip, 2020), cave carabid beetles (Belousov, Koval, 2009, 2011; Giachino, 2011; Reboleira, Ortuno, 2014) and arachnids (Tchemeris, 2013), cave shrimps (Marin, Sokolova, 2014; Marin, 2017, 2018, 2019, 2020; Marin, Turbanov, 2021), crangonyctid (Sidorov, 2015) and gammarid amphipods (Sidorov et al., 2015a, b, 2018; Sidorov, 2016; Sidorov, Samokhin, 2016), woodlice (Gongalsky, Taiti, 2014; Turbanov, Gongalsky, 2016), springtails (Collembola) (Jordana et al., 2012; Vargovitsh, 2012, 2013), false scorpions (Kolesnikov, Turbanov, 2020), stygobiotic gastropods (Vinarski et al., 2014; Grego et al., 2017, 2020; Vinarski, Palatov, 2019; Chertoprud et al., 2020, 2021) and some other subterranean animals (e.g., Golovatch et al., 2018). These data are mostly taxonomic, without any conclusions about the origin and phylogeny of these subterranean animals.

The diversity of the genus Niphargus in the foothills of the Greater Caucasus and the Crimean Peninsula has received slightly less attention (e.g., Karaman, 2012; Marin, 2019; Marin, Palatov, 2019a, 2021; Marin et al., 2021), since it was previously believed that the main diversity of the genus is concentrated in the subtropical humid/wetter part of the Russian Caucasus (for example, in the Sochi region) and Abkhazia. The studies of the origin of the fauna and its phylogeography were based solely on morphological data, that was certainly not enough for a full understanding of the soecies composition. Unfortunately, molecular genetic data on the genus Niphargus from this region are still very limited and fragmentary. At the same time, the study of the foothill regions of the Greater Caucasus is extremely important for understanding the phylogeny and phylogeography of subterranean fauna, since the Crimean Peninsula and the Caucasus were intermediate "bridges" in the development of the faunas of the Transcaucasia and Iran, from where niphargids and other subterranean animals have recently been actively described (e.g., Fišer et al., 2009; Esmaeili-Rineh, Sari, 2013; EsmaeiliRineh et al., 2015a, b, 2016; Bargrizaneh et al., 2021).

Using molecular phylogeny methods, it was established that the Niphargus-like amphipods presumably originated in northwestern Europe (probably northeastern France) in the Upper Cretaceous (about 110-90 Mya), and later, in the Oligocene, about 25 Mya, they spread from Central Europe to the south - to the Balkan/ Apennine Peninsulas and Western Asia (eastern Turkey, Transcaucasia, Iran, etc), connected by a land bridge with the Balkans along the northern coast of the Black Sea at that time (McInerney et al., 2014). Niphargids also inhabited the Baltic Sea coast during the Eocene, since niphargid-like remains are often found in Baltic amber (Coleman, Myers, 2010; Jażdżewski, Kupryjanowicz, 2010). One of the lineages spread widely to the east in the Carpathian region, Central Moldavian Upland and the northern Black Sea region (Birštein, 1950). It was found that the Crimean and Caucasian representatives of the genus Niphargus are phylogenetically related to both Eastern Balkan and Iranian species (Esmaeili-Rineh et al., 2015a). Currently, Niphargus vadimi Birštein, 1961, N. dimorphus Birštein, 1961 and N. tauricus Birštein, 1964 are endemic to the Crimean Peninsula, and their phylogenetic position within the genus as well 
as their phylogeography are somewhat unclear. It is assumed that the stygobiotic fauna of the Crimea Peninsula is certainly descended from Balkan ancestors, while the colonization of the Crimean Peninsula and the Caucasus occurred independently, since the species from these nearby regions are closer to the Balkanian and European relatives than to each other (Birštein, 1961; Birštein, Ljovushkin, 1967). However, all these conclusions were based only on the study of morphological features without the use of molecular methods. Also, there is a large gap in the distribution of niphargids in the foothills of the Caucasus, where they have not yet been found.

In 2018-2020, during the studying the diversity of hypogean and subterranean fauna in the western foothill of the Caucasus and along the north-eastern Black Sea coastal ridges into the Kolkhida coastal valley (Colchis), numerous subterranean (hypogean) water sources inhabited by the genus Niphargus were sampled. The collected niphargids were found to be genetically and morphologically very close to the Crimean Niphargus tauricus Birštein, 1964, the species previously assumed (after EsmaeiliRineh et al., 2015a) as closely related to the Romanian Niphargus dobrogicus Dancãu, 1964, known from coastal wells (50-200 m from the Black Sea coast) of the Dobrogea region in eastern Romania (Dancãu, 1964), and no Caucasian relatives were expected for this species. Moreover, another species (related both to newly disovered Caucasian and Crimean $N$. tauricus, according to our research) was $N$. dancaui Brad, Fišer, Flot et Sarbu, 2015, described from coastal caves and springs in the Dobrogea, Romania, which also was unexpected, since no comparison with $N$. tauricus was presented in the original description of this species (Brad et al., 2015). After the described preliminary investigation, we understood that these species form a rather wellseparated ingroup within the genus, which needed to be studied in detail.

The main objectives of this study are: (1) to provide a detailed morphological and genetic analysis of the discovered Caucasian Niphar- gus species related to the Crimean N. tauricus, and (2) to reconstruct their phylogenetic relationships with other related species and phylogeographic patterns in order to determine the time and ways of their colonization of the Caucasus and other regions.

\section{Material and methods}

SAMPLECOLLECTIONAND PROCESSING. Amphipods were collected in small streams and wells by a dip net. Live specimens of the genus Niphargus were transported to the laboratory, relaxed with clove oil and photographed using a Canon G16 digital camera. All collected specimens were preserved in $90 \%$ ethanol for further DNA analysis. The body length (bl., $\mathrm{mm}$ ), the dorsal length from distal margin of head to the posterior margin of telson, without the length of uropod III and antennas, is used as a standard measurement. The scanning electron microscopy (SEM) images were made at the Paleontological Museum of the Paleontological Institute of the Russian Academy of Sciences, Moscow, using Vega3 Tescan microscope. In general, we attempted to include localities in which at least one specimen was sequenced for molecular analysis. The photos of the Caucasian coastal ridge (Fig. 2B, E) were taken from an Aeroflot regular flight from Gelendzhik to Moscow in June 2018; the other illustrations (Figs 2A, C, D; 3) were prepared using the Google maps. The type material is deposited at the collection of the Zoological Museum of Moscow State University, Moscow (ZMMU); other (additional) material is deposited in personal authors' collection (LEMMI).

AMPLIFICATION ANDDNA SEQUENCING. To enravel the cryptic diversity of the group a fragment of cytochrome oxidase $\mathrm{C}$ subunit I(COI mtDNA) was used. Total genomic DNA was extracted from abdominal and pereopod muscle tissue using the innuPREP DNA Micro Kit (AnalitikJena, Germany) following the manufacturer's protocol. The gene marker was amplified with the help of the universal primers LCO1490 (5'-GGTCAACAAATCATAAAGATATTGG-3') and 
HC02198 (5'-TAAACTTCAGGGTGACCAAAAAATCA-3') (Folmer et al., 1994) using T100 amplificator (Bio-Rad, USA) under the following conditions: initial denaturation at $96{ }^{\circ} \mathrm{C}$ for $1.5 \mathrm{~min}$ followed by 42 cycles of $95{ }^{\circ} \mathrm{C}$ for $2 \mathrm{~min}, 49^{\circ} \mathrm{C}$ for 35 seconds, and $72{ }^{\circ} \mathrm{C}$ for $1.5 \mathrm{~min}$, followed by chain extension at $72{ }^{\circ} \mathrm{C}$ for $7 \mathrm{~min}$. The volume of $10 \mu \mathrm{L}$ of reaction mixture contained $1 \mu \mathrm{L}$ of total DNA, $2 \mu \mathrm{L}$ of $5 \times$ PCR mix (Dialat, Russia) and $1 \mu \mathrm{L}$ of each primer.

PHYLOGENETIC ANALYSIS. Consensus of complementary sequences was obtained with MEGA 7.0. Relationships of the "tauricus" ingroup were tested using the obtained sequences of COI mtDNA gene markers, 646 base pairs in length, and all available data from the GenBank (NCBI) database using various phylogenetic tools. Additionally, 121 sequences of the related species and outgroup (Niphargus irlandicus Schellenberg, 1932 and N. glennei (Spooner, 1952)) were taken from the GenBank (NCBI) database, and finally the final dataset for the analysis included 167 sequences, displaying 295 variable (polymorphic) sites, of which 288 were parsimony informative. Phylogenetic tree topologies were congruent between Bayesian and Maximum Likelihood analyses. The considered ingroup of Caucasian species, Crimean N. tauricus and Romania N. dancaui (KF290222, KF290230-KF090232, KF090241, KF090243, KF090245, KF090247, KF090249, KF090250, KF090257, KF090272-KF090275, KY707071), was found to be monophyletic in the concatenated tree (posterior probability value, $\mathrm{PP}=100$, bootstrap value, $B=99$ ). The general phylogenetic position of the studied "tauricus" ingroup within the genus Niphargus was also compared with the general phylogenetic tree of the genus, presented by Copilaş-Ciocianu et al. (2018: Fig. 1) and Fišer et al. (2018a, b; 2019); the adapted time-scale is used after McInerney et al. (2014) (see Fig. 1).

The genetic divergences ( $p$-distances) were calculated with MEGA 7.0 using the Kimura 2Parameter (K2P) model of evolution (Kimura, 1980) with the sequences of the relative species, deposited in GenBank (NCBI) database. The best evolutionary substitution model was determined using MEGA 7.0. and jModeltest2.1.141 on XSEDE via the CIPRES (Cyber Infrastructure for Phylogenetic Research) Science Gateway V. 3.3 (http://www.phylo.org/). Phylogenetic analysis was performed on single gene marker dataset (COI mtDNA) using PhyML 3.0 (http://www.atgc-montpellier.fr/phyml/) using GTR + G + I model for Maximum-Likelihood analysis (ML). The obtained phylogenetic trees were compared with the general phylogenetic tree of the genus Niphargus, presented by Copilaş-Ciocianu et al. (2018) and Fišer et al. (2018a, 2019).

SPECIES DELIMITATION. The species delimitation was explored under three different approaches using single-locus discovery tools: distance clustering ABGD (Automatic Barcode Gap Discovery) (Puillandre et al., 2011) (http:/ /wwwabi.snv.jussieu.fr/public/abgd/), phylogeny-aware PTP (Poisson Tree Process) (Zhang et al., 2013) and Bayesian GMYC (Generalized Mixed Yule Coalescent) (Pons et al., 2006; Reid, Carstens, 2012) as well as morphological evidence.

The ABGD analysis was performed using an online version of the program (https:// bioinfo.mnhn.fr/abi/public/abgd/abgdweb.html) with the default program settings (Pmin: 0.001; Pmax: 0.1; steps: 10 ; Nb bins: 20); relative gap width (X) was evaluated as 0.1 and 1.0 ); distances were calculated using the Jukes-Cantor (JC69) substitution model as the model of nucleotide evolution.

Poisson Tree Process (PTP) and the Bayesian variant of the method (bPTP) (https:// species.h-its.org/) was run on the RAxML gene trees (see above) for $1 \times 10^{6}$ MCMC (Markov chain Monte Carlo) generations thinning every 1000 and removing the distant outgroup that can improve the delimitation results.

In GMYC analysis, the phylogenetic analyses were run in the BEAST2 package (Drummond et al., 2012; Drummond, Bouckaert, 2015; Bouckaert et al., 2014, 2019) using GTR, TN93 and HKY models, Yule process and Coalescent (constant size) tree priors and strict clock model. The MCMC chains were run for $10 \times 10^{6}$ 


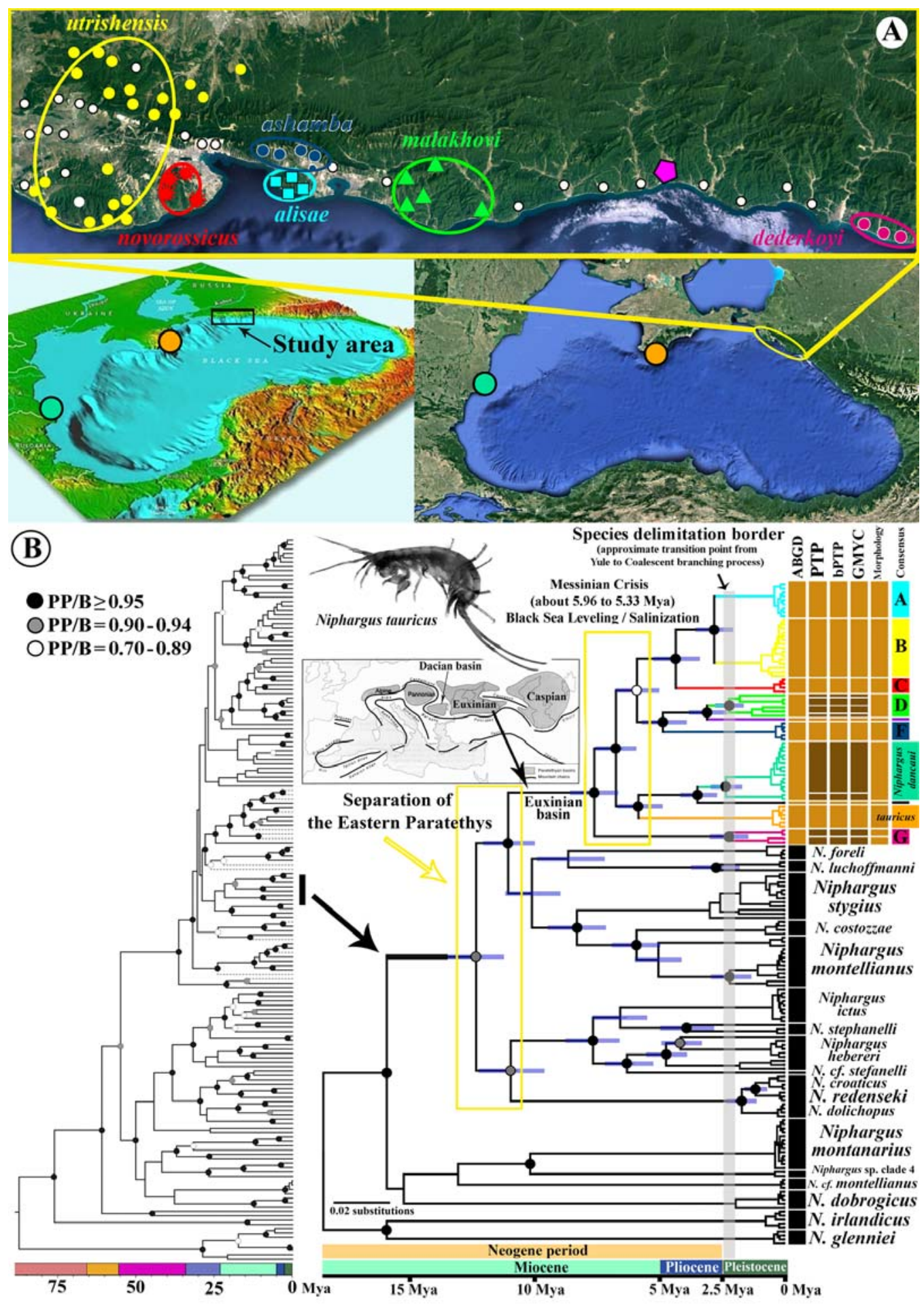


generations sampling every $10^{4}$ generations were used. The best-scoring Bayesian Inference trees were estimated using GTR model, used for further analysis. Following gene tree inference, GMYC was implemented in the "splits" package (SPecies LImits by Threshold Statistics) (Ezard et al., 2009) of the R software environment R v.3.5.1 (http://www.r-project.org/) with a single threshold used for COI mtDNA gene marker.

MOLECULAR CLOCK ANALYSIS was performed based on Bayesian Inference trees generated by GMYC analysis with the BEAST2 package (see above). A Maximum Clad Credibility Tree was obtained using TreeAnnotator v2.5.1, with $10 \%$ burn-in and selected mean node height (Bouckaert et al., 2014). The resulting trees were visualized with FigTree v1.4.3. Calibration points were chosen based on the adapted time-scale (McInerney et al., 2014) and the analysis of historical events.

The final visualization is presented on Fig. 1 , showing the maximum clade credibility BA tree with the supported species-delimitation schemes under each method, and then summarizing consensus between methods and stating how disagreements were resolved and considered for species-tree analyses. There were considerable differences among species delimitation methods with respect to the number of distinct species.

\section{Results}

PHYLOGENETIC APPROACH. The molecular genetic analysis (Fig. 1) clearly confirmed the monophyly (Bayesian - $\mathrm{PP}=1.00$; ML - BS $=95 \%$ ) of the studied "tauricus" ingroup and also supports its close relationships with the European "stygius" species group, including such species as Niphargus stygius (Schiödte, 1847), N. foreli Humbert, 1876, N. montellianus Stoch, 1998, N. luchoffmanni Fišer, Alther, Zaksek, Borko, Fuchs et Altermatt, 2018, N. costozzae Schellenberg, 1935 as well as other species from Northern Italy, Switzerland and Slovenia (see Fig. 1; Table 2) (e.g., Brad et al., 2015), than to any Caucasian species or species group, which indicates their independent settlement in the Caucasus. Previously suggested close relationship of the "tauricus" ingroup with $N$. dobrogicus Dancãu, 1964, known from the Black Sea coastal habitats of Romania (EsmaeiliRineh et al., 2015a) had no confirmation (see Fig. 1; Table 2). The COI mtDNA gene tree (Fig. 1) showed a strong support of the terminal and intermediate branches, while the use of nuclear gene markers gives a weaker support due to the slower evolution of nuclear genes in this group (e.g., Fišer et al., 2009, 2018a, 2019; CopilaşCiocianu et al., 2018).

The ABGD analysis performed 20 OTUs with the prior maximal distance $\mathrm{P}=0.059948$

Fig. 1. The map of distribution (A), the time-calibrated phylogenetic tree (reconstruction) and the species delimitation analyses on COI mtDNA gene marker of the studied Niphargus "tauricus" ingroup (B). Posterior probabilities of the nodes are reported. Vertical scales represent the results of species delimitation analyses using Automatic Barcode Gap Discovery (ABGD), Poisson Tree Processes (PTP and bPTP), General Mixed Yule Coalescent (GMYC), morphological evidences (Morphology) and the summary coincident results (Consensus) of different species delimitation approaches. Blue horizontal bars show the 95\% HPD (highest posterior density) of node ages on an arbitrary time scale. White dots represent the localities (mostly, coastal springs), where niphargids were not found. The general phylogenetic tree is taken from Fišer et al. (2019) with the adapted time-scale after McInerney et al. (2014).

Рис. 1. Карта распространения (А), откалиброванное по времени филогенетическое дерево (реконструкция) и анализ видовой принадлежности по генному маркеру СОI мтДНК исследуемой ингруппы Niphargus "tauricus" (Б). Представлены апостериорный вероятности основных узлов. Вертикальные шкалы представляют результаты анализа делимитации видов с использованием Automatic Barcode Gap Discovery (ABGD), Poisson Tree Processes (РTР и ьPTP), General Mixed Yule Coalescent (GMYC), морфологических признаков (Morphology) и сводных результатов (Consensus) различных подходов к делимитации видов. Синие горизонтальные полосы показывают 95\% HPD возраста узлов в произвольном масштабе времени. Белыми точками обозначены локации (в основном прибрежные источники), где нифаргусы не были встречены. Общее филогенетическое дерево взято из Fišer et al. (2019) с адаптированной временной шкалой по McInerney et al. (2014). 

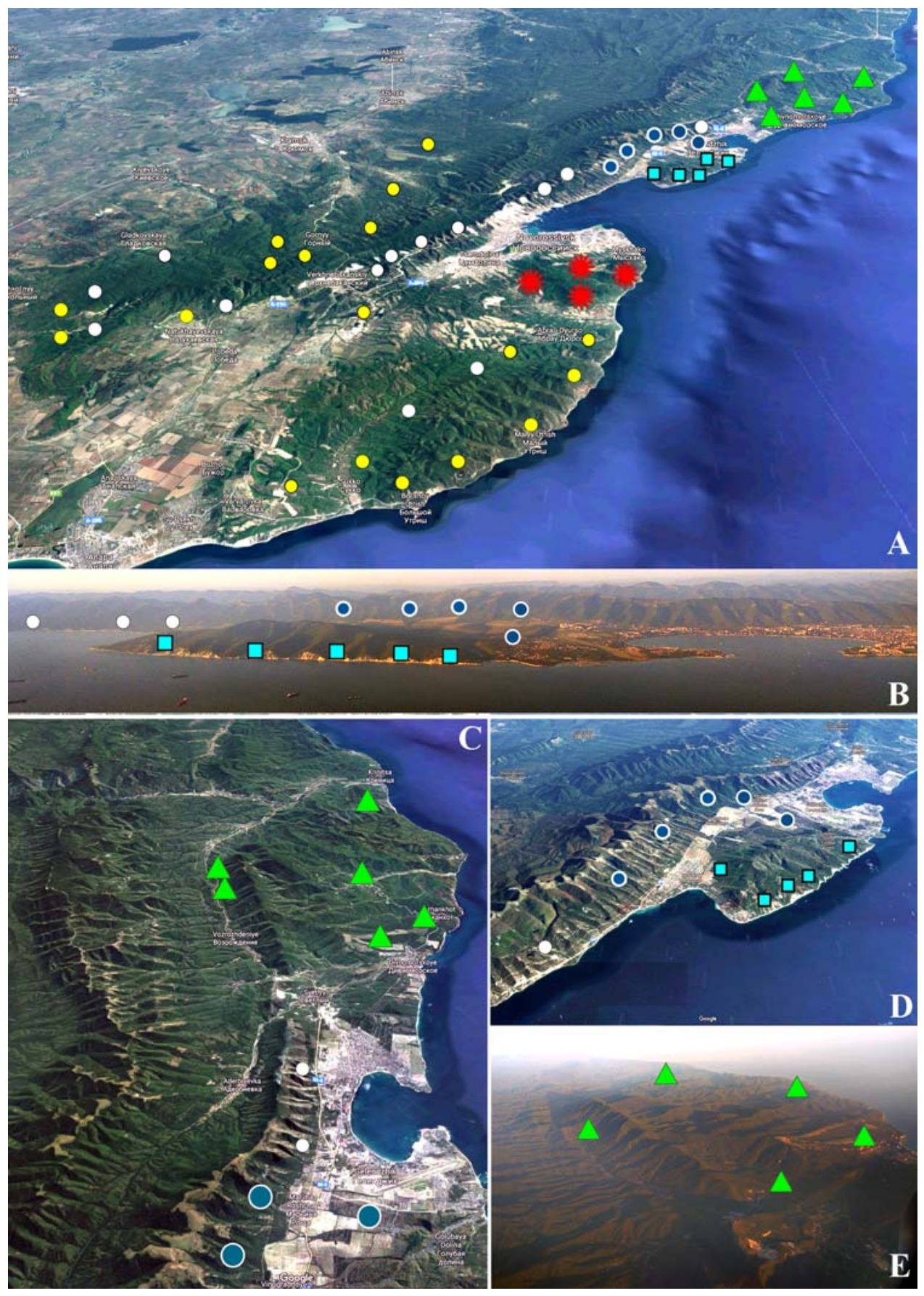

Fig. 2. The map of distribution of different lineages of the Niphargus "tauricus" ingroup in the foothills of the Great Caucasus: A, B, D - Gelendzhik area (Tuaphat Ridge); C, E - Dzankhot area (for color designations of the lineages/species see Fig. 1).

Рис. 2. Карта распространения различных видов ингруппы Niphargus "tauricus" предгорий Большого Кавказа: А, Б, Г - Геленджикский район (хребет Туапхат); В, Е - район Джанхота (цветовые обозначения видов см. рис. 1). 
and 27 putative species (i.e., operational taxonomic units, OTUs) with the prior maximal distance $\mathrm{P}=0.035938$, while the analyzed group includes 1 OTU and 10 OTUs, respectively. Species delimitation analyses performed by implementing the coalescent tree-based approach (i.e., GMYC, PTP and bPTP) led to almost identical results but some differences were apparent relative to ABGD (Fig. 1). The ML (GMYC) model is 1314.148 , compared to the likelihood of the null model 1284.612. As a result of the likelihood ratio test, the null model expecting uniform coalescent branching rates across entire tree was rejected (likelihood ratio $=59.07224, \mathrm{p}=1.487699 \mathrm{e}-13)$. The number of ML clusters in the analysis is 46 (confidence interval: 43-50), while the analyzed ingroup includes $15 \mathrm{ML}$ entitles $(95 \% \mathrm{CI})$. The trees resulting from PTP, bPTP and GMYC present similar results (Fig. 1) with 15 OTU in the studied ingroup (Fig. 1). The morphological analysis (see below) strongly supports the presence of only 10 separate species within the studied "tauricus" ingroup. Thus, an integrative approach to species delimitation resulting in the phylogenetic tree (see Fig. 1) strongly supported three well resolved major clades and confirmed the presence of at least 10 subclades, representing separate species (see Fig. 1).

The origin of the "tauricus" ingroup, its separation from the related lineages, was estimated to be of Miocene age, about $11 \mathrm{Mya}(95 \%$ HPD: 12.1-9.6), it is possibly related to the separation of the Euxinian basin of the Eastern Paratethys. Divergence time between the main Clades I-III of the ingroup, was estimated as Late Miocene, about 7-5 Mya, and possibly occurred because of the global Messinian crisis, when the level of the Eastern Paratethys and the remaining reservoirs (Black Sea) fell down to very low values (Fig. 1). As a result of these events, large phylogenetic lineages remained along the coastline of the Black Sea - in Romania, the Crimean Peninsula and the foothills of the Caucasus. The Clade I (A-F) includes the lineages (species) associated with the foothills of the Russian Caucasus, separated for two major subclades, associated with Markotkh and Navagirsky (Tuaphat) Ridges (see Fig. 3), separated in the Pliocene, about 5.5 Mya (95\%HPD: 7.2-4.8). Further significant proliferation within this Clade, probably, occurred mostly in the Pliocene. The Clade II includes two main lineages of Romanian N. dancaui and Crimean $N$. tauricus; this split occurred about 4.5 Mya (95\%HPD: 7.2-4.8) during the Late Miocene. The Clade III (G) includes the lineages (species) from the Black Sea coast of the Great Caucasian Ridge (see Fig. 3), diverged from others in the Late Miocene, about 7 Mya (95\%HPD: 8.1-6.1).

The intraspecific genetic differences ( $p$-distances) of COI mtDNA gene marker within the subclades (species) of the "tauricus" ingroup is the lowest in Niphargus ashamba sp.n. $(\mathrm{n}=5)$ $(0.0019$ substitutions per 100 nucleotides, about $0.2 \%), N$. alisae sp.n. $(\mathrm{n}=9)(0.0021$, about 0.2 $\%), N$. novorossicus sp.n. $(\mathrm{n}=5)(0.0023$, about $0.2 \%), N$. tauricus $(\mathrm{n}=6)(0.0027$, about $0.3 \%)$ and $N$. utrishensis sp.n. $(\mathrm{n}=15)(0.0051$, about $0.5 \%$ ), while $p$-distances are relatively high in $N$. dancaui $(0.0187$, about $2 \%), N$. dederkoyi sp.n. $(\mathrm{n}=4)(0.0257$, about $3 \%)$ and $N$. malakhovi sp.n. $(\mathrm{n}=7)(0.0430$, about $4 \%)$. The interspecific genetic differences ( $p$-distances of COI mtDNA gene marker) between the species within the "tauricus" ingroup mostly vary from 5 to $10 \%(0.046-0.105$ substitutions per 100 nucleotides) (Table 1), which justifies the erection of the new species (Hebert et al., 2003; CopilaşCiocianu et al., 2017; Delić et al., 2017; Zakšek et al., 2019). The difference from Crimean $N$. tauricus is about $9.5 \%$ (0.094 substitutions per 100 nucleotides) and from Romania $N$. dancaui is about $13 \%$ ( 0.127 substitutions per $100 \mathrm{nu}-$ cleotides) (Table 2). The interspecific genetic differences ( $p$-distances of COI mtDNA gene marker) between the species of the "tauricus" ingroup and related European species (as well as other species with available genetic data from the GenBank (NCBI) database) exceed 13\% (0.13 substitutions per 100 nucleotides) (Table 2). The divergent time of the "tauricus" ingroup from the most related European species is estimated using $p$-distances between $2.56 \pm 0.25 \mathrm{Mya}$ to $17.14 \pm 1.69$ Mya, with the average about 5-6 
Table 1. Pairwise genetic (COI mtDNA) distances ( $p$-distances) (substitutions per 100 nucleotides) with the Niphargus "tauricus" ingroup.

Таблица 1. Попарные генетические (COI мтДНК) расстояния (р-дистанции) (замены на 100 нуклеотидов) в ингруппе Niphargus "tauricus".

\begin{tabular}{|c|c|c|c|c|c|c|c|}
\hline Niphargus & utrishensis & alisae & novorossicus & ashamba & malakhovi & dederkoyi & tauricus \\
\hline utrishensis & & & & & & & \\
\hline alisae & 0.046 & & & & & & \\
\hline novorossicus & 0.065 & 0.072 & & & & & \\
\hline ashamba & 0.084 & 0.090 & 0.077 & & & & \\
\hline malakhovi & 0.082 & 0.086 & 0.081 & 0.075 & & & \\
\hline dederkoyi & 0.092 & 0.102 & 0.100 & 0.105 & 0.095 & & \\
\hline tauricus & 0.087 & 0.099 & 0.101 & 0.091 & 0.091 & 0.108 & \\
\hline dancaui & 0.120 & 0.129 & 0.137 & 0.134 & 0.117 & 0.149 & 0.116 \\
\hline
\end{tabular}

Table 2. Pairwise genetic (COI mtDNA) distances ( $p$-distances) and estimated divergence time (Min. and Max. after Guy-Haim et al. (2018); average - 2.5\% $\mathrm{Mya}^{-1}$ for COI mtDNA gene marker after Lefébure et al. (2006), Copilaş-Ciocianu, Petrusek (2015)) between the species of the "tauricus" ingroup and other related European species of the genus Niphargus (data from GenBank (NCBI) database).

Таблица 2. Попарные генетические расстояния (COI mtDNA) ( $p$-дистанции) и расчетное время дивергенции (Мин. и Макс. согласно Guy-Haim et al. (2018); среднее значение - 2,5\% $\mathrm{Mya}^{-1}$ для генного маркера COI mtDNA (согласно Lefébure et al. (2006) и Copilaş-Ciocianu, Petrusek (2015)) между видами ингруппы “tauricus" и другими родственными европейскими видами рода Niphargus (из базы данных GenBank (NCBI)).

\begin{tabular}{|c|c|c|c|c|}
\hline \multirow[b]{2}{*}{ Species } & \multirow[b]{2}{*}{$p$-distance } & \multicolumn{3}{|c|}{ Approximate divergence time (Mya) } \\
\hline & & $\begin{array}{c}\text { Max } \\
(0.0077 / \mathrm{Mya})\end{array}$ & $\begin{array}{c}\text { Average } \\
(0.025 / \mathrm{Mya})\end{array}$ & $\begin{array}{c}\text { Min } \\
(0.0516 / \mathrm{Mya})\end{array}$ \\
\hline $\begin{array}{l}\text { Niphargus tauricus } \\
\text { (Crimean Peninsula) }(\mathrm{n}=6)\end{array}$ & $0.094 \pm 0.011$ & $21.21 \pm 1.43$ & $3.76 \pm 0.44$ & $1.82 \pm 0.21$ \\
\hline Niphargus dancaui (Romania) $(\mathrm{n}=15)$ & $0.127 \pm 0.013$ & $16.49 \pm 1.69$ & $5.08 \pm 0.52$ & $2.46 \pm 0.25$ \\
\hline $\begin{array}{l}\text { Niphargus luchoffmani } \\
\text { (Switzerland) }(\mathrm{n}=3)\end{array}$ & $0.132 \pm 0.013$ & $17.14 \pm 1.69$ & $5.28 \pm 0.52$ & $2.56 \pm 0.25$ \\
\hline $\begin{array}{l}\text { Niphargus montellianus } \\
\text { (Northern Italy) }(\mathrm{n}=8)\end{array}$ & $0.151 \pm 0.014$ & $19.61 \pm 1.82$ & $6.04 \pm 0.56$ & $2.93 \pm 0.27$ \\
\hline $\begin{array}{l}\text { Niphargus stefanelli } \\
\text { (Northern Italy) }(\mathrm{n}=4)\end{array}$ & $0.156 \pm 0.014$ & $20.26 \pm 182$ & $6.24 \pm 0.56$ & $3.02 \pm 0.27$ \\
\hline Niphargus foreli (Switzerland) $(\mathrm{n}=4)$ & $0.156 \pm 0.014$ & $20.26 \pm 1.82$ & $6.24 \pm 0.56$ & $3.02 \pm 0.27$ \\
\hline $\begin{array}{l}\text { Niphargus croaticus-redenseki } \\
\text { (Croatia) }(\mathrm{n}=5)\end{array}$ & $0.157 \pm 0.015$ & $20.39 \pm 1.95$ & $6.28 \pm 0.60$ & $3.04 \pm 0.29$ \\
\hline $\begin{array}{l}\text { Niphargus dolichopus } \\
\text { (Bosnia and Herzegovina) }(\mathrm{n}=4)\end{array}$ & $0.157 \pm 0.015$ & $20.39 \pm 1.95$ & $6.28 \pm 0.60$ & $3.04 \pm 0.29$ \\
\hline Niphargus stygius (Slovenia) $(\mathrm{n}=12)$ & $0.159 \pm 0.015$ & $20.65 \pm 1.95$ & $6.36 \pm 0.60$ & $3.08 \pm 0.29$ \\
\hline $\begin{array}{l}\text { Niphargus montanarius } \\
(\text { Northern Italy) }(\mathrm{n}=7)\end{array}$ & $0.160 \pm 0.015$ & $20.78 \pm 1.95$ & $6.40 \pm 0.60$ & $3.10 \pm 0.29$ \\
\hline Niphargus ictus (Northern Italy) $(\mathrm{n}=9)$ & $0.166 \pm 0.015$ & $21.56 \pm 1.95$ & $6.64 \pm 0.60$ & $3.22 \pm 0.29$ \\
\hline $\begin{array}{l}\text { Niphargus costozzae } \\
\text { (Northern Italy) }(\mathrm{n}=5)\end{array}$ & $0.170 \pm 0.016$ & $22.08 \pm 2.08$ & $6.80 \pm 0.64$ & $3.29 \pm 0.31$ \\
\hline Niphargus hebereri (Croatia) $(\mathrm{n}=9)$ & $0.178 \pm 0.016$ & $23.12 \pm 2.08$ & $7.12 \pm 0.64$ & $3.45 \pm 0.31$ \\
\hline $\begin{array}{l}\text { Niphargus glennei } \\
\text { (British Islands) }(\mathrm{n}=4)\end{array}$ & $0.205 \pm 0.019$ & $26.62 \pm 2.47$ & $8.20 \pm 0.76$ & $3.97 \pm 0.37$ \\
\hline $\begin{array}{l}\text { Niphargus dobrogicus } \\
\text { (Romania: Dobrogea) }(\mathrm{n}=5)\end{array}$ & $0.217 \pm 0.019$ & $28.18 \pm 2.47$ & $8.68 \pm 0.76$ & $4.20 \pm 0.37$ \\
\hline $\begin{array}{l}\text { Niphargus irlandicus } \\
\text { (British Islands) }(\mathrm{n}=5)\end{array}$ & $0.247 \pm 0.020$ & $32.08 \pm 2.60$ & $9.88 \pm 0.80$ & $4.79 \pm 0.39$ \\
\hline
\end{tabular}



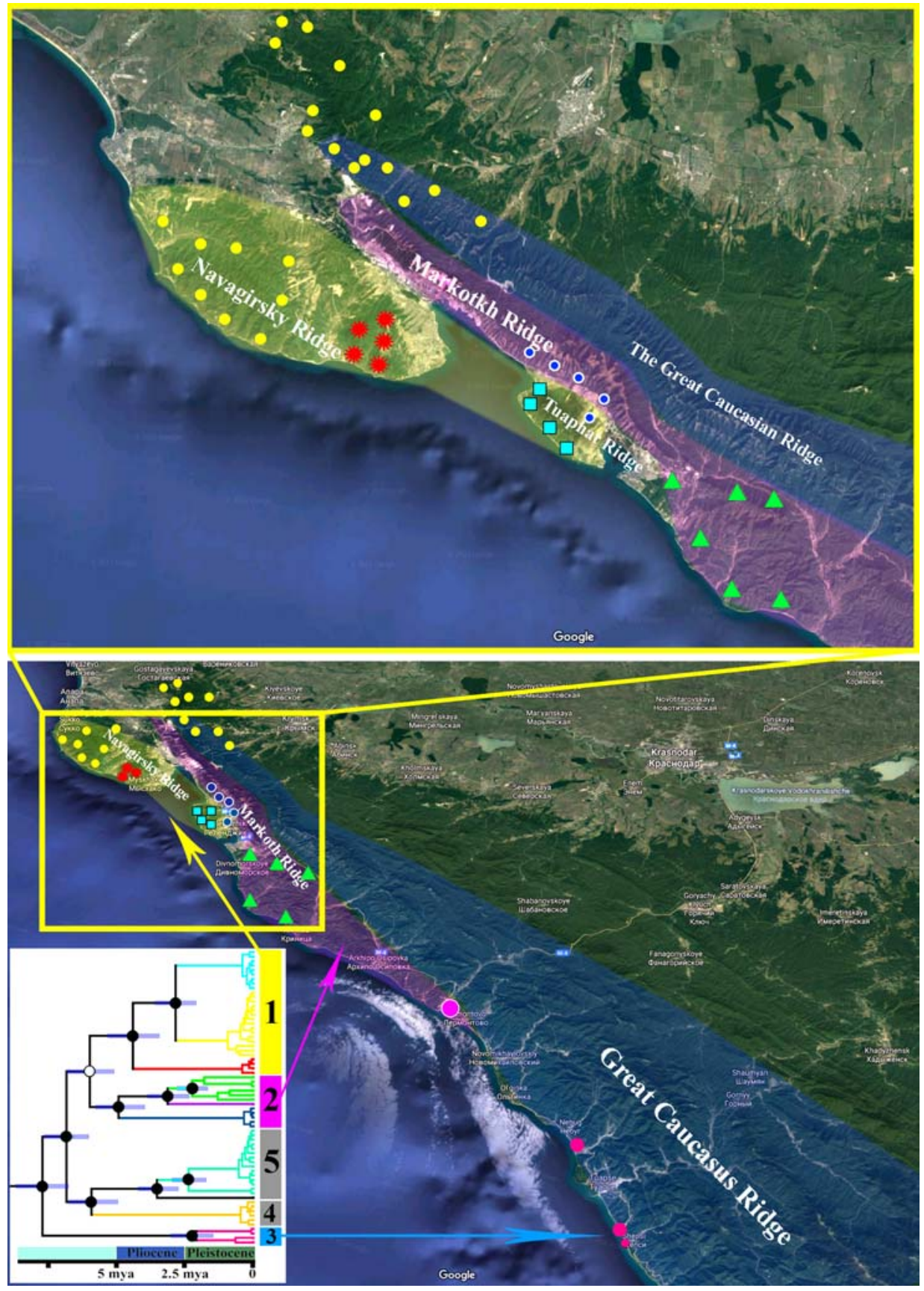

Fig. 3. The map of distribution of different lineages (species) of the Niphargus "tauricus" ingroup correlated with coastal mountain ridges in the foothills of the Great Caucasus (for color designations of the species see Fig. 1). 1 - Navagirsky-Tuaphat Ridges; 2 - Markotkh Ridge; 3 - Great Caucasian Ridge; 4 - Crimean Peninsula; 5 Romania.

Рис. 3. Карта распределения различных видов ингруппы Niphargus "tauricus" в привязке к прибрежным горным хребтам предгорий Большого Кавказа (цветовые обозначения видов см. Рис. 1). 1 - хребты Навагирский-Туапхат; 2 - хребет Маркотх; 3 - Большой Кавказский хребет; 4 - Крымский полуостров; 5 - Румыния. 
Mya (Table 2). At the same time, the estimated divergence time calculated using $p$-distances (see Table 2) are mostly linear and do not correspond to time-calibrated phylogenetic models (e.g., McInerney et al., 2014), but they also confirm the separation of the "tauricus" ingroup from European relatives by at least 6 Mya.

\section{Taxonomic part}

\author{
Order Amphipoda Latreille, 1816 \\ Family Niphargidae Bousfield, 1977 \\ Genus Niphargus Schiödte, 1849 \\ Niphargus "tauricus" ingroup
}

DIAGNOSIS. Head without pigmented spots on anterior lobe. Posteroventral corners of epimeral plates $I-I I I$ nearly right-angled, slightly rounded. Urosomite I with 1 spine accompanied by 1 simple seta on each side. Urosomite II with 3 spines on each side. Dactyli of pereopods III$V I I$ with small additional spine. Rami of uropod I of nearly equal length in both sexes. Uropod III in males with long exopodite, including distal article almost eual to proximal article, usually overreaching the length of antennas. Pleopods with 2 coupling hooks in retinacula. Telson with 3 medium distal spines and 1-2 lateral spines, accompanied by 2 plumose setae on each side; dorsal surface with 1 small or medium dorsal submarginal spine on each side.

INCLUDED SPECIES. Niphargus tauricus Birštein, 1964, N. dancaui Brad, Fišer, Flot et Sarbu, 2015, N. utrishensis Marin et Palatov sp.n., N. novorossicus Marin et Palatov sp.n., $N$. alisae Marin, Krylenko et Palatov sp.n., $N$. ashamba Marin, Krylenko et Palatov sp.n., N. malakhovi Marin et Palatov sp.n., N. dederkoyi Marin et Palatov sp.n.

\section{Niphargus tauricus Birštein, 1964}

Figs 4A; 5-8; 33A.

MATERIAL EXAMINED. NEOTYPE, $\sigma^{7}$ (bl. $8.0 \mathrm{~mm}$ ) (ZMMU Mb-1182), RUSSIA, Crimean Peninsula, Crimean Republic, Yalta Urban area, southwest spurs of Ai-Petri Plateau, vicinity of the village of Oliva, Oliva (Kovako)
Spring, $44^{\circ} 25^{\prime} 11.4^{\prime \prime} \mathrm{N}, 33^{\circ} 51^{\prime} 36.48^{\prime \prime} \mathrm{E}$, about 336 meter above the sea level ( $m$ a.s.1.), hand net sampling, coll. I. Marin \& V. Maslova, 12.10. 2018.

ADDITIONAL MATERIAL. $10^{7}, 1$ 积 (ZMMU Mb-1183), 10', 5우 (bl. 4.0-7.0 mm) (LEMMI), same locality and data as neotype; $20^{7} \bigcirc^{7}, 2$, +9 (bl. 4.0-7.0 mm) (LEMMI), a small spring near the old Yalta-Sevastopol road close to the Shaitan-Merdven Pass, $44^{\circ} 25^{\prime} 04.1^{\prime \prime} \mathrm{N}$, $33^{\circ} 51^{\prime} 46.6^{\prime \prime} \mathrm{E}$, about $273 \mathrm{~m}$ a.s.1., in a small spring, hand net sampling, coll. I. Marin \& V. Maslova, 12.10.2018.

DESCRIPTION.

BODY: depigmented, moderately slender.

HEAD (Fig. 4A): length is approximately 9 and $11 \%$ of body length in males and in males and females, respectively; rostrum and pigmented spots on anterior lobe absent, with subrounded lateral cephalic lobes and excavated anteroventral sinus.

PEREON: pereonites I-VII without setae, smooth.

PLEOSOMA: pleonites I-III with several short marginal setae on each posterodorsal margin.

EPIMERAL PLATES: posteroventral corners of epimeral plates I-III nearly right-angled, slightly rounded (Fig. 8A-C). Epimeral plate I: posterior and ventral margin slightly convex; without spines along ventral margin; with 4 setae along posterior margin; posteroventral angle with 1 strong seta. Epimeral plate II: posterior margin straight, ventral margin convex; with 2 spiniform setae along ventral margin; 5 setae along posterior margin; posteroventral angle with 1 strong seta. Epimeral plate III: posterior margin slightly concave, ventral margin convex; with 2-3 spiniform setae along ventral margin; with 5 setae along posterior margin; posteroventral angle with 2 strong seta of different sizes.

UROSOMITES (Fig. 33A): urosomite I with 1 long simple seta on each side dorsolaterally, with 1 posteroventral spines near basis of uropod I dorsolaterally; urosomite II with 1 simple strong spine accompanying 1 simple seta on each side dorsolaterally; urosomite III unarmed. 

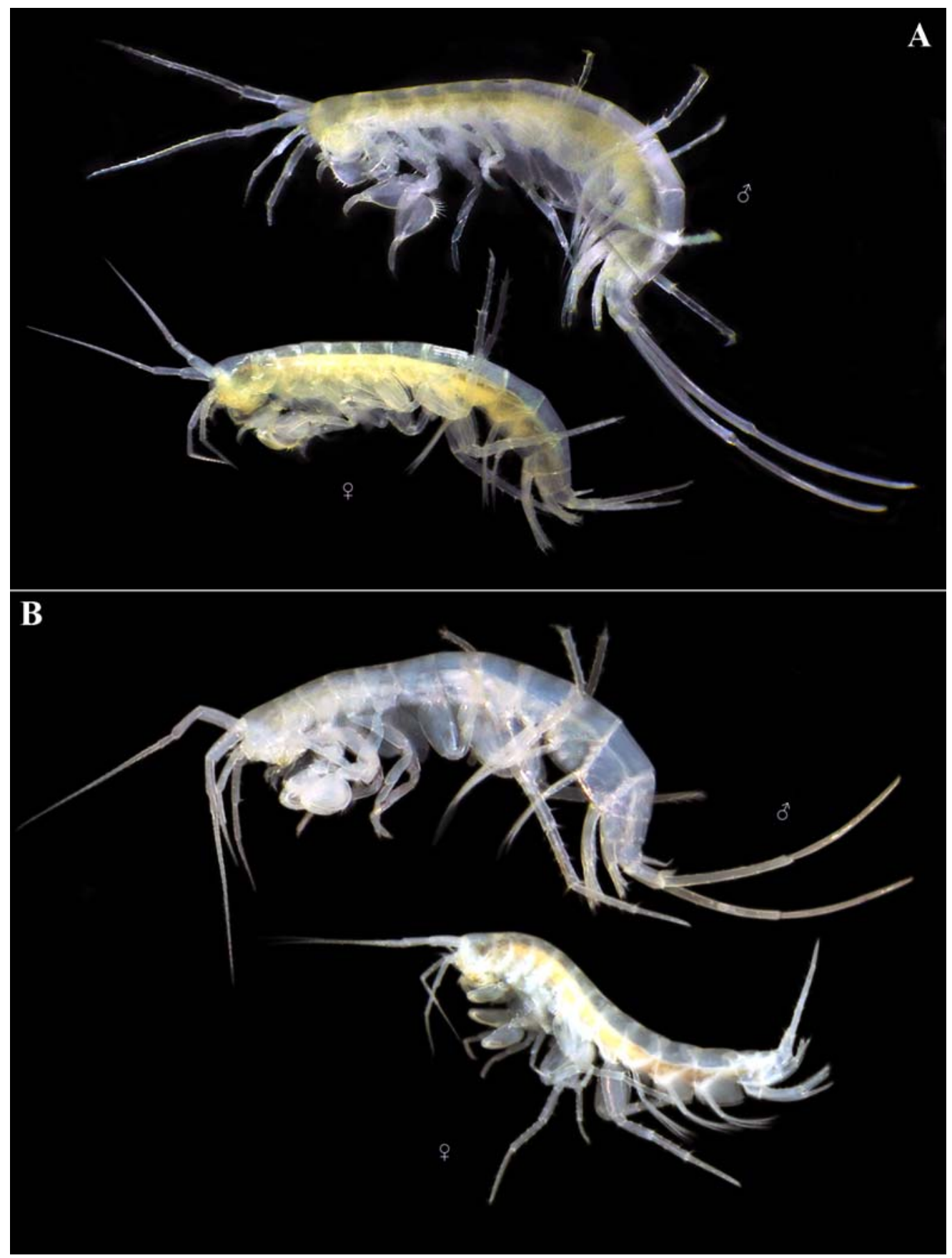

Fig. 4. General view and live coloration of Niphargus tauricus Birštein, 1964 (A) and N. utrishensis sp.n. (B). Long exopodite of uropod III in males, exceeding the length of the antennae, is the distinctive feature of the "tauricus" ingroup.

Рис. 4. Общий вид и окраска живых особей Niphargus tauricus Birštein, 1964 (А) и N. utrishensis sp.n. (B). Длинный экзоподит уропода III у самцов, превышающий длину антенн, является отличительной особенностью ингруппы "tauricus". 


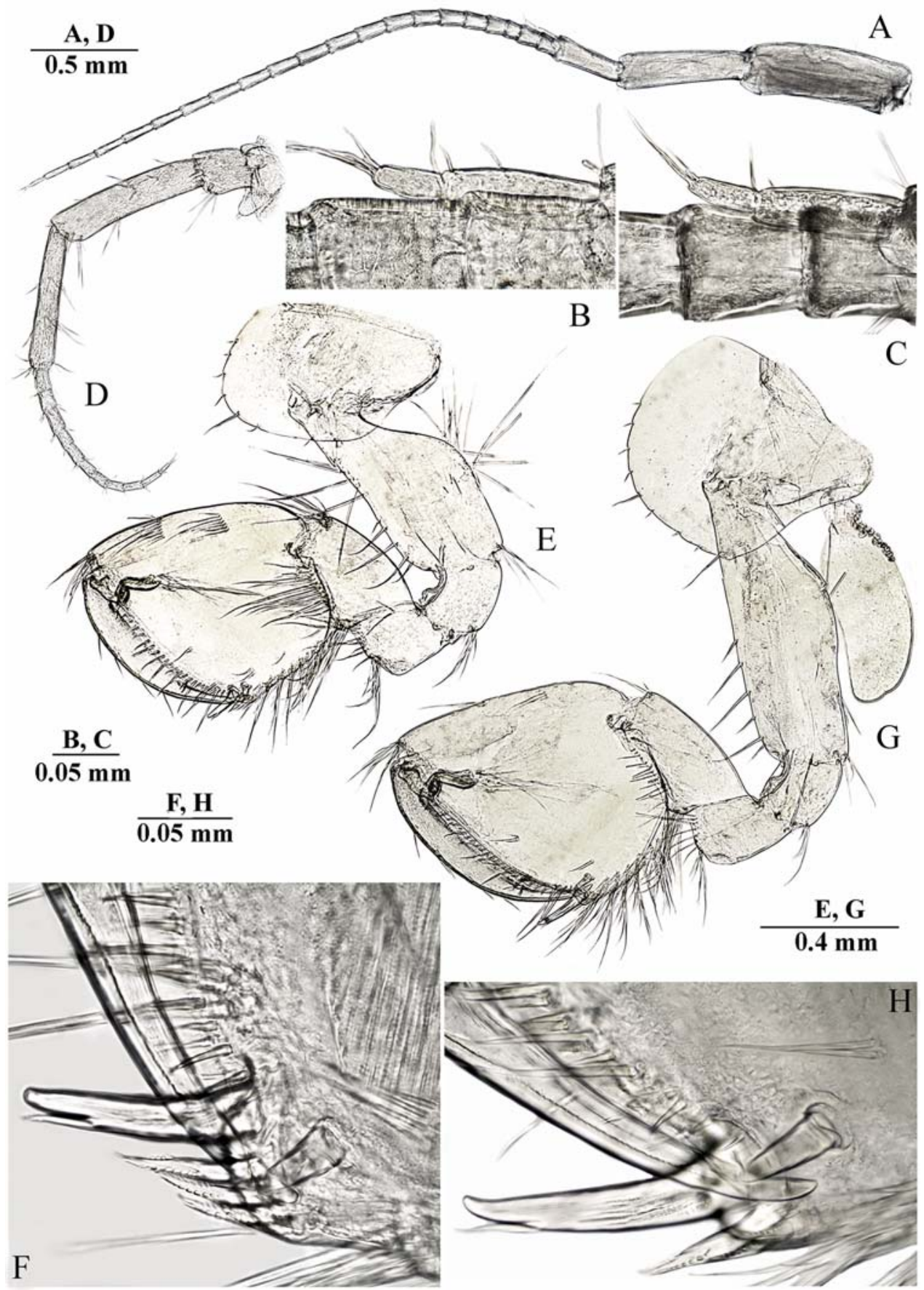

Fig. 5. Niphargus tauricus Birštein, 1964, O': A — antenna I; B, C - accessory flagellum of antenna I; D antenna II; E - gnathopod I; F - distoventral corner of chela of GnI; G - gnathopod II; H - distoventral corner of chela of GnII.

Pис. 5. Niphargus tauricus Birštein, 1964, ơ': А - антенна I; В, С - дополнительный жгутик антенны I; D — антенна II; E — гнатопод I; F — дистовентральный угол клешни GnI; G — гнатопод II; H дистовентральный угол клешни GnII. 


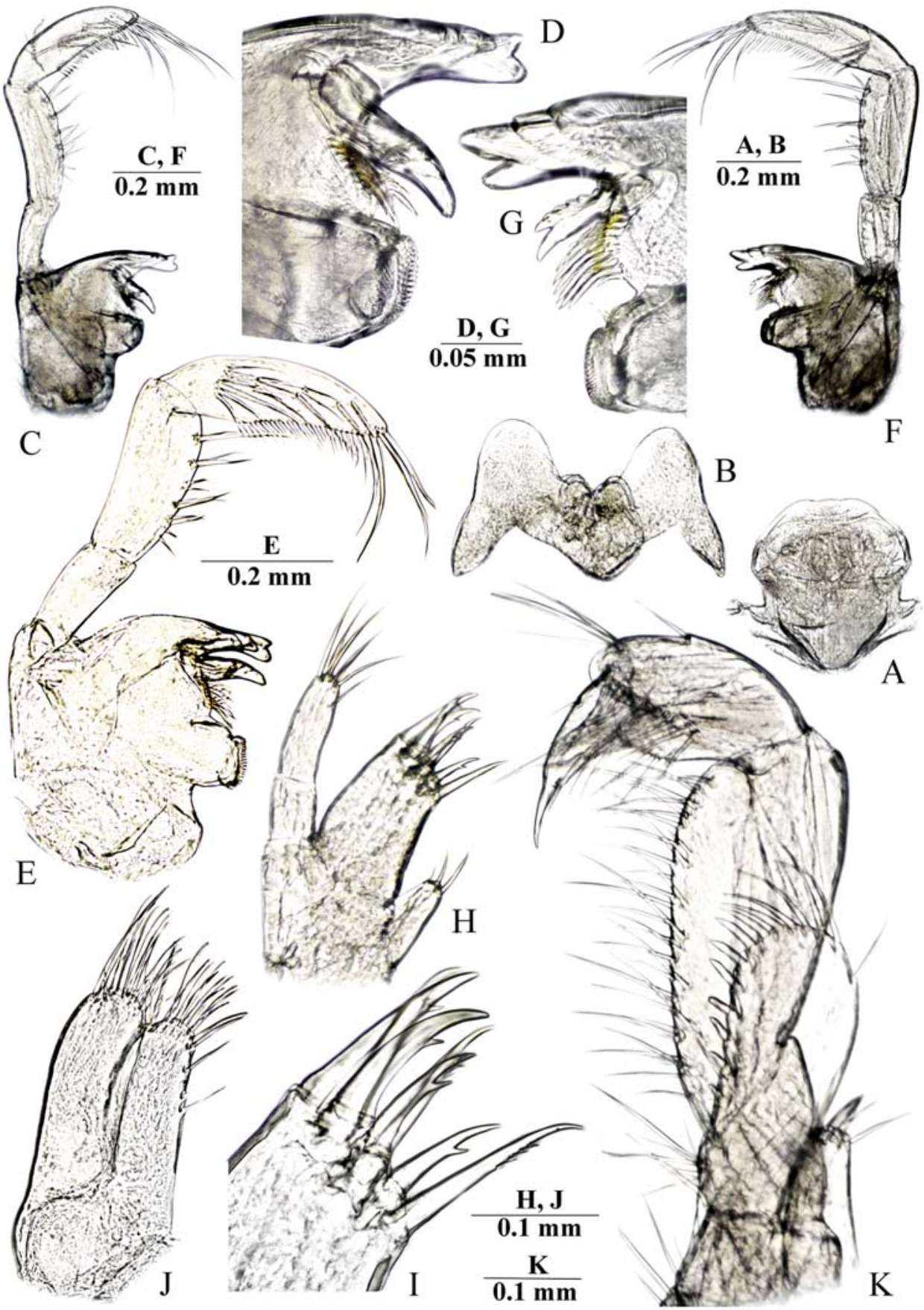

Fig. 6. Niphargus tauricus Birštein, 1964, O': A - labrum (upper lip); B — labium (lower lip); C, E, F mandible; D, G - incisor process and pars incisiva of mandible; H - maxilla I; I - same, distal margin of outer lobe; J - maxilla II; $\mathrm{K}$ - maxilliped.

Pис. 6. Niphargus tauricus Birštein, 1964, О7 : А — верхняя губа; В — нижняя губа; С, Е, F — мандибула; $\mathrm{D}, \mathrm{G}$ - режущий отросток и pars incisiva (резец) мандибулы; H — максилла I; I — то же, дистальный край наружной доли; J — максилла II; K - максиллипед. 


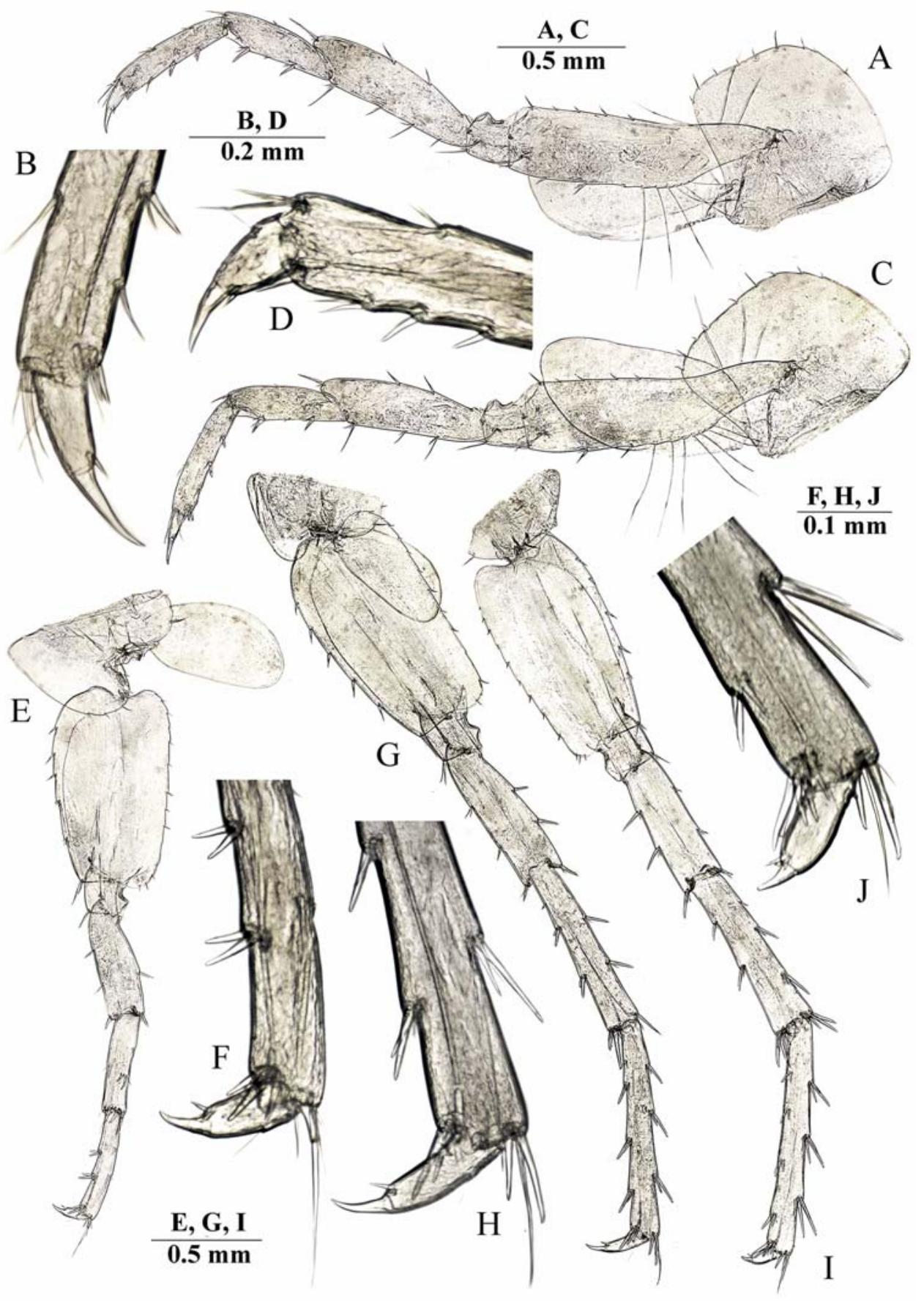

Fig. 7. Niphargus tauricus Birštein, 1964, O': A — pereopod III; B — dactylus of PIII; C - pereopod IV; D - dactylus of PIV; E - pereopod V; F - dactylus of PV; G - pereopod VI; H - dactylus of PVI; I pereopod VII; J - dactylus of PVII.

Рис. 7. Niphargus tauricus Birštein, 1964, O': А - переопод III. В - дактилус PIII; C - переопод IV; D — дактилус PIV; E — переопод V; F — дактилус PV; G — переопод VI; H - дактилус PVI; I переопод VII; J — дактилус VII. 
Euxinian relict amphipods in the subterranean fauna of the Northern Black Sea region 263

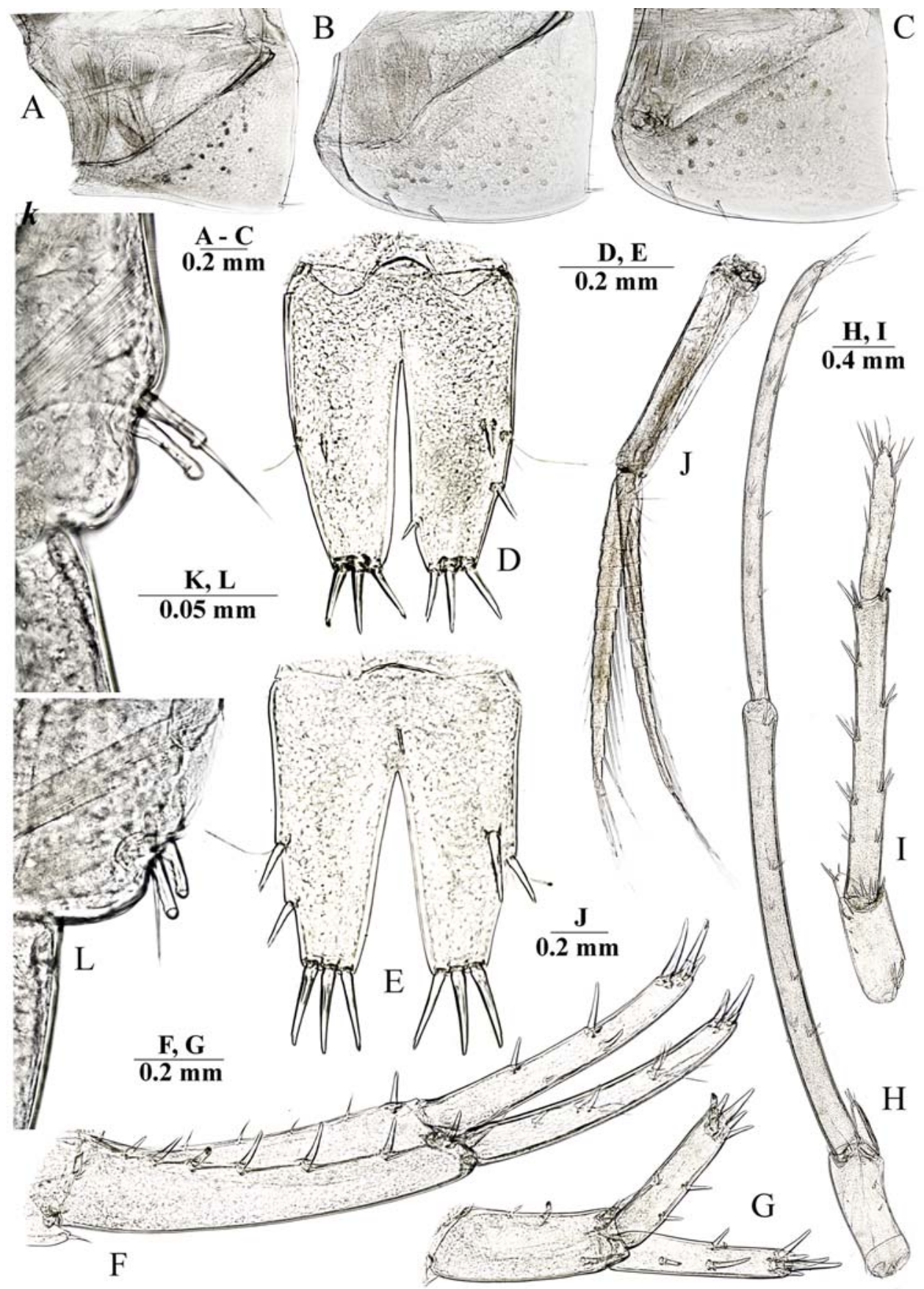

Fig. 8. Niphargus tauricus Birštein, 1964, O' (A-D, H, J-L) and 9 (E, I): A-C - epimeral plates I-III; D-E — telson; F — uropod I; G — uropod II; H-I — uropod III; J - pleopod III; K-L — retinacula of pleopod III.

Pис. 8. Niphargus tauricus Birštein, 1964, О (A-D, H, J-L) и 9 (E, I): А-C - эпимеральные пластинки I-III; D-E - тельсон; F — уропод I; G - уропод II; H-I — уропод III; J — плеопод III; $\mathrm{K}-\mathrm{L}$ ретинакула плеопод III. 
COXAE (Figs 5E, G; 7A, C, E, G, I): coxal plate I (Fig. 5E) irregular oval, with rounded anteroventral corner, armed with 6 setae; width/ depth ratio is $0.7-0.71$; width/depth ratio of coxal plates II-IV (Figs 5G; 7A, C) are 0.85/1, $1.03-1.04 / 1$ and $1 / 1.1$, respectively; anterior and ventral margins of coxal plates II-IV with 9 setae each; with rounded anteroventral corners; coxal plates V-VI (Fig. 7E, G) with large lobes anteriorly, posterior margins with 3 and 2 setae, respectively; anterior margins with 5 and 0 setae respectively; coxal plate VII trapezoid, with concave ventral margin; posterior lobe with 1 seta; coxal gills II-VI ovoid, length ratio of gills/bases of pereopods are $0.69-0.7 / 1,0.82$ $0.85 / 1,0.85 / 1,0.78 / 1$ and $0.56 / 1$, respectively.

ANTENNA I (Fig. 5A): slender, about 45\% of body length; peduncular articles moderately slender, ratio is $1 / 0.82 / 0.41$; flagellum with 21 articles, most of them with 2 short aesthetascs each; accessory flagellum short, 2-articulated (Fig. 5B, C); length ratio of antennas I/II is $1 /$ 0.56 .

ANTENNA II (Fig. 5D): peduncular articles moderately stout, with several long setae along ventral margin, dorsal setae shorter than inner ones; flagellum relatively short, consisting of 11 articles with relatively short setae; length ratio of peduncular articles $4 / 5$ is $1 / 0.87$; flagellum is 0.7 of the length of peduncular articles $4+5$.

LABRUM (upper lip) (Fig. 6A): typical.

LABIUM (lower lip) (Fig. 6B): with entire, subrounded outer lobes and well-developed smaller inner lobes.

MANDIBLE (Fig. 6C-G): Left mandible: incisor process with 5 teeth, lacinia mobilis with 4 teeth; with row of 8 serrated setae between lacinia and molar process, few spatulate setae and 1 long seta at base of molar (Fig. 6D); mandibular palp article $2 / 3$ (distal) ratio is $1 / 1-$ 1.23; proximal article of palp without setae; article 2 with 12 setae; distal article with group of 6 A-setae; 3 groups of B-setae; 26 D-setae and 5 E-setae (Fig. 6E). Right mandible: incisor process with 4 teeth, lacinia mobilis bifurcate, with row of 8 serrated setae between lacinia and molar process (Fig. 6G).
MAXILLA I (Fig. 6H): inner lobe with 3 distal setae, outer lobe with 7 robust spines (6 spines with 1 strong lateral tooth each, inner spine with 4 small lateral teeth (1-1-1-1-1-14) (Fig. 6I)); palp 2-articulated, distal article with 7 simple setae distally.

MAXILLA II (Fig. 6J): both plates with numerous long distal simple setae, outer lobe with row of fine setae along outer margin.

MAXILLIPED (Fig. 6K): inner plate short, with 2 distal robust setae intermixed with 4 distal simple setae; outer plate reaching half of palpal article 2 and bearing row of 15-16 distolateral spines and distal setae; palpal article 3 with 1 median and 1 distal bunches of setae at outer margin; palpal article 4 with 1 median seta at outer margin; nail shorter than pedestal, with seta near basis.

GNATHOPOD I (Fig. 5E): basis elongated, with distal part greatly expanded; ischium with group of 5-6 posterodistal setae; merus subquadrate, equal to ischium; carpus is 0.52 of length of basis and 0.5 of length of propodus, with single distal group of setae anteriorly, with transverse rows of setae along posterior margin and row of setae posterolaterally; propodus subtrapezoidal, setose, with 6-7 rows of setae at posterior margin, anterior surface with 2 groups of total 7-8 setae each in addition to anterodistal group of 6-7 setae, several groups of short setae on inner surface, palmar corner armed with long spiniform palmar seta, 3-4 serrated spiniform setae, single supporting spiniform seta on inner surface (Fig. 5F); dactylus with 5 setae along anterior margin, with row of short setae along inner surface; length of nail is 0.23 of total length of dactylus.

GNATHOPOD II (Fig. 5G): basis width/ length is $0.33 / 1$, with 7 dorsolateral setae; ischium with 5 posterodistal setae; merus subquadrate, equal to ischium; carpus is 0.46 of length of basis and 0.57 of length of propodus, with distal group of setae anteriorly, few transverse rows of setae along posterior margin and row of setae posterolaterally; propodus subtrapezoidal, setose, larger than propodus (palm) of GnI (GnI/II as $0.85 / 1$ ), posterior margin with $7-8$ rows of setae, anterior surface with 2 group setae in 
addition to 7-8 anterodistal setae, with several groups of setae on inner surface, palmar corner with 1 strong palmar spiniform seta, single supporting spiniform seta on inner surface and 2 denticulated thick spiniform setae on outer side (Fig. 5H); dactylus with 4 setae along anterior surface and few short setae along inner surface; length of nail is about 0.23 of total length of dactylus.

PEREOPODS III-IV (Fig. 7A, C): almost similar in size and shape; basis is 3.7-3.9 times as long as wide, with posterior margin bearing long marginal setae, with distoventral group of setae; ischium short, subquadrate, with distoventral group of setae; merus with slender simple setae along anterior and posterior surfaces; carpus/propodus ratio is $0.90-0.95$; propodus with 4 groups of spines along ventral margin; dactylus (Fig. 7B, D) relatively stout, curved, sharp distally, with 1 small additional posterior median spine and 1 median short plumose seta at outer margin; dactyli ratio of PpIII/IV is $0.95 / 1$; length of nail is $0.44-0.46$ of total length of dactylus.

PEREOPODS V-VII (Fig. 7E-J): length ratio of $\mathrm{PpV} / \mathrm{VI} / \mathrm{VII}$ is $1 / 1.55 / 1.63$; length of PVII is about half of total body length.

PEREOPOD V (Fig. 7E): length/width ratio of basis is $1 / 0.58$, almost rectangular, with explicit posteroventral lobe; with facial setae; posterior margin almost straight with row of 14 slender marginal setae; anterior margin convex, with row of 5 slender marginal setae, which are distinctly longer than posterior ones, and group of setae in distal part; ischium subquadrate; merus with 2 bunches of slender spines along anterior surface and with 1 spine on posterior surface; carpus about as long as merus; propodus slender, 5.8-6 times as long as wide, with several bunches of short spines; dactylus (Fig. 5F) with 1 small additional posterior median spine and 1 median short plumose seta at outer margin.

PEREOPOD VI (Fig. 7G): length/width ratio of basis is $1 / 0.51$, with distinct posteroventral lobe and straight posterior margin bearing row of 14 short marginal setae; ischium with facial setae, anterior margin convex, with row of 5 longer marginal setae; merus with several bunches of short spines along anterior and posterior surfaces; carpus with group of spines intermixed with single short setae; propodus slender, about 7.6 times as long as wide, with several group of short spines; dactylus (Fig. $7 \mathrm{H}$ ) slender, with 1 small additional posterior median spine and 1 short median plumose seta at outer margin.

PEREOPOD VII (Fig. 7I): length/width ratio of basis is $1 / 0.51$, with distinct posteroventral lobe and convex posterior margin bearing row of 12 short marginal setae; with facial setae; anterior margin convex, with row of 5 longer marginal setae; ishium about as long as wide; merus with several bunches of short spines along anterior and posterior margins; carpus with 3 groups of short spines along anterior and 2 groups along posterior margins; propodus slender, about 7.8 times as long as wide, with several groups of short spines; dactylus (Fig. 7J) with 1 median spine and 1 seta at inner margin, and 1 short median plumose seta at outer margin.

PLEOPODS (Fig. 8J): pleopod I with basal segment bearing 1-2 simple setae, with 2 coupling hooks in retinacula; pleopod II with basal segment bearingout setae, with 2 coupling hooks in retinacula; pleopod III with basal segment bearing 3 small and medium-sized simple setae and 2 coupling hooks accompanied by 1 large simple seta in retinacula (Fig. $8 \mathrm{~K}-\mathrm{L}$ ).

UROPOD I (Fig. 8F): protopodite longer than rami, 4.4 times as long as wide, with dorsointernal row of 4 median setae and 1 subdistal spine, and dorsoexternal row of 6 spines; rami straight and subequal in length both in males and females, endopodite not paddle-like, with 2 dorsolateral, 2 small mesial and 4 apical spines; exopodite with 2 mesial groups consisting of single spines accompanying by several (2-4) simple setae and also 1-2 single dorsolateral spines and 4 apical spines.

UROPOD II (Fig. 8G): protopodite 1.5 times as long as wide, slightly shorter than rami; rami with lateral, mesial and distal slender spines, endopodite with 2 spines ventrolaterally, 1 spines mesially and 5 spines apically; exopodite with 1 spines dorsolaterally, 2 spines mesially and 5 
spines apically; length of exopodite/endopodite is $1 / 1.09$.

UROPOD III (Fig. 8H-I): different in males and females, about $0.68-0.7$ of body length in males and 0.32 in females. Male: protopodite 2.7 times as long as wide, with 2 lateral setae and 5-7 apical spiniform setae; rami unequal, endopodite short, about 15-16 times shorter than exopodite, with 1 small seta laterally and 3 setae apically, including at least 1 spiniform and 1 plumose setae; distal article is 0.96 of length of proximal article, with 6 groups of thin-flexible setae along each margin and group of simple setae apically; proximal article with 5 groups of thin-flexible, plumose and spiniform setae along inner and outer margins. Female: protopodite 2.1-2.2 times as long as wide, with 2 lateral setae and 5 apical spiniform setae; rami unequal, endopodite short, about 9.8-10 times shorter than exopodite, without seta laterally and 3 setae apically, including at least 1 spiniform and 1 plumose seta; distal article is 0.5 of length of proximal article, with 4 groups of thinflexible setae along each margin and group of simple setae apically; proximal article with 3-4 groups of spiniform setae along outer margin and 4-5 groups of thin-flexible and spiniform setae along inner margin.

TELSON (Fig. 8D-E): length/width ratio is $1 / 0.77-0.80$; cleft is $0.66-0.70$ of length of telson; margins straight or weakly rounded, narrowing apically; with variable armature, including 3 medium distal spines on each lobe and 12 lateral spines, accompanied by 2 plumose setae on each side; dorsal surface with 1 small or medium submarginal spine on each side and 12 small mesial setae; apical spiniform setae are $0.22-0.26$ of length of telson.

COLORATION. Body, appendages and internal organs are whitish or yellowish characteristic of stygobiotic representatives of the genus (Fig. 4A).

BODY SIZE. The largest collected 9 has tbl. $7.0 \mathrm{~mm}$; the largest collected $\sigma^{7}$ has tbl. $8.0 \mathrm{~mm}$.

GENBANK (NCBI) ACCESSION NUMBERS. KR905823, MZ382406, MZ382407.

TAXONOMIC REMARKS. The species can be clearly separated from related species of the "tauricus" ingroup (see Table 1) by 1) relatively short antenna I with 21 articles (vs. 26-28 articles in other species); 2) the longest distal article of uropod III in females with distal/ proximal article ratio is about $0.5 ; 3$ ) the shortest protopodite of uropod II with length/width ratio is about 1.5 ; 4) mostly quadrate propodus of gnathopod I with width/depth ratio is about 0.97 ; and 5) almost equal merus/carpus/propodus ratio of pereopod $\mathrm{V}$, which is about $1 / 1 / 1$. Moreover, Niphargus tauricus is the only species of the "tauricus" ingroup presently known from the Crimean Peninsula.

ECOLOGY AND DISTRIBUTION. A strictly endemic species that lives in several nearby springs and observation wells at an altitude of about 350-340 $\mathrm{m}$ a.s.1. on the southern slope of the Crimean Mountains. The main sampling resource was the Oliva (Kovako) Spring (44 $25^{\prime} 11.4^{\prime \prime} \mathrm{N}, 33^{\circ} 51^{\prime} 36.48^{\prime \prime} \mathrm{E}$, about $336 \mathrm{~m}$ a.s.1.), where the species is common and abundant, and we assume that the species also inhabits several observation wells located lower down the slope. The species is found only inside the spring and its probable lower course (another small spring, $44^{\circ} 25^{\prime} 04.1^{\prime \prime} \mathrm{N}, 33^{\circ} 51^{\prime} 46.6^{\prime \prime} \mathrm{E}$ ), where it is probably able to live for a long time, under the fallen leaves and rocks. No individuals of this species were found in the permanent and temporary reservoirs in this area.

\section{Niphargus utrishensis Marin et Palatov sp.n.} Figs 4B; 9-12; 33B.

MATERIAL EXAMINED. HOLOTYPE, $\sigma^{7}$ (bl. 8.0 mm) (ZMMU Mb-1184), RUSSIA, Krasnodar Krai, Anapa Urban area, SE part of Navagirsky Ridge, Utrish State Nature Reserve, Mokraya Schel, $44^{\circ} 41.653^{\prime} \mathrm{N}, 37^{\circ} 30.92^{\prime} \mathrm{E}$, about $127 \mathrm{~m}$ a.s.1., spring in the ravine of the Mokraya Schel, hand net sampling, coll. I. Marin, D. Palatov \& V. Maslova, 2.05.2019. PARATYPES, 19 (dissected) (bl. 7.0 mm) (ZMMU Mb-1185); $30^{7} \sigma^{7}, 4$ 우 (bl. 5.0-7.0 mm) (ZMMU Mb-1186), same data and locality as holotype.

ADDITIONAL MATERIAL. RUSSIA, Krasnodar Krai, SE part of Navagirsky Ridge, ANAPA URBAN AREA: $3 \sigma^{\top} \sigma^{\top}, 3 \circ \circ$ (LEM- 
MI), surrounding area of Gai-Kodzor village, $44^{\circ} 49.852^{\prime} \mathrm{N}, 37^{\circ} 24.707^{\prime} \mathrm{E}$, in a small spring, coll. I. Marin \& S. Marina, 7.05.2021; UTRISH STATE NATURE RESERVE: $20^{\top} 0^{\top}, 9+9$ (LEMMI), Mokraya Schel, 444ㄴ $41.653^{\prime} \mathrm{N}$, $37^{\circ} 30.92^{\prime} \mathrm{E}$, about $127 \mathrm{~m}$ a.s.1., a small spring in the ravine of the Mokraya Schel, hand net sampling, coll. I. Marin \& D. Palatov, 19.04.2019; $50^{7} 0^{7}, 13$ 우 (LEMMI), Navagirskaya Schel, $44^{\circ} 42.951^{\prime} \mathrm{N}, 37^{\circ} 30.534^{\prime} \mathrm{E}$, about $120 \mathrm{~m}$ a.s.1., a small spring in the ravine of the Navagirskaya Schel, hand net sampling, coll. I. Marin \& D. Palatov, 2.05.2019; $10^{7}, 5$ ㅇ (LEMMI), 4446. $672^{\prime} \mathrm{N}, 37^{\circ} 28.96^{\prime} \mathrm{E}$, about $130 \mathrm{~m}$ a.s.l., a small spring in the ravine of the Malaya Pilnya River, hand net sampling, coll. I. Marin \& D. Palatov, 4.05.2019; $10^{\top 7}, 4$ 우 (LEMMI), $44^{\circ} 47.357^{\prime} \mathrm{N}$, $37^{\circ} 28.299^{\prime} \mathrm{E}$, about $71 \mathrm{~m}$ a.s.1., a small spring in the valley of the Sukko River, hand net sampling, coll. I. Marin \& D. Palatov, 4.05.2019; $10^{7}, 2+0$ (LEMMI), Vodopadnaya Schel, $44^{\circ}$ $45^{\prime} 55.5^{\prime \prime} \mathrm{N} 37^{\circ} 25^{\prime} 16.7^{\prime \prime} \mathrm{E}$, about $220 \mathrm{~m}$ a.s.1., a small spring in the ravine of the Vodopadnaya Schel, hand net sampling, coll. I. Marin et D. Palatov, 5.05.2019; NW slope of Navagirsky Ridge, ABRAU-DURSO AREA: $2 \sigma^{7} \sigma^{7}, 5$ 우 (LEMMI), Efremova (Efimova) Schel, 44 $43.087^{\prime} \mathrm{N}, 37^{\circ} 32.938^{\prime} \mathrm{E}$, about $86 \mathrm{~m}$ a.s.1., a small spring in the riverbed of the Durso River, hand net sampling, coll. I. Marin \& D. Palatov, 8.05.2019; $10^{7}, 3$ 우 (LEMMI), 44⒋93 ${ }^{\circ}{ }^{\prime} \mathrm{N}$, $37^{\circ} 35.83^{\prime} \mathrm{E}$, about $110 \mathrm{~m}$ a.s.1., a small spring in the riverbed of the Abrau River, hand net sampling, coll. I. Marin \& D. Palatov, 18.04.2019; $20^{7} \sigma^{7}, 3$ 우 (LEMMI), 445․ $639^{\prime} \mathrm{N}, 37^{\circ} 36$. 923'E, about $195 \mathrm{~m}$ a.s.1., $1.5 \mathrm{~km} \mathrm{NE}$ of the Natukhaevskaya village, inside s a small spring, hand net sampling, coll. I. Marin \& D. Palatov, 7.05.2019; $20^{7} \sigma^{7}, 4$, + (LEMMI), Abrau-Durso forest area, in a small spring, $44^{\circ} 43.158^{\prime} \mathrm{N}$, $37^{\circ} 33.981^{\prime}$ E, coll. I. Marin \& S. Marina, 5.05. 2021; KRYMSK URBAN DISTRICT: 1 ㅇ (LEMMI), $44^{\circ} 56.281^{\prime} \mathrm{N}, 37^{\circ} 36.944^{\prime} \mathrm{E}$, about $230 \mathrm{~m}$ a.s.1., $3.3 \mathrm{~km} \mathrm{NE}$ of the Natukhaevskaya village, inside spring, hand net sampling, coll. I. Marin \& D. Palatov, 7.05.2019; 4우 (LEMMI), $44^{\circ} 56.678^{\prime} \mathrm{N}, 37^{\circ} 37.131^{\prime} \mathrm{E}$, about $346 \mathrm{~m}$ a.s.1., $4.5 \mathrm{~km} \mathrm{NE}$ of the Natukhaevskaya village, in- side a small spring, hand net sampling, coll. I. Marin \& D. Palatov, 7.05.2019; 1 ( (LEMMI), $44^{\circ} 58.593^{\prime} \mathrm{N}, 37^{\circ} 35.147^{\prime} \mathrm{E}$, about $241 \mathrm{~m}$ a.s.l., the Makarenko spring, $7 \mathrm{~km}$ SE of the Gostagaevskaya village, hand net sampling, coll. I. Marin \& D. Palatov, 7.05.2019; 507 $\sigma^{7}, 6$ \% $\mathrm{MI})$, Gorniy village, $44^{\circ} 53.123^{\prime} \mathrm{N}, 37^{\circ} 42.25^{\prime} \mathrm{E}$, in a small spring flowing in the Kudako River, coll. I. Marin \& S. Marina, 2.05.2021; $2 \sigma^{\top} \sigma^{\top}$, 4우으 (LEMMI), Verhnebakanskiy District, $44^{\circ} 52.698^{\prime} \mathrm{N}, 37^{\circ} 40.608^{\prime} \mathrm{E}$, a small spring in the upper reaches of the Psebeps River, coll. I. Marin \& S. Marina, 2.05.2021; $10^{7}, 2$, +9 (LEM$\mathrm{MI}), 44^{\circ} 52.7^{\prime} \mathrm{N}, 37^{\circ} 40.299^{\prime} \mathrm{E}$, a small spring in the upper reaches of the Psebeps River, coll. I. Marin \& S. Marina, 2.05.2021; 3 + (LEMMI), Gladkovskay village, $44^{\circ} 59.077^{\prime} \mathrm{N}, 37^{\circ} 42.07^{\prime} \mathrm{E}$, a spring in the lower reaches of the Psebeps River, coll. I. Marin \& D. Palatov, 7.05.2019; 3 우 (LEMMI), 445․ $585^{\prime} \mathrm{N}, 37^{\circ} 41.118^{\prime} \mathrm{E}$, a small spring in the lower reaches of the Psebeps River, coll. I. Marin \& D. Palatov, 7.05.2019; $30^{7} \sigma^{\top}, 4$ 우우 (LEMMI), Verhnebakansky district, $44^{\circ} 51.902^{\prime} \mathrm{N}, 37^{\circ} 40.491^{\prime} \mathrm{E}$, a small spring on the territory of a small village, coll. I. Marin \& S. Marina, 2.05.2021; NOVOROSSIYSK URBAN AREA: $30^{7} \sigma^{7}, 2$ 우 (LEMMI), Raevskaya village, $44^{\circ} 51.736^{\prime} \mathrm{N}, 37^{\circ} 33.389^{\prime} \mathrm{E}$, in a small spring in the field, coll. I. Marin \& S. Marina, 7.05.2021; 2 우 (LEMMI), surrounding area of Niznebakanskaya village, $44^{\circ} 50$. $076^{\prime} \mathrm{N}, 37^{\circ} 49.631^{\prime} \mathrm{E}$, in a small spring in forest, coll. I. Marin \& S. Marina, 4.05.2021; 1 (LEMMI), Atakay, $44^{\circ} 48.033^{\prime} \mathrm{N}, 37^{\circ} 45.253^{\prime} \mathrm{E}$, in hyporhean part of the forest spring, coll. I. Marin \& S. Marina, 4.05.2021; GELENDZIK URBAN AREA: $40^{7} \sigma^{7}, 4$ 우 (LEMMI), Grushovaya Balka, $44^{\circ} 46.89^{\prime} \mathrm{N}, 37^{\circ} 52.044^{\prime} \mathrm{E}$, in hyporhea of the Bogogo River, coll. I. Marin \& S. Marina, 8.05.2021.

DESCRIPTION.

BODY: depigmented, moderately slender.

HEAD (Fig. 4B): the length is approximately $10 \%$ of body length; rostrum and pigmented spots on anterior lobe absent, with subrounded lateral cephalic lobes and excavated anteroventral sinus.

PEREON: pereonites I-VII without setae, smooth. 


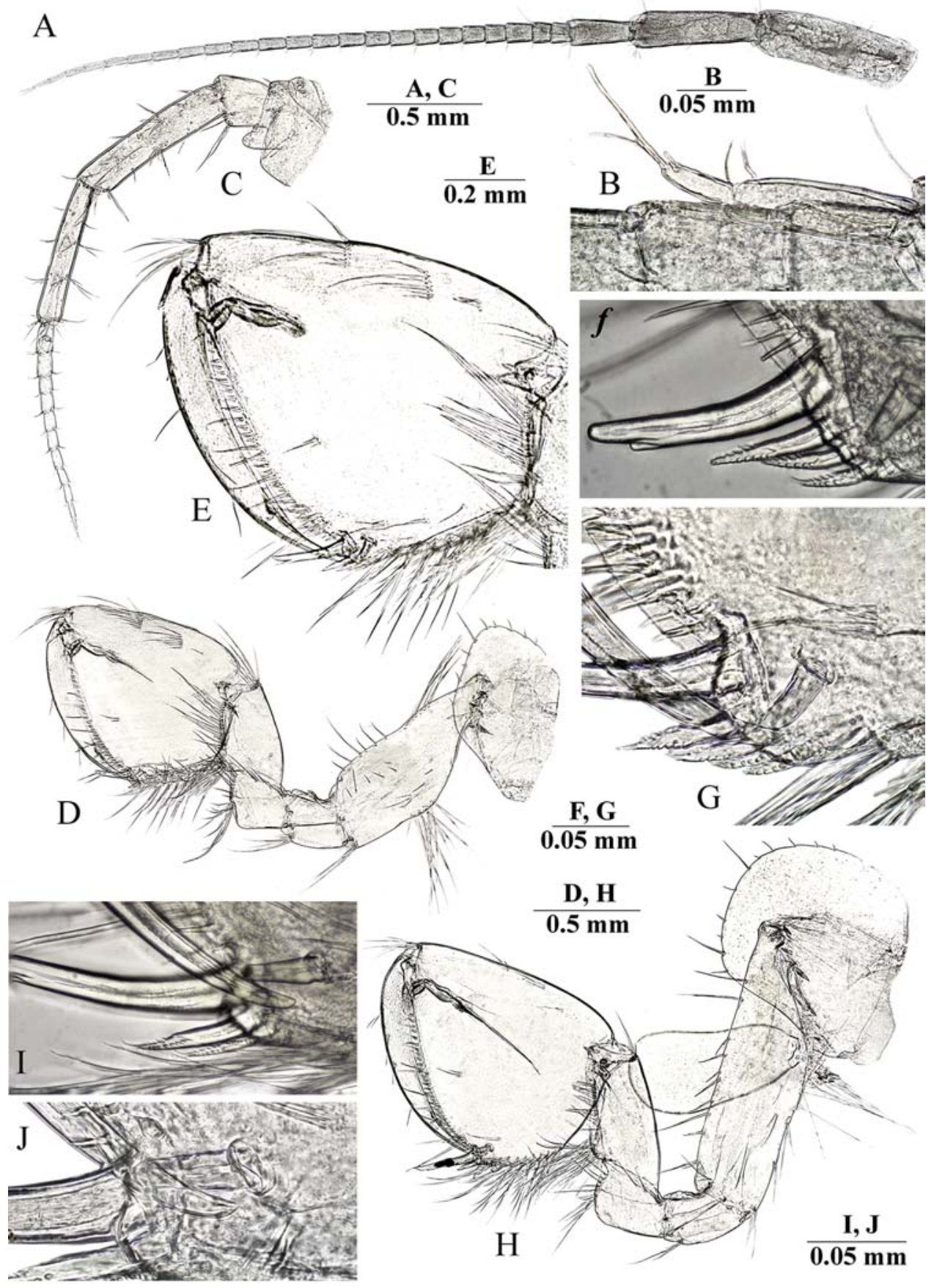

Fig. 9. Niphargus utrishensis sp.n., O': A — antenna I; B - accessory flagellum of antenna I; C - antenna II; D-E - gnathopod I; F-G - distoventral corner of chela of GnI; H - gnathopod II; I-J - distoventral corner of chela of GnII.

Рис. 9. Niphargus utrishensis sp.n., o': A — антенна I; В - дополнительный жгутик антенны I; C антенна II; D-E — гнатопод I; F-G - дистовентральный угол клешни GnI; H — гнатопод II; I-J дистовентральный угол клешни GnII. 


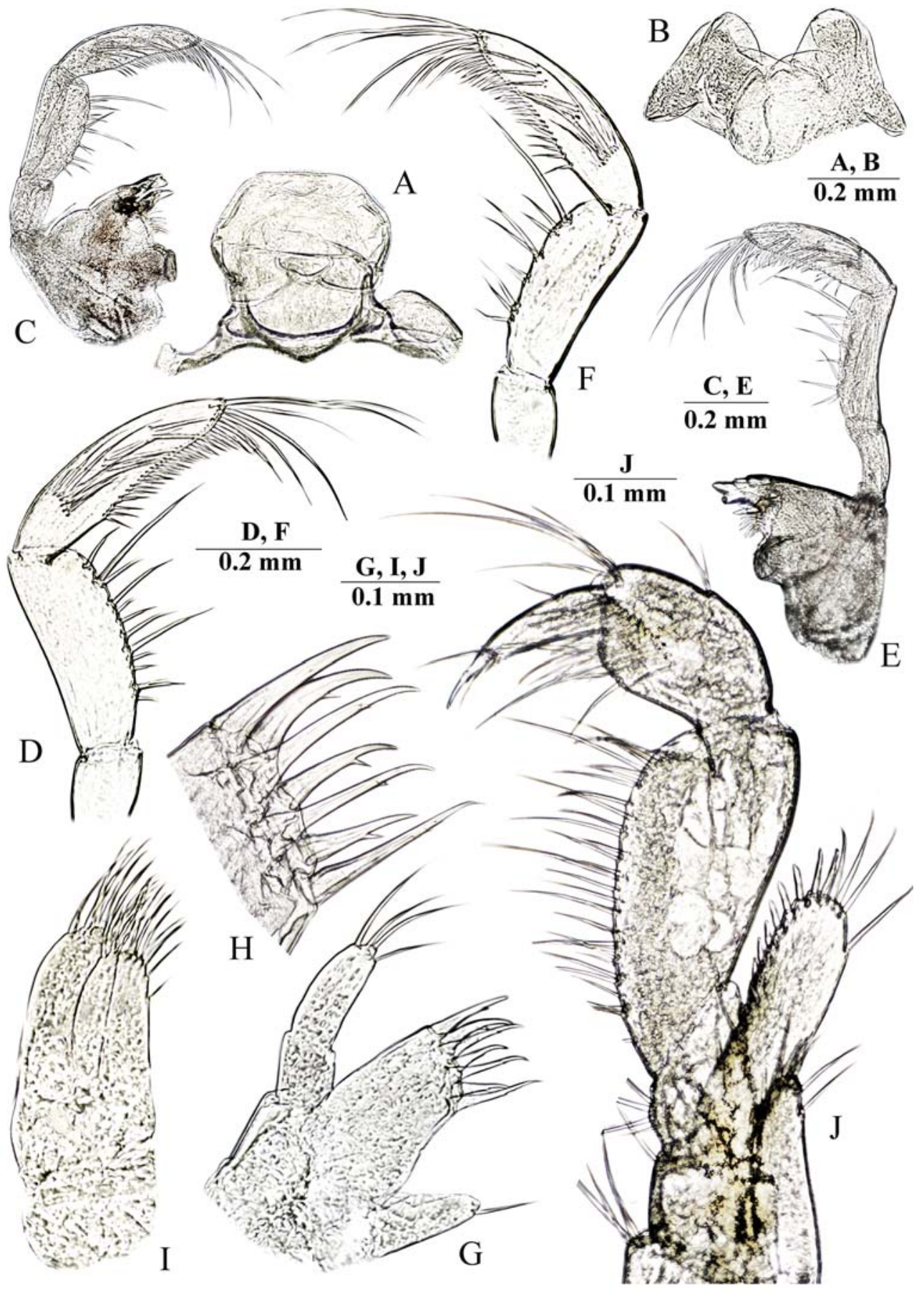

Fig. 10. Niphargus utrishensis sp.n., $\mathrm{O}^{\top}$ : A — labrum (upper lip); B — labium (lower lip); C-F — mandible; $\mathrm{G}$ - maxilla I; H - same, distal margin of outer lobe; I - maxilla II; J - maxilliped.

Рис. 10. Niphargus utrishensis sp.n., Oج: А — верхняя губа; В - нижняя губа; C-F - мандибула; $\mathrm{G}-$ максилла I; H — то же, дистальный край наружной доли; I — максилла II; J — максиллипед. 


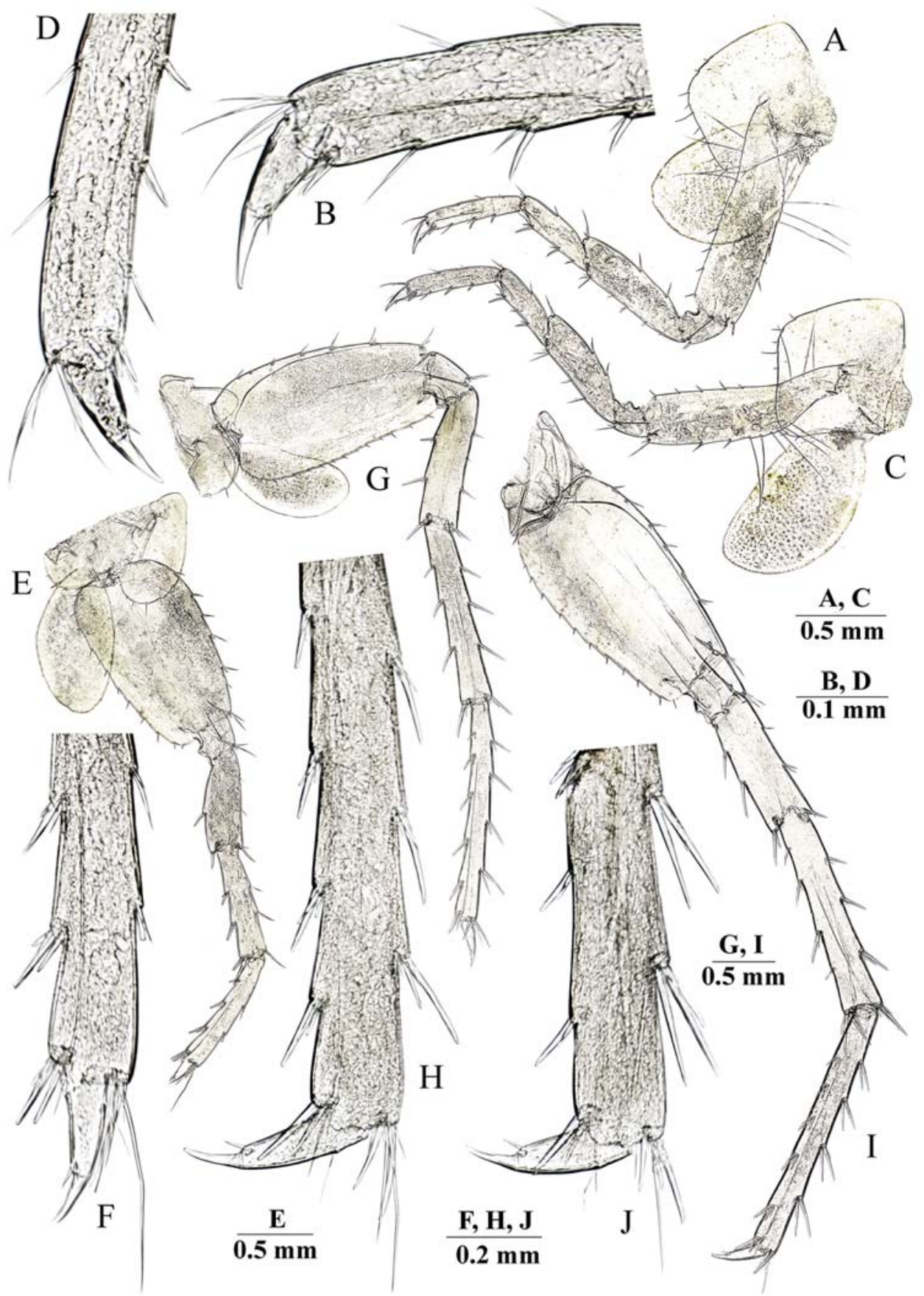

Fig. 11. Niphargus utrishensis sp.n., O': A — pereopod III; B — dactylus of PIII; C - pereopod IV; D dactylus of PIV; E - pereopod V; F - dactylus of PV; G - pereopod VI; H - dactylus of PVI; I pereopod VII; J - dactylus of PVII.

Рис. 11. Niphargus utrishensis sp.n., О': А - переопод III. В - дактилус PIII; C - переопод IV; D дактилус PIV; Е — переопод V; F - дактилус PV; G — переопод VI; H — дактилус PVI; I — переопод VII; J - дактилус VII. 
Euxinian relict amphipods in the subterranean fauna of the Northern Black Sea region 271

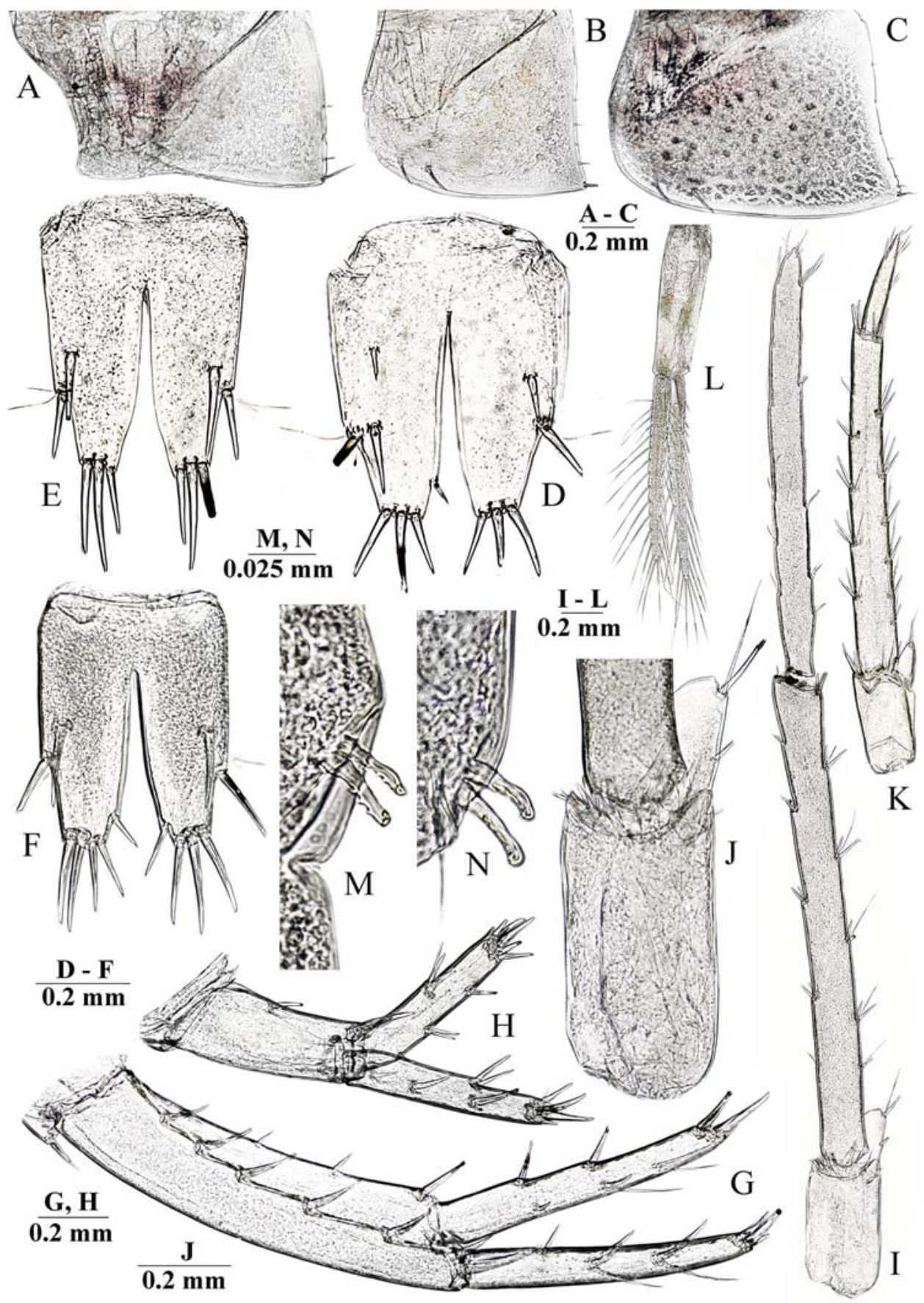

Fig. 12. Niphargus utrishensis sp.n., $\mathrm{O}^{\top}(\mathrm{A}-\mathrm{C}, \mathrm{E}-\mathrm{J}, \mathrm{L}-\mathrm{N})$ and $\odot$ (K, D): A-C - epimeral plates I-III; DF - telson; G - uropod I; H - uropod II; I-K - uropod III; L — pleopod III; M-N - retinacula of pleopod III.

Pис. 12. Niphargus utrishensis sp.n., О (А-C, E-J, L-N) и 9 (K, D): А-C - эпимеральные пластинки I-III; D-F — тельсон; G - уропод I; H - уропод II; I-K — уропод III; L — плеопод III; M-N ретинакула плеопод III. 
PLEOSOMA: pleonites I-III with several short marginal setae on each posterodorsal margin.

EPIMERAL PLATES (Fig. 12A-C): posteroventral corners of epimeral plates I-II nearly right-angled, slightly rounded; posteroventral corners of epimeral plates III bluntly shaped (Fig. 12C). Epimeral plate I: posterior and ventral margin slightly convex; without spines along ventral margin; with 3 setae along posterior margin; posteroventral angle with 1 strong seta. Epimeral plate II: posterior margin concave, ventral margin slightly convex; with 2 spiniform setae along ventral margin; 4 setae along posterior margin; posteroventral angle with 1 strong seta. Epimeral plate III: posterior margin distinctly concave, ventral margin slightly convex; with 2 spiniform setae along ventral margin; with 6 setae along posterior margin; posteroventral angle with 1 strong seta.

UROSOMITES (Fig. 33B): urosomite I with 1 spine accompanying 1 simple seta on each side dorsolaterally, with 1 posteroventral spines near basis of uropod I dorsolaterally; urosomite II with 3 simple strong spines on each side dorsolaterally; urosomite III unarmed.

COXAE (Figs 9D, H; 11A, C, E, G, I): coxal plate I oval, with rounded anteroventral corner, armed with 11 setae; width/depth ratio is $0.8 / 1$; width/depth ratio of coxal plates II-IV are 1/1, $1 / 1$ and $1 / 1.05$, respectively; anterior and ventral margins of coxal plates II-III with 11 setae each, anterior and ventral margins of coxal plates IV with 12 setae; with rounded anteroventral corners; coxal plates V-VI with large lobes anteriorly, posterior margins with 3 and 2 setae, respectively; anterior margins with 5 and 0 setae respectively; coxal plate VII trapezoid, with concave ventral margin; posterior lobe with 1 seta; coxal gills II-VI ovoid, gills/bases ratio of pereopods are $0.64 / 1,0.77 / 1,0.9 / 1,0.79-0.8 / 1$ and $0.6 / 1$, respectively.

ANTENNA I (Fig. 9A): slender, about 0.52 0.54 of body length; peduncular articles moderately slender, ratio is $1 / 0.82 / 0.43$; flagellum consisting of 23 articles, most of them with 2 short aesthetascs each; accessory flagellum short, 2articulated (Fig. 9B); antennas I/II ratio is 1/0.69.
ANTENNA II (Fig. 9C): peduncular articles moderately stout, with several long setae along ventral margin, dorsal setae shorter than inner ones; flagellum relatively short, consisting of 11 articles with relatively short setae; the length of peduncle articles $4 / 5$ is $1 / 0.88$; flagellum is 0.7 of the length of peduncular articles $4+5$.

LABRUM (upper lip) (Fig. 10A): typical.

LABIUM (lower lip) (Fig. 10B): with entire, subrounded outer lobes and well-developed smaller inner lobes.

MANDIBLE (Fig. 10C, E): left mandible: incisor process with 5 teeth, lacinia mobilis with 4 teeth; with row of 8 serrated setae between lacinia and molar process, few spatulate setae and one long seta at base of molar (Fig. 10C); mandibular palp article 2/3 (distal) ratio is $1 / 1-1.18$; proximal article of palp without setae; article 2 with 12 setae; distal article with group of 6 A-setae; 2 groups of B-setae; 24 Dsetae and 5 E-setae (Fig. 10D, F). Right mandible: incisor process with 4 teeth, lacinia mobilis bifurcate, with row of 8 serrated setae between lacinia and molar process (Fig. 10E).

MAXILLA I (Fig. 10G): inner lobe with 2 distal setae, outer lobe with 7 robust spines (6 spines with 1 strong lateral tooth each, inner spine with 3 small lateral teeth (1-1-1-1-1-13) (Fig. 10H)); palp 2-articulated, distal article with 6 simple setae distally.

MAXILLA II (Fig. 10I): both plates with numerous long distal simple setae, outer lobe with row of fine setae along outer margin.

MAXILLIPED (Fig. 10J): inner plate short, with 2 distal robust setae intermixed with 5 distal simple setae; outer plate reaching half of palpal article 2 and bearing row of 16-17 distolateral spines and distal setae; palpal article 3 with 1 median and 1 distal bunches of setae at outer margin; palpal article 4 with 1 median seta at outer margin; nail shorter than pedestal, with seta near basis.

GNATHOPOD I (Fig. 9D-E): basis elongated, with distal part greatly expanded; ischium with group of 6-7 posterodistal setae; merus subquadrate, equal to ischium; carpus is 0.49 0.51 of length of basis and 0.50 of length of propodus, with single distal group of setae ante- 
riorly, with transverse rows of setae along posterior margin and row of setae posterolaterally; propodus subtrapezoidal, setose, with 8 rows of setae at posterior margin, anterior surface with 2 groups of total 7-8 setae each in addition to anterodistal group of 6-7 setae, several groups of short setae on inner surface, palmar corner armed with 1 long spiniform palmar seta, 4 serrated spiniform setae, single supporting spiniform seta on inner surface (Fig. 9F-G); dactylus with 4 setae along anterior margin, with row of short setae along inner surface; length of nail is 0.25 of total length of dactylus.

GNATHOPOD II (Fig. 9H): width/length ratio of basis is $0.30 / 1$, with 11 dorsolateral setae; ischium with 5 posterodistal setae; merus subquadrate, equal to ischium; carpus is 0.47 of length of basis and 0.59 of length of propodus, with distal group of setae anteriorly, few transverse rows of setae along posterior margin and row of setae posterolaterally; propodus subtrapezoidal, setose, larger than propodus of GnI ( $\mathrm{GnI} / \mathrm{II}$ as $0.92 / 1)$, posterior margin with 9 rows of setae, anterior surface with 2 group setae in addition to 8-9 anterodistal setae, with several groups of setae on inner surface, palmar corner with 1 strong palmar spiniform seta, single supporting spiniform seta on inner surface and 2 denticulated thick spiniform setae on outer side (Fig. 9I-J); dactylus with 5 setae along anterior surface and few short setae along inner surface; length of nail is about 0.27 of total length of dactylus.

PEREOPODS III-IV (Fig. 11A, C): almost similar in size and shape; basis is 3.7-3.9 times as long as wide, with posterior margin bearing long marginal setae, with distoventral group of setae; ischium short, subquadrate, with distoventral group of setae; merus with slender simple setae along anterior and posterior surfaces; carpus/propodus ratio is $0.87-0.91$; propodus with 3 groups of spines along ventral margin; dactylus (Fig. 11B, D) relatively stout, curved, sharp distally, with 1 small additional posterior median spine and 1 median short plumose seta at outer margin; dactyli ratio of PpIII/IV is $1.1 / 1$; the length of nail is $0.42-0.47$ of total length of dactylus.
PEREOPODS V-VII(Fig. 11E, G, I): length ratio of $\mathrm{PpV} / \mathrm{VI} / \mathrm{VII}$ is $1 / 1.33 / 1.30$; length of PVII is about half of total body length.

PEREOPOD V (Fig. 11E): length/width ratio of basis is $1 / 0.61$, almost rectangular, with distinct posteroventral lobe; with facial setae; posterior margin slightly convex, with row of 14 slender marginal setae; anterior margin convex, with row of 6 slender marginal setae, which are distinctly longer than posterior ones, and group of setae in distal part; ischium subquadrate; merus with 2 bunches of slender spines along anterior surface and with 1 spine on posterior surface; carpus about as long as merus; propodus slender, 5.8-6 times as long as wide, with several bunches of short spines; dactylus (Fig. $11 \mathrm{~F}$ ) with 1 small additional posterior median spine and 1 median short plumose seta at outer margin.

PEREOPOD VI (Fig. 11G): length/width ratio of basis is $1 / 0.51$, with facial setae, distinct posteroventral lobe and slightly concave posterior margin bearing row of 17 short marginal setae, anterior margin convex, with row of 6 longer marginal setae; merus with several bunches of short spines along anterior and posterior surfaces; carpus with group of spines intermixed with single short setae; propodus slender, about 9.7 times as long as wide, with several group of short spines; dactylus (Fig. 11H) slender, with 1 small additional posterior median spine and 1 short median plumose seta at outer margin.

PEREOPOD VII (Fig. 11I): Male: length/ width ratio of basis is $1 / 0.53$, with distinct posteroventral lobe and slightly convex posterior margin bearing row of 12 short marginal setae; with facial setae; anterior margin convex, with row of 6 longer marginal setae; carpus with 4 groups of short spines along dorsal and 3 along ventral margins; propodus slender, about 9.8 times as long as wide, with several groups of short spines; dactylus (Fig. 11J) with 1 median spine and 1 seta at inner margin, and 1 short median plumose seta at outer margin. Female: length/width ratio of basis is $1 / 0.59$, with distinct posteroventral lobe and distinctly convex posterior margin bearing row of 11 short mar- 
ginal setae; with facial setae; anterior margin convex, with row of 6 longer marginal setae; ishium about as long as wide; merus with several bunches of short spines along anterior and posterior margins; carpus with 3 groups of short spines along anterior and 2 groups along posterior margins; propodus slender, about 8.6 times as long as wide, with several groups of short spines; dactylus with 1 median spine and 1 seta at inner margin, and 1 short median plumose seta at outer margin.

PLEOPODS (Fig. 12L): pleopod I with basal segment armed with 2-3 simple setae and 2 coupling hooks in retinacula; pleopod II with basal segment armed with 1 simple seta and 2 coupling hooks in retinacula; pleopod III with basal segment armed with 2-4 small and medium-sized simple setae and 2 coupling hooks accompanied by 1 large simple seta in retinacula (Fig. 12m, $n$ ).

UROPOD I (Fig. 12G): protopodite longer than rami, 4 times as long as wide, with dorsointernal row of 4 median setae and 1 subdistal spine, and dorsoexternal row of 5 spines; rami straight and subequal in length both in males and females, endopodite not paddle-like, with 3 dorsolateral and 1 mesial spine accompanying by several (2-3) long simple setae, 4 apical spines; exopodite with 2 mesial groups consisting of single spines accompanying by several (2-4) simple setae and also 1-2 single dorsolateral spines, 4 apical spines.

UROPOD II (Fig. 12H): protopodite 2.6 times as long as wide, subequal rami; rami with lateral, mesial and distal slender spines, endopodite with 1 group consisting 2-3 spines dorsolaterally and 2-3 spines ventrolaterally, 6 spines apically; exopodite with 1 group consisting 2-3 spines dorsolaterally, 3 single spines mesially and 5 apically; exopodite/endopodite ratio is $1 / 1.15$.

UROPOD III (Fig. 12I-K): different in males and females, about 0.6 of body length in males and $0.37-0.38$ in females. Male: protopodite 1.8 times as long as wide, with 1 lateral seta and 8-9 apical spiniform setae; rami unequal, endopodite short, about 13 times shorter than exopodite, with 1 small simple and 1 spiniform seta an laterally and 2 setae apically, including 1 spiniform and 1 long plumose seta; distal article is 0.87 of length of proximal article, with 5-6 groups of thin-flexible setae along each margin and group of simple setae apically; proximal article with 5 groups of thin-flexible, plumose and spiniform setae along inner and outer margins. Female: protopodite 1.8-2.0 times as long as wide, with $0-1$ lateral seta and 8-9 apical spiniform setae; rami unequal, endopodite short, about 9.7-10 times shorter than exopodite, with 1 small simple seta laterally and 2 setae apically, including 1 spiniform and 1 plumose seta; distal article is 0.3 of length of proximal article, with 2 groups of thin-flexible setae along each margin and group of simple setae apically; proximal article with 4-5 groups of spiniform and thin-flexible setae along outer margin and 6-7 groups of thin-flexible, plumose and spiniform setae along inner margin.

TELSON (Fig. 12D-F): length/width ratio is $1 / 0.74-0.75$; cleft is $0.67-0.71$ of length of telson; margins straight or weakly rounded, narrowing apically; with variable armature, including 3-4 medium distal spines on each lobe and 1 (rarely 2) lateral spine, accompanied by 2 plumose setae on each outer margins, $0-1$ small spine on inner margin; dorsal surface with 1 (rarely 2) small or medium dorsal submarginal spine on each side and 1-2 small mesial setae; apical spiniform setae are $0.36-0.41$ of length of telson.

COLORATION. Body, appendages and internal organs are whitish or yellowish characteristic of stygobiotic representatives of the genus (Fig. 4B).

BODY SIZE. The largest collected $q$ has tbl. $7.0 \mathrm{~mm}$; the largest collected $O^{7}$ has tbl. $8.0 \mathrm{~mm}$.

GENBANK (NCBI) ACCESSION NUMBERS. MZ382387-MZ382405.

TAXONOMIC REMARKS. Niphargus utrishensis sp.n. is morphologically close and phylogenetically related to $N$. alisae sp.n. and $N$. novorossicus sp.n. (Fig. 1), but it can be separated from the related species of the "tauricus" ingroup (see Table 1) by 1) a relatively short antenna I with 23 articles (vs. 26-28 articles in other species); and 2) a relatively longer propo- 
dus of pereopod VI with length/width ratio is about 0.97 (vs. about $0.76-0.93$ in other species).

ETYMOLOGY. The species is named after the Utrish State Nature Reserve, located on the western part of the Navagirsky Ridge, representing the first locality, where the new species was found.

ECOLOGY AND DISTRIBUTION. Niphargus utrishensis sp.n. inhabits various water sources (springs, spring pools, wells, streams and river hyporhea) in the western part of the Navagirsky Ridge of the Abrau Peninsula (Krasnodar Krai), as well as the foothills of the Marktokh and Kotsekhursky ridges in the vicinity of Gostagayevskaya and Varenikovskaya villages, respectively (Figs 2; 3), which are connected geologically, being parts of the Abrau fault zone (Trikhunkov et al., 2018); was also found in a small springs in the basins and hyporhea of small mountain rivers (Gostagayka, Psebeps, Kudako, Bakanka, Lipki and Bogogo), flowing from the NW part of the foothills of the Great Caucasian Ridge. Meanwhile, this species was not found in the springs of the nearby Semisamsky Ridge. Individuals of this species were found under boulders in rivers, and inside springs under fallen flooded leaves or nearby moss.

Niphargus novorossicus Marin et Palatov sp.n. Figs 13-16; 33C.

MATERIAL EXAMINED. HOLOTYPE, $\mathrm{O}^{7}$ (bl. $8.2 \mathrm{~mm}$ ) (ZMMU Mb-1187), RUSSIA, Krasnodar Krai, SW part of the Navagirsky Ridge, Novorossiysk Urban area, the city of Novorossiysk, Koldun Mount., NW of Myskhako, $44^{\circ} 40.062^{\prime} \mathrm{N}, 37^{\circ} 44.492^{\prime} \mathrm{E}$, about 75 ma.s.1., inside a small spring, hand net sampling, coll. I. Marin \& D. Palatov, 6.05.2018. PARATYPES, 1 웅 (bl. $5.6 \mathrm{~mm})\left(\mathrm{ZMMU}\right.$ Mb-1188); $2 \sigma^{\top} \sigma^{\top}, 1+$ 우 (bl. 5.5-7.0 mm) (ZMMU Mb-1189), 10', 10 우 (bl. 4.0-7.0 mm), ZMMU Mb-1189, same data and locality as holotype.

ADDITIONAL MATERIAL. RUSSIA, Krasnodar Krai, Novorossiysk Urban area, SW part of the Navagirsky Ridge, the city of No- vorossiysk: $10^{\top}, 1$ ( 9 (LEMMI), SW slope of Sapun Mount., Shirokaya Balka, $44^{\circ} 42.136^{\prime} \mathrm{N}$, $37^{\circ} 42.279^{\prime} \mathrm{E}$, about $156 \mathrm{~m}$ a.s.1., a small spring in the riverbed of the Shirokaya Balka River, hand net sampling, coll. I. Marin \& D. Palatov, 6.05.2018; $2 \sigma^{7} \sigma^{7}, 3+\circ$ (LEMMI), N slope of Sapun Mount., 12 Waterfalls area, $44^{\circ} 43.368^{\prime} \mathrm{N}$, $37^{\circ} 43.827^{\prime} \mathrm{E}$, about $87 \mathrm{~m}$ a.s.1., inside a small spring, hand net sampling, coll. I. Marin \& S. Marina, 18.08.2019; 5우 (LEMMI), Sapun Mount., $44^{\circ} 42.638^{\prime} \mathrm{N}, 37^{\circ} 41.422^{\prime} \mathrm{E}$, about 326 $\mathrm{m}$ a.s.1., inside a small spring, hand net sampling, coll. Marin \& D. Palatov, 6.05.2018; $10^{7}$, 10우 (bl. 4.0-7.0 mm), Koldun Mount., NW of Myskhako, $44^{\circ} 40.062^{\prime} \mathrm{N}, 37^{\circ} 44.492^{\prime} \mathrm{E}$, about $75 \mathrm{~m}$ a.s.1., inside a small spring, hand net sampling, coll. I. Marin \& D. Palatov, 6.05.2018.

DESCRIPTION.

BODY: depigmented, moderately slender.

HEAD: length is approximately $10-11 \%$ of body length; rostrum and pigmented spots on anterior lobe absent, with subrounded lateral cephalic lobes and excavated anteroventral sinus.

PEREON: pereonites I-VII without setae, smooth.

PLEOSOMA: pleonites I-III with several short marginal setae on each posterodorsal margin.

EPIMERAL PLATES: posteroventral corners of epimeral plates I-III nearly right-angled, slightly rounded (Fig. 16A-C). Epimeral plate I: posterior and ventral margin slightly convex; without spines along ventral margin; with 5 setae along posterior margin; posteroventral angle with 1 strong seta. Epimeral plate II: posterior margin slightly concaved, ventral margin convex; with 2 spiniform setae along ventral margin; 5 setae along posterior margin; posteroventral angle with 1 strong seta. Epimeral plate III: posterior margin concave, ventral margin slightly convex; with 3 spiniform setae along ventral margin; with 7 setae along posterior margin; posteroventral angle with 1 strong seta.

UROSOMITES (Fig. 33C): urosomite I with 1 spine on each side dorsolaterally, with 1 posteroventral spines near basis of uropod I 

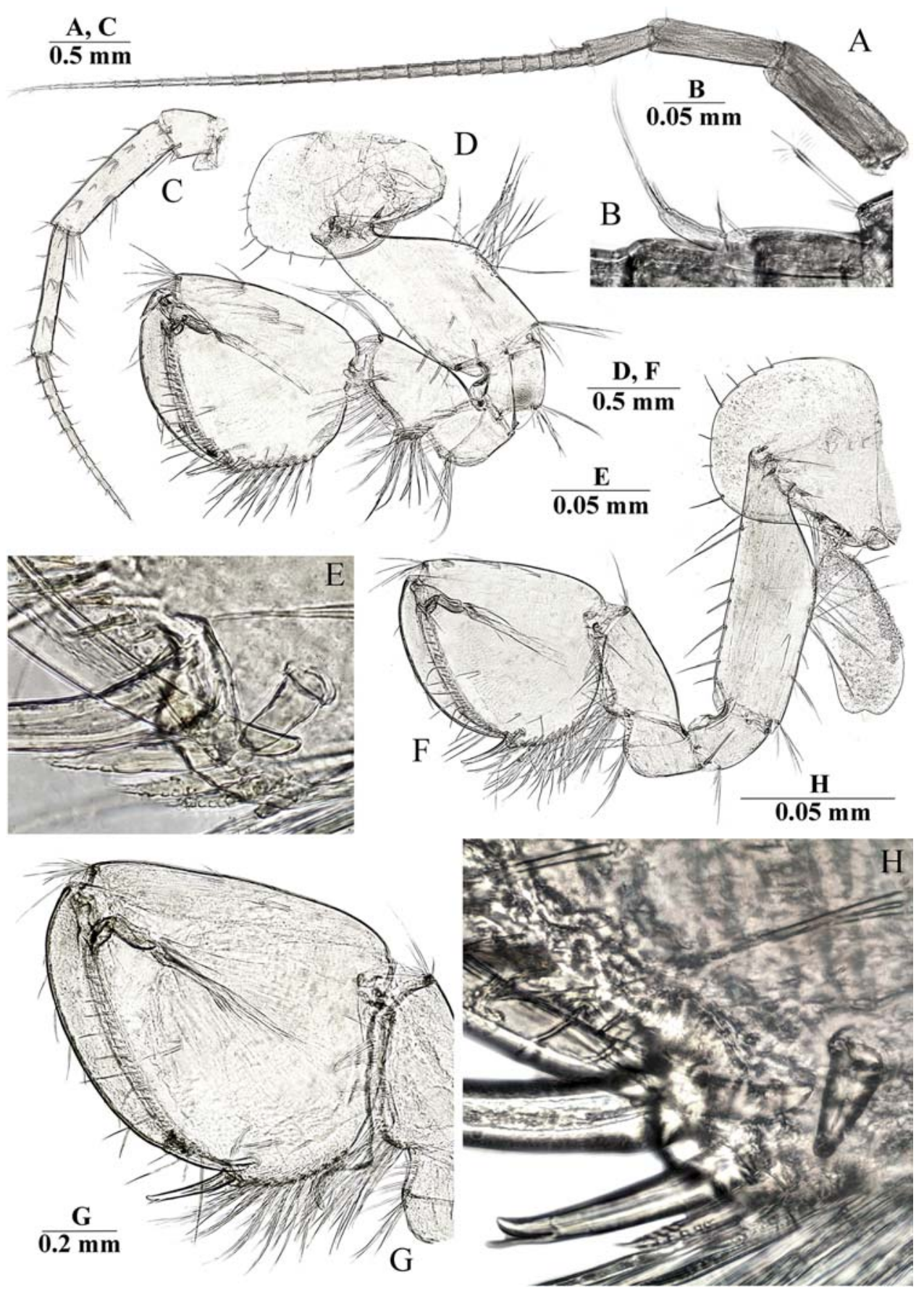

Fig. 13. Niphargus novorossicus sp.n., $\mathrm{O}^{\top}$ : A - antenna I; B - accessory flagellum of antenna I; C antenna II; D - gnathopod I; E - distoventral corner of chela of GnI; F - gnathopod II; G - palmar margin of chela of GnII; H - same, distoventral corner.

Pис. 13. Niphargus novorossicus sp.n., О7: А — антенна I; В — дополнительный жгутик антенны I; C антенна II; D - гнатопод I; E — дистовентральный угол клешни GnI; F — гнатопод II; G дистовентральный угол клешни GnII. 
Euxinian relict amphipods in the subterranean fauna of the Northern Black Sea region 277

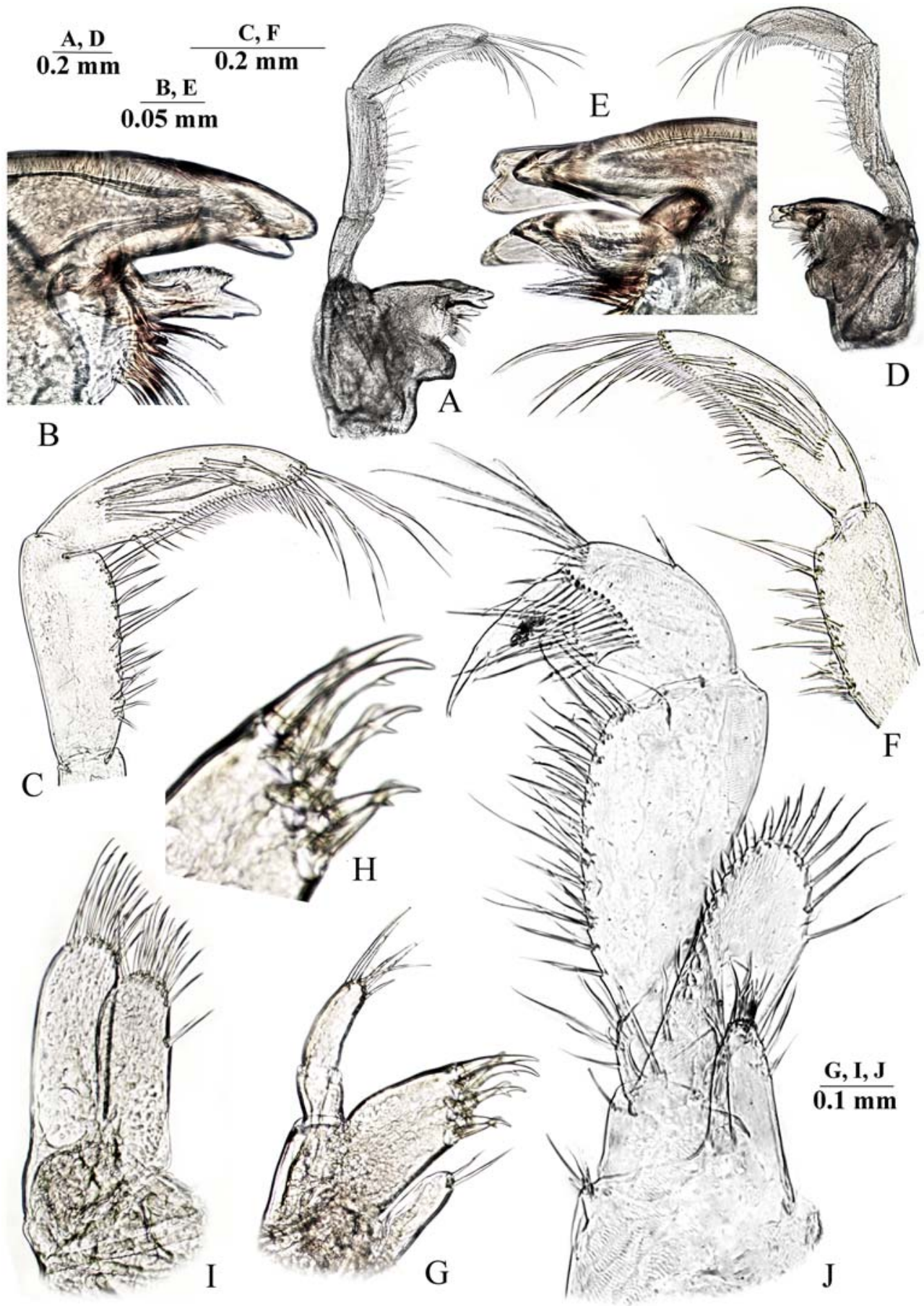

Fig. 14. Niphargus novorossicus sp.n., O': A, C, D, F - mandible; B, E - incisor process and pars incisiva of mandible; $\mathrm{G}$ - maxilla I; H - same, distal margin of outer lobe; I - maxilla II; J - maxilliped. Pис. 14. Niphargus novorossicus sp.n., О७: А, C, D, F — мандибула; В, E - режущий отросток и pars incisiva (резец) мандибулы; G - максилла I; H — то же, дистальный край наружной доли; I максилла II; J - максиллипед. 


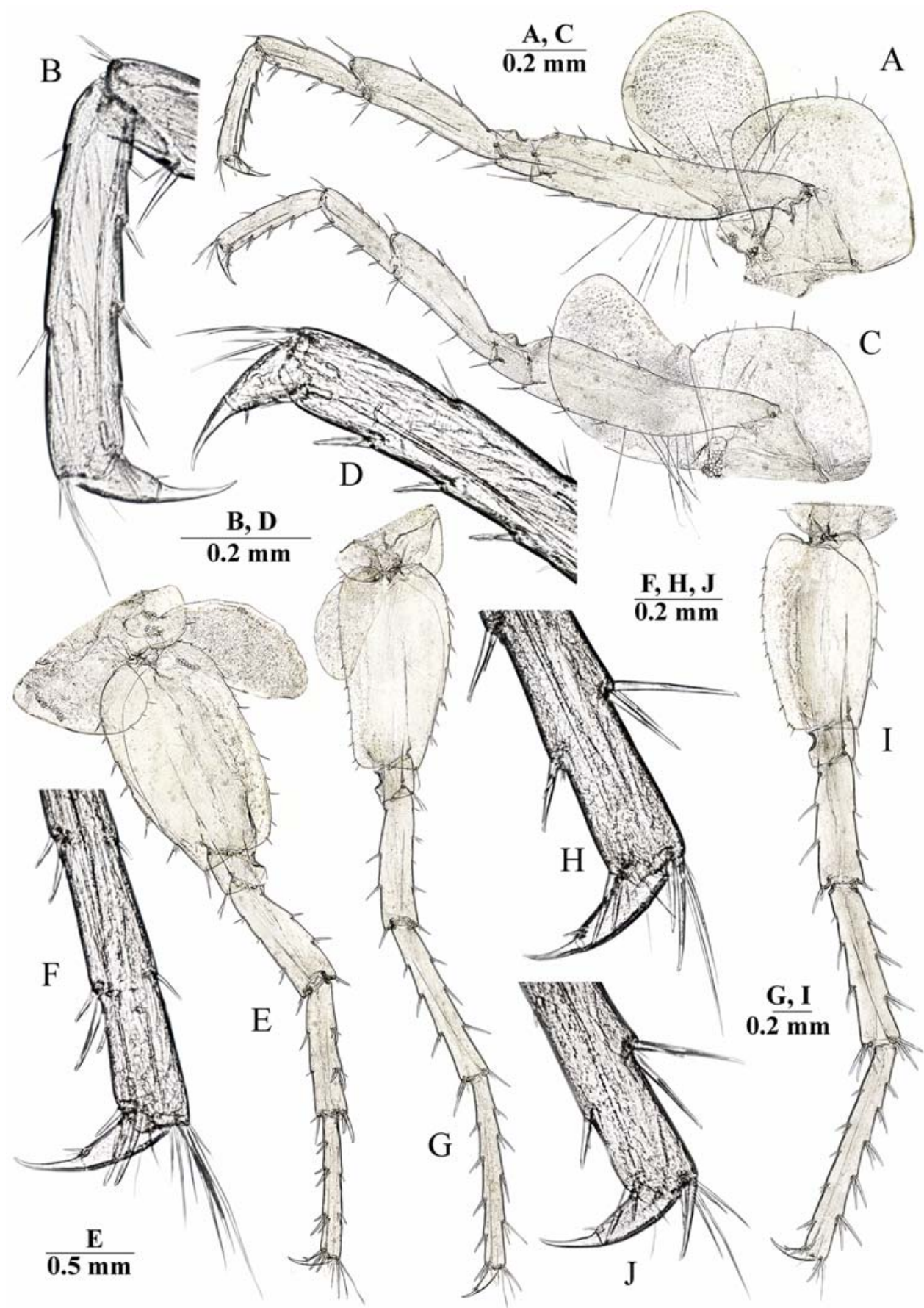

Fig. 15. Niphargus novorossicus sp.n., O': A — pereopod III; B — dactylus of PIII; C - pereopod IV; D dactylus of PIV; E - pereopod V; F - dactylus of PV; G - pereopod VI; H - dactylus of PVI; I pereopod VII; J - dactylus of PVII.

Fig. 15. Niphargus novorossicus sp.n., Оج: А — переопод III. В - дактилус PIII; C - переопод IV; D дактилус PIV; E — переопод V; F — дактилус PV; G — переопод VI; H — дактилус PVI; I — переопод VII; J - дактилус VII. 

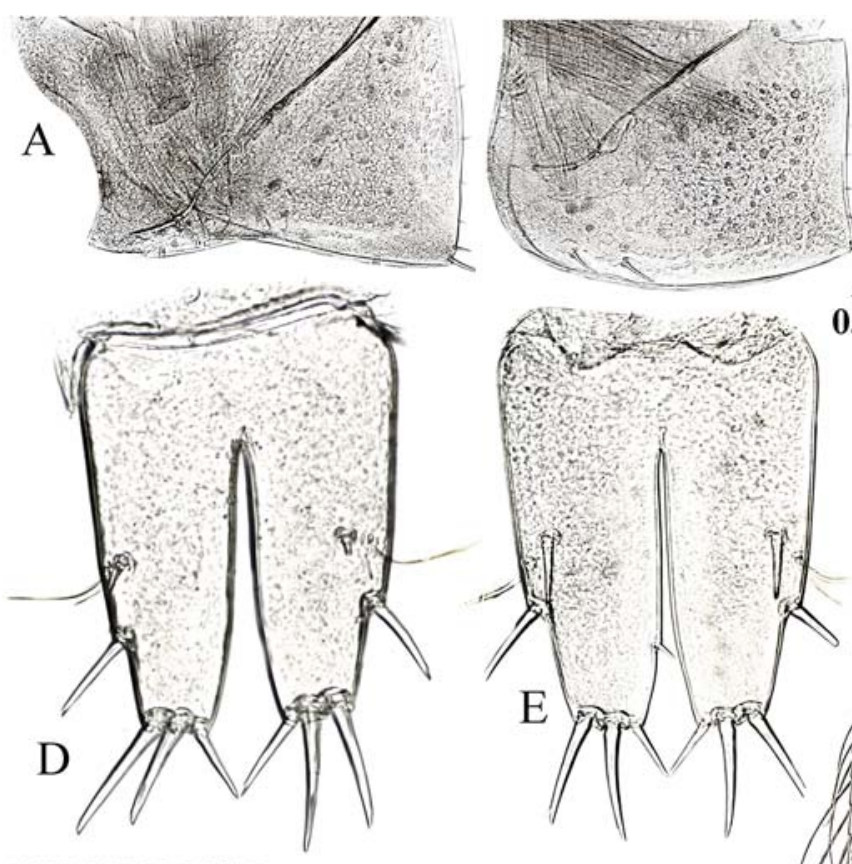

\section{A - C}
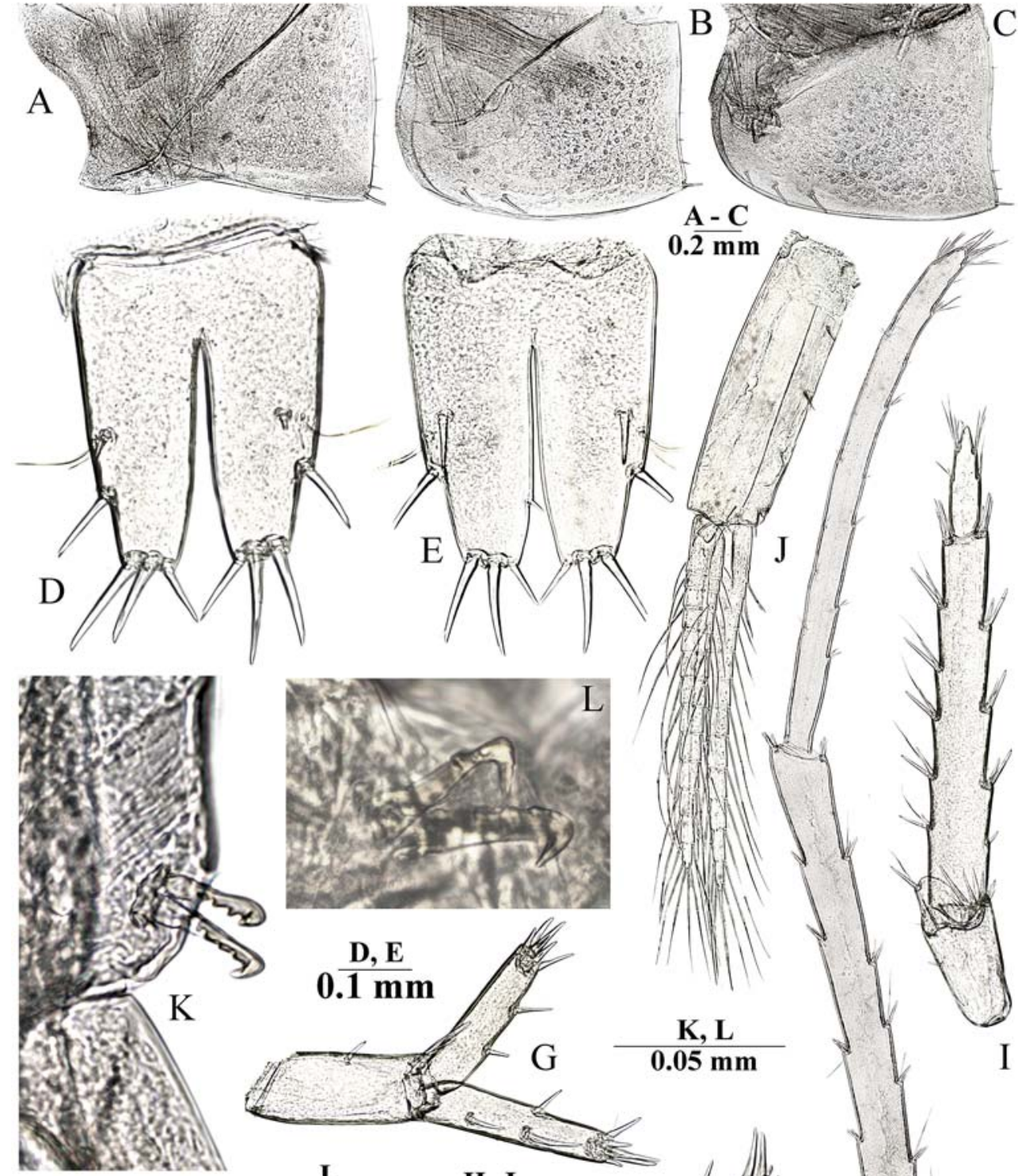

$\mathbf{K}, \mathbf{L}$ $0.05 \mathrm{~mm}$

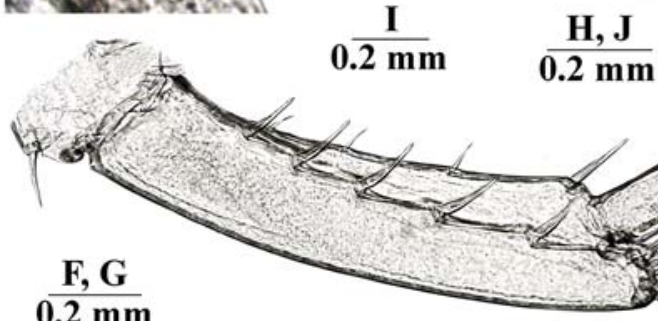
$\mathbf{H , ~ J}$ $0.2 \mathrm{~mm}$

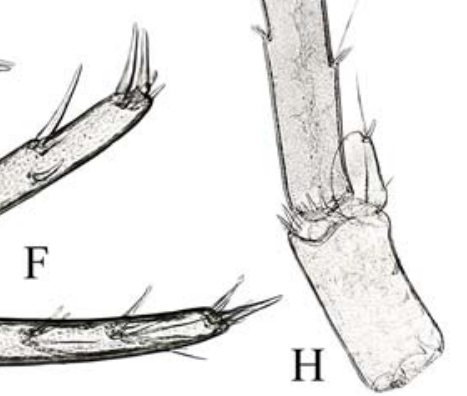

Fig. 16. Niphargus novorossicus sp.n., $\mathrm{O}^{\top}:(\mathrm{A}-\mathrm{D}, \mathrm{H}, \mathrm{J}-\mathrm{K})$ and $q$ (E, I): A-C - epimeral plates I-III; D-E telson; F - uropod I; G - uropod II; H, I — uropod III; J - pleopod III; K-L - retinacula of pleopod III. Рис. 16. Niphargus novorossicus sp.n., О : (А-D, Н, J-K) и + (Е, I): А-C - эпимеральные пластинки I-III; D-E - тельсон; F — уропод I; G - уропод II; H, I - уропод III; J — плеопод III; $\mathrm{K}-\mathrm{L}$ ретинакула плеопод III. 
dorsolaterally; urosomite II with 2 simple strong spine accompanying 1 simple seta on each side dorsolaterally; urosomite III unarmed.

COXAE (Figs 13D, H; 16A, C, E, G, I): coxal plate I oval, with rounded anteroventral corner, armed with 7 setae; width/depth ratio is $0.77 / 1$; width/depth ratio of coxal plates II-IV are $1 / 0.9,1 / 1.05$ and $1 / 0.94$, respectively; anterior and ventral margins of coxal plates II and IV with 7 setae each, anterior and ventral margins of coxal plates III with 12 setae; with rounded anteroventral corners; coxal plates V-VI with large lobes anteriorly, posterior margins with 1 and 2 setae, respectively; anterior margins with 4 and 0 setae respectively; coxal plate VII trapezoid, with concave ventral margin; posterior lobe with 1 seta; coxal gills II-VI ovoid, gills/bases ratio of pereopods are $0.67 / 1,0.77 /$ $1,0.9 / 1,0.74 / 1$ and $0.58 / 1$, respectively.

ANTENNA I (Fig. 13A): slender, about $0.56-0.58$ of body length; peduncular articles moderately slender, with ratio is $1 / 0.82 / 0.45$; flagellum consisting of 26 articles, most of them with 2 short aesthetascs each; accessory flagellum short, 2-articulated (Fig. 13B); antennas I/ II ratio is $1 / 0.71$.

ANTENNA II (Fig. 13C): peduncular articles moderately stout, with several long setae along ventral margin, dorsal setae shorter than inner ones; flagellum relatively short, consisting of 12 articles with relatively short setae; length of peduncle articles $4 / 5$ is $1 / 0.9$; flagellum is 0.67 times of length of peduncular articles $4+5$.

LABRUM: typical.

LABIUM: with entire, subrounded outer lobes and well developed smaller inner lobes.

MANDIBLES (Fig. 14A, D). Left mandible: incisor process with 5 teeth, lacinia mobilis with 4 teeth; with row of 8 serrated setae between lacinia and molar process, few spatulate setae and 1 long seta at base of molar (Fig. 14B); mandibular palp article $2 / 3$ (distal) ratio is $1 / 1-$ 1.14; proximal article of palp without setae; article 2 with 18 setae; distal article with group of 6 A-setae; 3 groups of B-setae; 30-32 Dsetae and 5 E-setae (Fig. 14C, F). Right mandible: incisor process with 4 teeth, lacinia mobilis bifurcate, with row of 8 serrated setae between lacinia and molar process (Fig. 14E).

MAXILLA I (Fig. 14G): inner lobe with 2 distal setae, outer lobe with 7 robust spines (6 spines with 1 strong lateral tooth each, inner spine with 4 small lateral teeth (1-1-1-1-1-14) (Fig. 14H); palp 2-articulated, distal article with 6 simple setae distally.

MAXILLA II (Fig. 14I): both plates with numerous long distal simple setae, outer lobe with row of fine setae along outer margin.

MAXILLIPED (Fig. 14J): inner plate short, with 2 distal robust setae intermixed with 7 distal simple setae; outer plate reaching half of palpal article 2 and bearing row of 22-23 distolateral spines and distal setae; palpal article 3 with 1 median and 1 distal bunches of seta at outer margin; palpal article 4 with 1 median seta at outer margin; nail shorter than pedestal, with 2 setae near basis.

GNATHOPOD I (Fig. 13D): basis elongated, with distal part greatly expanded; ischium with group of 5-6 posterodistal setae; merus subquadrate, equal to ischium; carpus is 0.48 of length of basis and 0.52 of length of propodus, with single distal group of setae anteriorly, with transverse rows of setae along posterior margin and row of setae posterolaterally; propodus subtrapezoidal, setose, with 7 rows of setae at posterior margin, anterior surface with 3 groups of total 4-6 setae each in addition to anterodistal group of 6-7 setae, several groups of short setae on inner surface, palmar corner armed with 1 long spiniform palmar seta, 4 serrated spiniform setae, single supporting spiniform seta on inner surface (Fig. 13E); dactylus with 6 setae along anterior margin, with row of short setae along inner surface; the length of nail is 0.30 of total length of dactylus.

GNATHOPOD II (Fig. 13F-G): width/ length ratio of basis is $0.30-0.33 / 1$, with 6 dorsolateral setae; ischium with 5 posterodistal setae; merus subquadrate, equal to ischium; carpus is 0.43 of length of basis and 0.56 of length of propodus, with distal group of setae anteriorly, few transverse rows of setae along posterior margin and row of setae posterolaterally; propodus subtrapezoidal, setose, larger 
than propodus of $\mathrm{GnI}(\mathrm{GnI} / \mathrm{II}$ as $0.9 / 1)$, posterior margin with 10 rows of setae, anterior surface with 2 group setae in addition to 6-7 anterodistal setae, with several groups of setae on inner surface, palmar corner with 1 strong palmar spiniform seta, 1 supporting spiniform seta on inner surface and 2 denticulated thick spiniform setae on outer side (Fig. 13H); dactylus with 4 setae along anterior surface and few short setae along inner surface; length of nail is about 0.29 0.30 of total length of dactylus.

PEREOPODS III-IV (Fig. 15A, C): almost similar in size and shape; basis is $4.55-4.62$ times as long as wide, with posterior margin bearing long marginal setae, with distoventral group of setae; ischium short, subquadrate, with distoventral group of setae; merus with slender simple setae along anterior and posterior surfaces; carpus/propodus ratio is $0.90-0.97$; propodus with 4 groups of spines along ventral margin; dactylus (Fig. 15B, D) relatively stout, curved, sharp distally, with 1 small additional posterior median spine and 1 median short plumose seta at outer margin; dactyli ratio of PpIII/ IV is $1 / 1.14$; length of nail is $0.46-0.48$ of total length of dactylus.

PEREOPODS V-VII(Fig. 15E, G, I): length ratio of $\mathrm{PpV} / \mathrm{VI} / \mathrm{VII}$ is $1 / 1.55 / 1.53$; length of PVII is about half of total body length.

PEREOPOD V (Fig. 15E): length/width ratio of basis is $1 / 0.61$, almost rectangular, with explicit posteroventral lobe; with facial setae; posterior margin slightly convex, with row of 13 slender marginal setae; anterior margin convex, with row of 6 slender marginal setae, which are distinctly longer than posterior ones, and group of setae in distal part; ischium subquadrate; merus with 3 bunches of slender spines along anterior surface and with 2 spines on posterior surface; propodus slender, 7.4 times as long as wide, with several bunches of short spines; dactylus (Fig. 15F) with 1 small additional posterior median spine and 1 median short plumose seta at outer margin.

PEREOPOD VI (Fig. 15G): length/width ratio of basis is $1 / 0.54$, with facial setae, posteroventral lobe and slightly concave posterior margin bearing row of 15 short marginal setae, anterior margin convex, with row of 8 longer marginal setae; merus with several bunches of short spines along anterior and posterior surfaces; carpus with group of spines intermixed with single short setae; propodus slender, about 9.1 times as long as wide, with several group of short spines; dactylus (Fig. 15H) slender, with 1 small additional posterior median spine and 1 short median plumose seta at outer margin.

PEREOPOD VII (Fig. 15I): male: length/ width ratio of basis is $1 / 0.59$, with posteroventral lobe and slightly convex posterior margin bearing arow of 13 short marginal setae; with facial setae; anterior margin convex, with row of 4 longer marginal setae; carpus with 3 groups of short spines along anterior and posterior surfaces; propodus slender, about 8 times as long as wide, with several groups of short spines; dactylus (Fig. 15J) with 1 median spine and 1 seta at inner margin, and 1 short median plumose seta at outer margin. Female: length/width ratio of basis is $1 / 0.63$, with distinct posteroventral lobe and distinctly convex posterior margin bearing row of 10 short marginal setae; with facial setae; anterior margin convex, with row of 6 longer marginal setae; ishium about as long as wide; merus with several bunches of short spines along anterior and posterior margins; carpus with 3 groups of short spines along anterior and 2 groups along posterior margins; propodus slender, about 6.6 times as long as wide, with several groups of short spines; dactylus with 1 median spine and 1 seta at inner margin, and 1 short median plumose seta at outer margin.

PLEOPODS (Fig. 16J): pleopod I with basal segment armed with 1-2 small simple setae and 2 coupling hooks in retinacula; pleopod II with basal segments armed with 1 small simple seta and 2 coupling hooks in retinacula; pleopod III with basal segment armed with 3 small and medium-sized simple setae and 2 coupling hooks accompanied by 1 large simple seta in retinacula (Fig. 16K-L).

UROPOD I (Fig. 16F): protopodite longer than rami, 4.4 times as long as wide, with dorsointernal row of 3 median setae and one subdistal spine and dorsoexternal row of 5 spines; rami straight and subequal in length both in males 
andin males and females, endopodite not paddle-like, with 3 dorsolateral and 2 mesial spines without setae, 4 apical spines; exopodite with 2 mesial groups consisting of single spines accompanying by several (2-4) simple setae and 1 mesial group consisting of 2 spines, with 4 apical spines.

UROPOD II (Fig. 16G): protopodite 2.5 times as long as wide, subequal rami; rami with lateral, mesial and distal slender spines, endopodite with 2 spines ventrolaterally, 5 spines apically; exopodite with 1 spine dorsolaterally and 2 spines mesially, 5 spines apically; exopodite/endopodite ratio is $1 / 1.18$.

UROPOD III(Fig. 16H-I): different in males and females, about $0.58-0.6$ of body length in males and $0.36-0.38$ in females. Male: protopodite 1.95-2.0 times as long as wide, with 2 lateral seta and 9-10 apical spiniform setae; rami unequal, endopodite short, about 16 times shorter than exopodite, with 1 small simple seta an laterally and 2 setae subapically, including 1 spiniform and 1 long plumose seta; distal and proximal articles subequal in length; distal article with 6-7 groups of thin-flexible setae along each margin and group of simple setae apically; proximal article with 4 groups of spiniform setae along outer margin and 5 groups of thinflexible, plumose and spiniform setae along inner margin. Female: protopodite 1.78 times as long as wide, with 1 lateral seta and 8-9 apical spiniform setae; rami unequal, endopodite short, about 8.2 times shorter than exopodite, with 1 small simple seta laterally, 2 setae subapically, including 1 spiniform and 1 long plumose seta; distal article is 0.30 of length of proximal article, with 2 groups of thin-flexible setae along each margin and group of simple setae apically; proximal article with 4 groups of spiniform setae along outer margin and 5 groups of thinflexible, plumose and spiniform setae along inner margin.

TELSON (Fig. 16D-E): length/width ratio is $1 / 0.77-0.81$; cleft is $0.69-0.72$ of length of telson; margins straight, narrowing apically; with variable armature, including 3 medium distal spines on each lobe, 1 lateral spine, accompanying by 2 plumose setae on each outer margins, $0-1$ spine on inner margins on each side, 1 sublateral spine and 1 small mesial seta on dorsal surface; apical spiniform setae are 0.30 of length of telson.

COLORATION. Body, appendages and internal organs are whitish or yellowish characteristic to stygobiotic representatives of the genus.

BODY SIZE. The largest collected $q$ has tbl. $7.0 \mathrm{~mm}$; the largest collected $\sigma^{7}$ has tbl. $8.2 \mathrm{~mm}$.

GENBANK (NCBI) ACCESSION NUMBERS. MZ382320-MZ382322.

TAXONOMIC REMARKS. Niphargus novorossicus sp.n. is mostly morphologically close and phylogenetically related to $N$. utrishensis sp.n. and $N$. alisae sp.n. (Fig. 1), but can be separated from the latter and related species of the "tauricus" ingroup (see Table 1) by 1) a distally pointed posteroventral angle of epimeral plate III; and 2) a relatively long antenna II with 26 articles that clearly separate the species from $N$. tauricus.

ETYMOLOGY. The species is named after the city of Novorossiysk, located around the Sapun and Koldun mountains of the Navagirsky Ridge, most of which is inhabited by the new species.

ECOLOGY AND DISTRIBUTION. Niphargus novorossicus sp.n. inhabits various water sources (springs, spring pools, wells, streams and river hyporhea) in the area of the Sapun and Koldun mountains (Novorossiysk area) of the Abrau Peninsula (Krasnodar Krai) (Figs 2; 3). These mountains are considered part of the Navagirsky Ridge, but are separated by the Raevo-Abrau Depression; also, according to another version, these mountains are part of the Coastal Ridge, part of which as a result of a karst collapse became the Tsemes (=Tsemesskaya, Novorossiyskaya) Bay of the Black Sea (Trikhunkov et al., 2018).

\section{Niphargus alisae Marin, Krylenko et Palatov sp.n.}

Figs 17-20; 33E.

MATERIAL EXAMINED. HOLOTYPE, O' (bl. $9.5 \mathrm{~mm}$ ), ZMMU Mb-1192, RUSSIA, Krasnodar Krai, Gelendzhik Urban area, Doob 
Peninsula, S slope of the Tuapkhat Ridge, 1.2 $\mathrm{km}$ NW of the Blue Bay and the city of Gelendzhik, Shel 1, 443 $34.902^{\prime} \mathrm{N}, 37^{\circ} 57.971^{\prime} \mathrm{E}$, about $38 \mathrm{~m}$ a.s.l., a small spring flowing into the Black Sea, hand net sampling, coll. I. Marin \& D. Palatov, 20.04.2018. PARATYPES, $2 \sigma^{\top} \sigma^{\top}$, 8우 (bl. 6.0-7.0 mm) (ZMMU Mb-1193), same locality and data as holotype.

ADDITIONAL MATERIAL. RUSSIA, Southwestern Caucasus, Krasnodar Krai, Gelendzhik Urban area, Doob Peninsula, S slope of the Tuapkhat Ridge: $3 \sigma^{7} \sigma^{7}, 3$ 우 (LEMMI), Kontorskaya Shel, $44^{\circ} 35.034^{\prime} \mathrm{N}, 37^{\circ} 58.541^{\prime} \mathrm{E}$, about $83 \mathrm{~m}$ a.s.l., a small spring flowing into the Black sea, hand net sampling, coll. S. Krylenko, 5.01.2018; 5 우 (LEMMI), Shel 3, 443․ $35.248^{\prime} \mathrm{N}$, $37^{\circ} 57.605^{\prime} \mathrm{E}$, about $53 \mathrm{~m}$ a.s.1., a small spring, hand net sampling, coll. V. Krylenko, 29.01. 2018; $10^{7}$ (LEMMI), Shel 5, 443․ $355^{\prime} \mathrm{N}$, $37^{\circ} 57.163^{\prime} \mathrm{E}$, about $60 \mathrm{~m}$ a.s.1., a small spring flowing into the Black Sea, hand net sampling, coll. V. Krylenko, 29.01.2018; $10^{7}, 1$ ( (LEM-

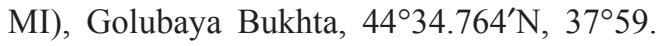
$528^{\prime} \mathrm{E}$, about $48 \mathrm{~m}$ a.s.1., a small spring in the riverbed of the Ashamba River, hand net sampling, coll. V. Krylenko, 4.02.2018; 1 ( (LEMMI), Christova Shel, $44^{\circ} 37.140^{\prime} \mathrm{N}, 37^{\circ} 55.246^{\prime} \mathrm{E}$, about $20 \mathrm{~m}$ a.s.l., a small spring flowing into the Black sea, hand net sampling, coll. V. Krylenko, 21.02.2021; $40^{\top} 0^{\top}$ (LEMMI), Shel 2, 4435. $223^{\prime} \mathrm{N} 37^{\circ} 57.926^{\prime} \mathrm{E}$, about $80 \mathrm{~m}$ a.s.l., inside a small spring, hand net sampling, coll. V. Krylenko, 23.02.2021; $10^{7}$ (LEMMI), Tributary of the Doob River, $44^{\circ} 38.352^{\prime} \mathrm{N}, 37^{\circ} 57.635^{\prime} \mathrm{E}$, about $80 \mathrm{~m}$ a.s.1., inside a small spring, hand net sampling, coll. V. Krylenko, 27.02.2021.

\section{DESCRIPTION.}

BODY: depigmented, moderately slender.

HEAD: length is approximately $10 \%$ of body length; rostrum and pigmented spots on anterior lobe absent, with subrounded lateral cephalic lobes and excavated anteroventral sinus.

PEREON: pereonites I-VII without setae, smooth.

PLEOSOMA: pleonites I-III with several short marginal setae on each posterodorsal margin.

EPIMERAL PLATES: Posteroventral corners of epimeral plates I-II nearly right-angled, slightly rounded; posteroventral corners of epimeral plates III bluntly shaped (Fig. 20A-C). Epimeral plate I: posterior and ventral margin slightly convex; without spines along ventral margin; with 3 setae along posterior margin; posteroventral angle with 1 strong seta. Epimeral plate II: posterior margin slightly concaved, ventral margin convex; with 2 spiniform setae along ventral margin; 5 setae along posterior margin; posteroventral angle with 1 strong seta. Epimeral plate III: posterior margin distinctly concave, ventral margin slightly convex; with 2 spiniform setae along ventral margin; with 7 setae along posterior margin; posteroventral angle with 1 strong seta.

UROSOMITES (Fig. 33E): urosomite I with 1 spine accompanying 1 simple seta on each side dorsolaterally, with 1 posteroventral spine near basis of uropod I dorsolaterally; urosomite II with 3 simple strong spines on each side dorsolaterally; urosomite III unarmed.

COXAE (Figs 17D, F; 19A, C, E, G, I): coxal plate I oval, with rounded anteroventral corner, armed with 7 setae; width/depth ratio is $0.74 / 1$; width/depth ratio of coxal plates II-IV are $1 / 1,1 / 1$ and $1 / 1.03$, respectively; anterior and ventral margins of coxal plates II-III with 10 setae each, anterior and ventral margins of coxal plates IV with 9 setae; with rounded anteroventral corners; coxal plates V-VI with large lobes anteriorly, posterior margins with 2 setae each; anterior margins with 4 and 0 setae respectively; coxal plate VII trapezoid, with concave ventral margin; posterior lobe with 1 seta; coxal gills II-VI ovoid, length gills/bases ratio of pereopods are $0.59-0.60 / 1,0.74 / 1,0.84 /$ $1,0.76 / 1$ and $0.52 / 1$, respectively.

ANTENNA I (Fig. 17A): slender, about $0.53-0.54$ of body length; peduncular articles moderately slender, ratio is $1 / 0.82 / 0.42$; flagellum with 22 articles, most of them with 2 short aesthetascs each; accessory flagellum short, 2articulated (Fig. 19C); antennas I/II ratio is 1/ 0.56 .

ANTENNA II (Fig. 19B): peduncular articles moderately stout, with several long setae along ventral margin, dorsal setae shorter than inner ones; flagellum relatively short, consist- 


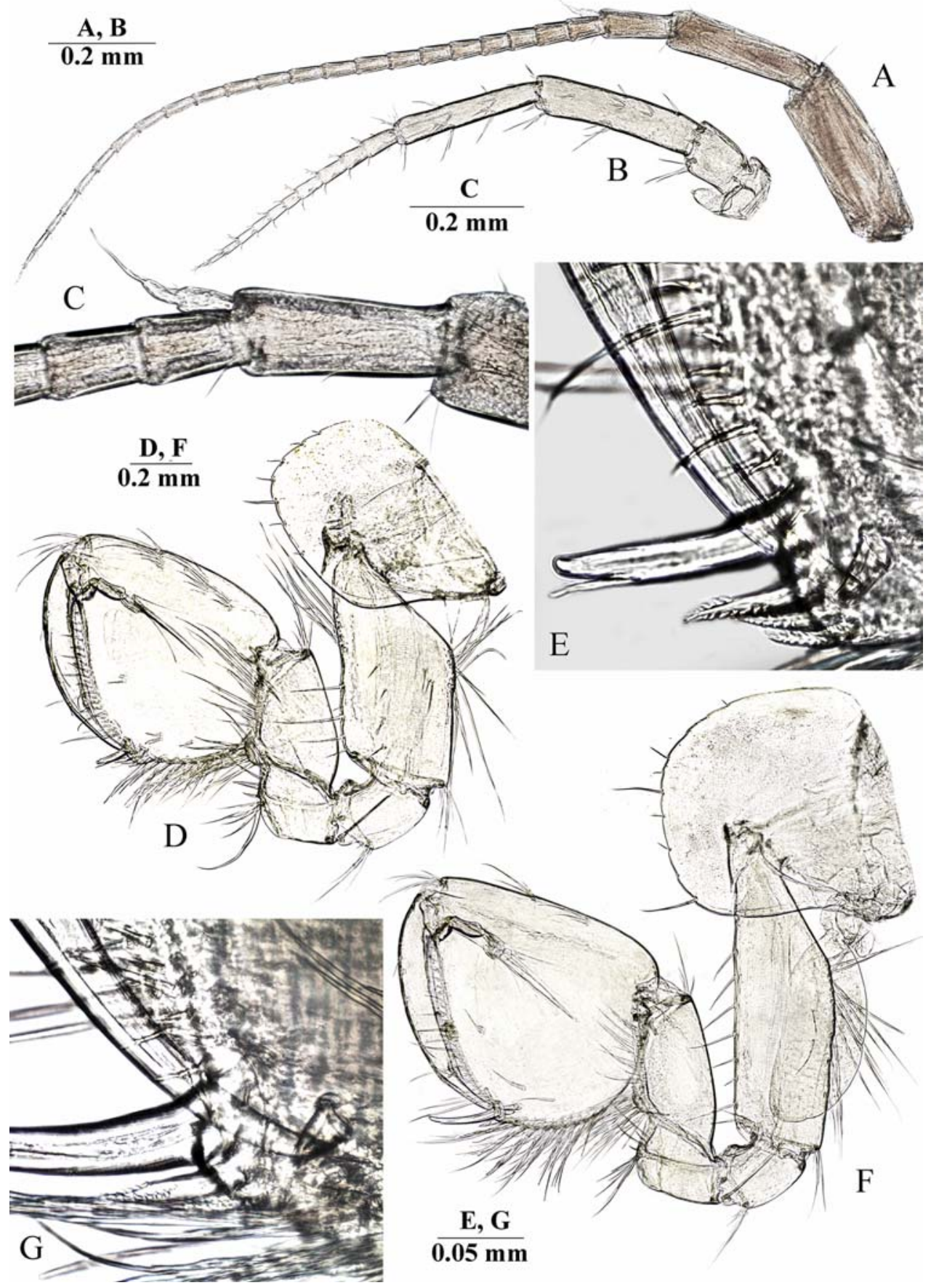

Fig. 17. Niphargus alisae sp.n., O': A — antenna I; C - accessory flagellum of antenna I; B - antenna II; D - gnathopod I; E - distoventral corner of chela of GnI; F - gnathopod II; G - distoventral corner of chela of GnII.

Рис. 17. Niphargus alisae sp.n., О7: А - антенна I; В - дополнительный жгутик антенны I; C антенна II; D - гнатопод I; E — дистовентральный угол клешни GnI; F — гнатопод II; G дистовентральный угол клешни GnII. 
Euxinian relict amphipods in the subterranean fauna of the Northern Black Sea region 285
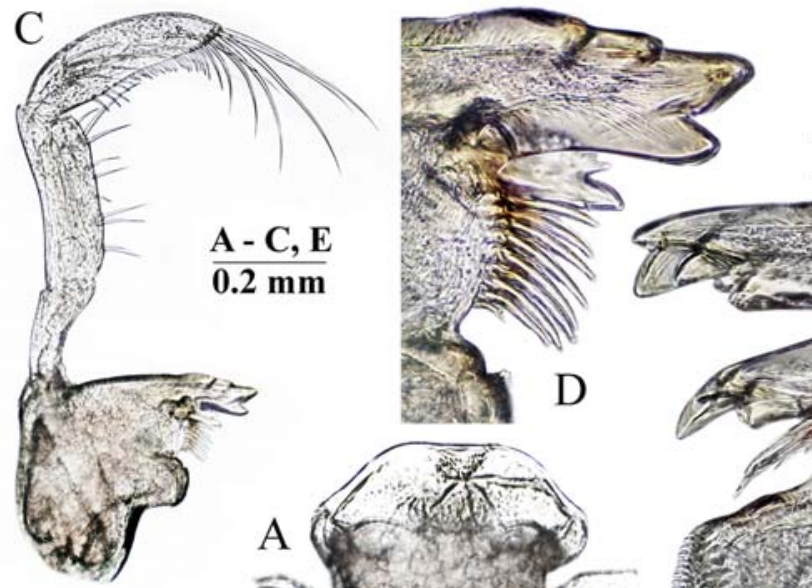

$\mathrm{F}$
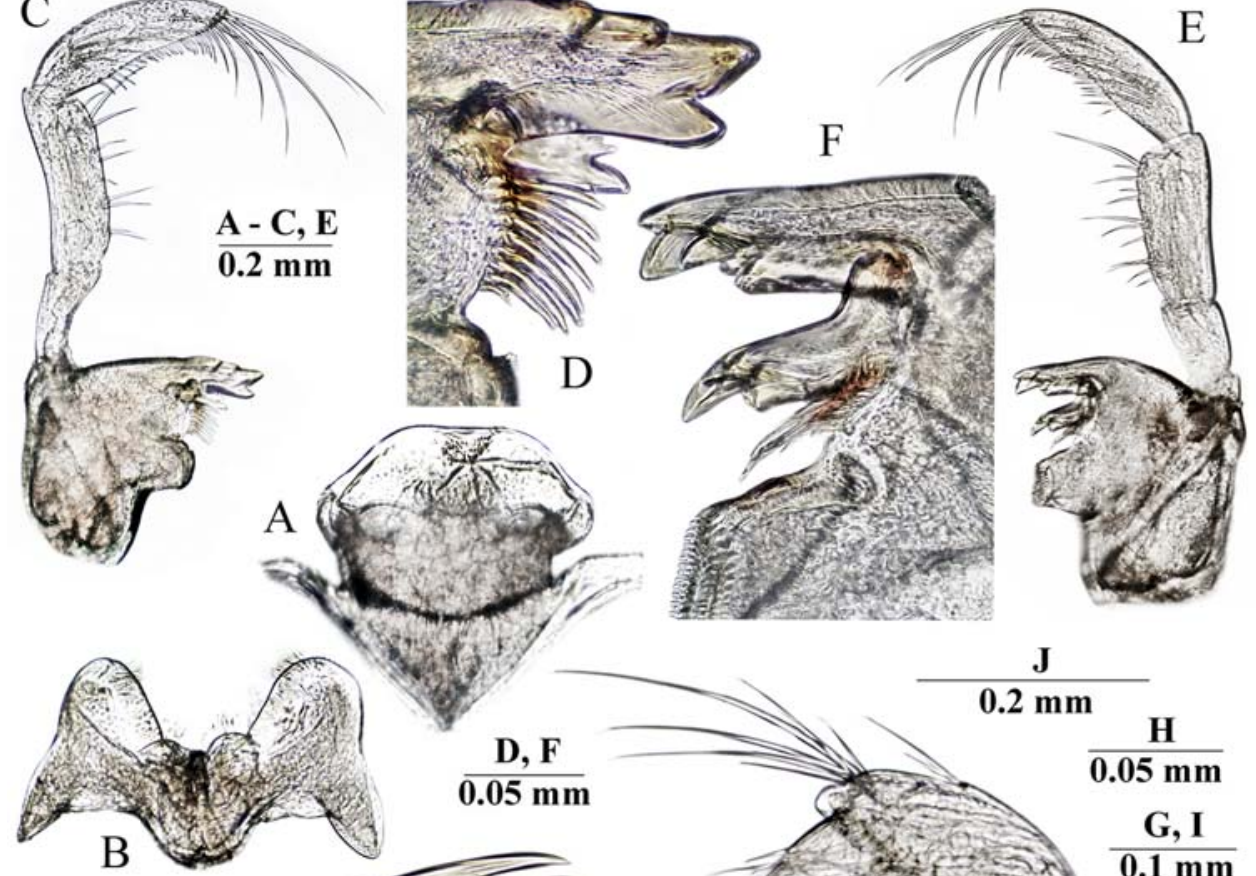

$\mathbf{J}$
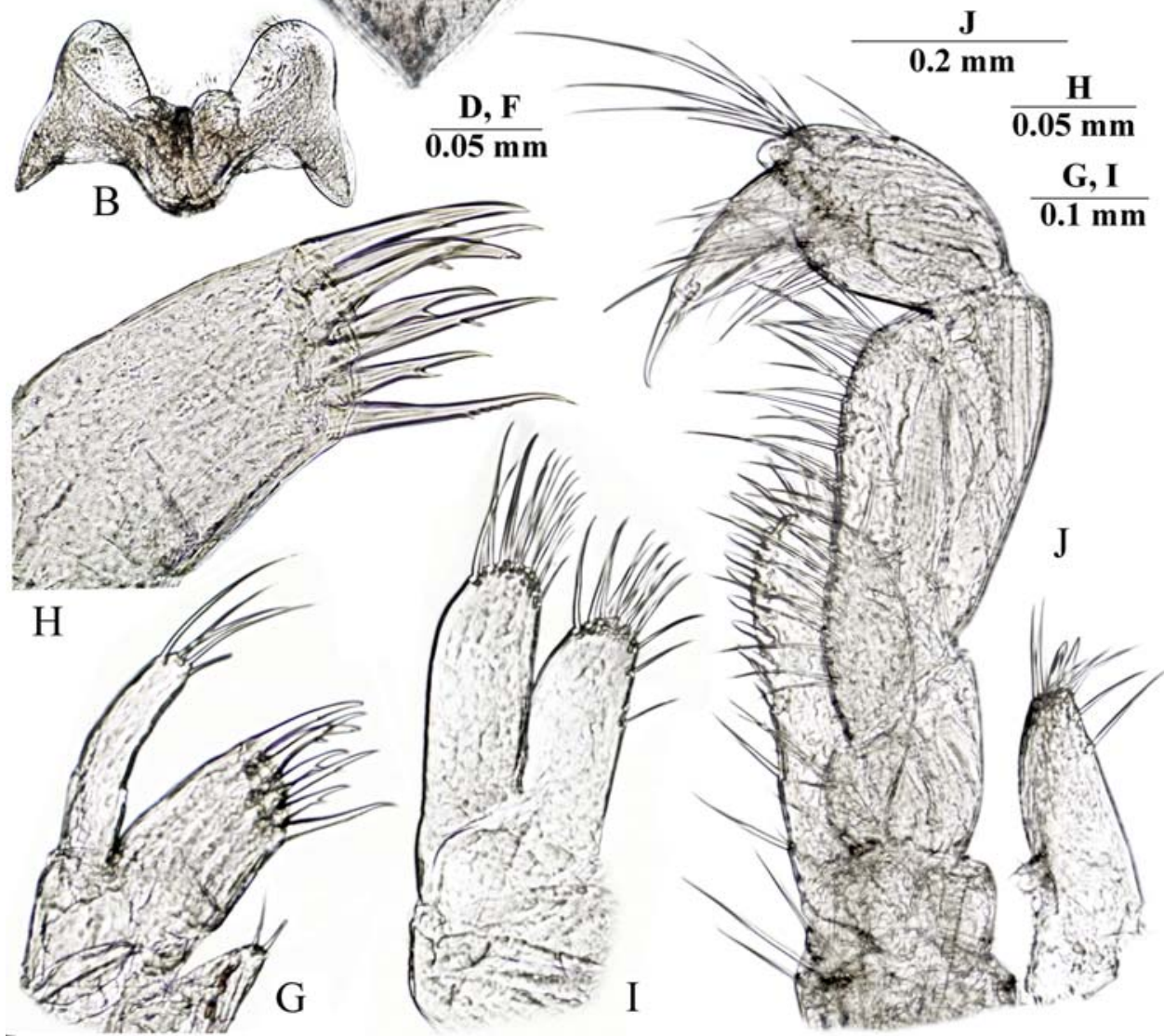

Fig. 18. Niphargus alisae sp.n., O: A - labrum; B - labium; C, E - mandible; D, F - incisor process and pars incisiva of mandible; $\mathrm{G}$ - maxilla I; H — same, distal margin of outer lobe; I — maxilla II; J maxilliped.

Рис. 18. Niphargus alisae sp.n., о : А — верхняя губа; В - нижняя губа; C, Е - мандибула; D, F режущий отросток и pars incisiva (резец) мандибулы; $\mathrm{G}$ - максилла I; H - то же, дистальный край наружной доли; I — максилла II; J — максиллипед. 


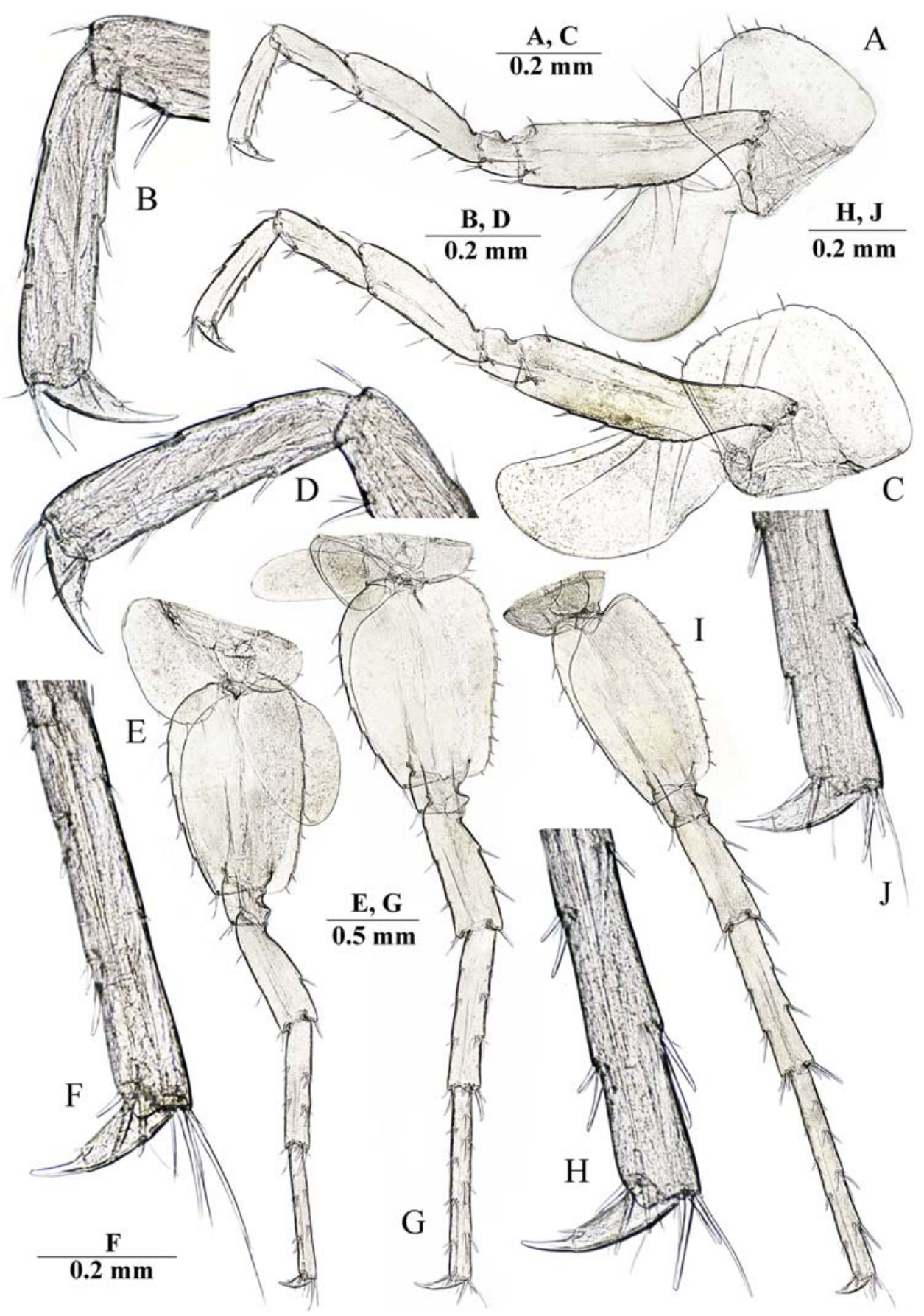

Fig. 19. Niphargus alisae sp.n., O': A — pereopod III; B — dactylus of PIII; C - pereopod IV; D — dactylus of PIV; E - pereopod V; F — dactylus of PV; G - pereopod VI; H - dactylus of PVI; I - pereopod VII; $\mathrm{J}$ - dactylus of PVII.

Рис. 19. Niphargus alisae sp.n., О7: А - переопод III. В - дактилус PIII; C - переопод IV; D дактилус PIV; E — переопод V; F — дактилус PV; G — переопод VI; H — дактилус PVI; I — переопод VII; J - дактилус VII. 
Euxinian relict amphipods in the subterranean fauna of the Northern Black Sea region 287

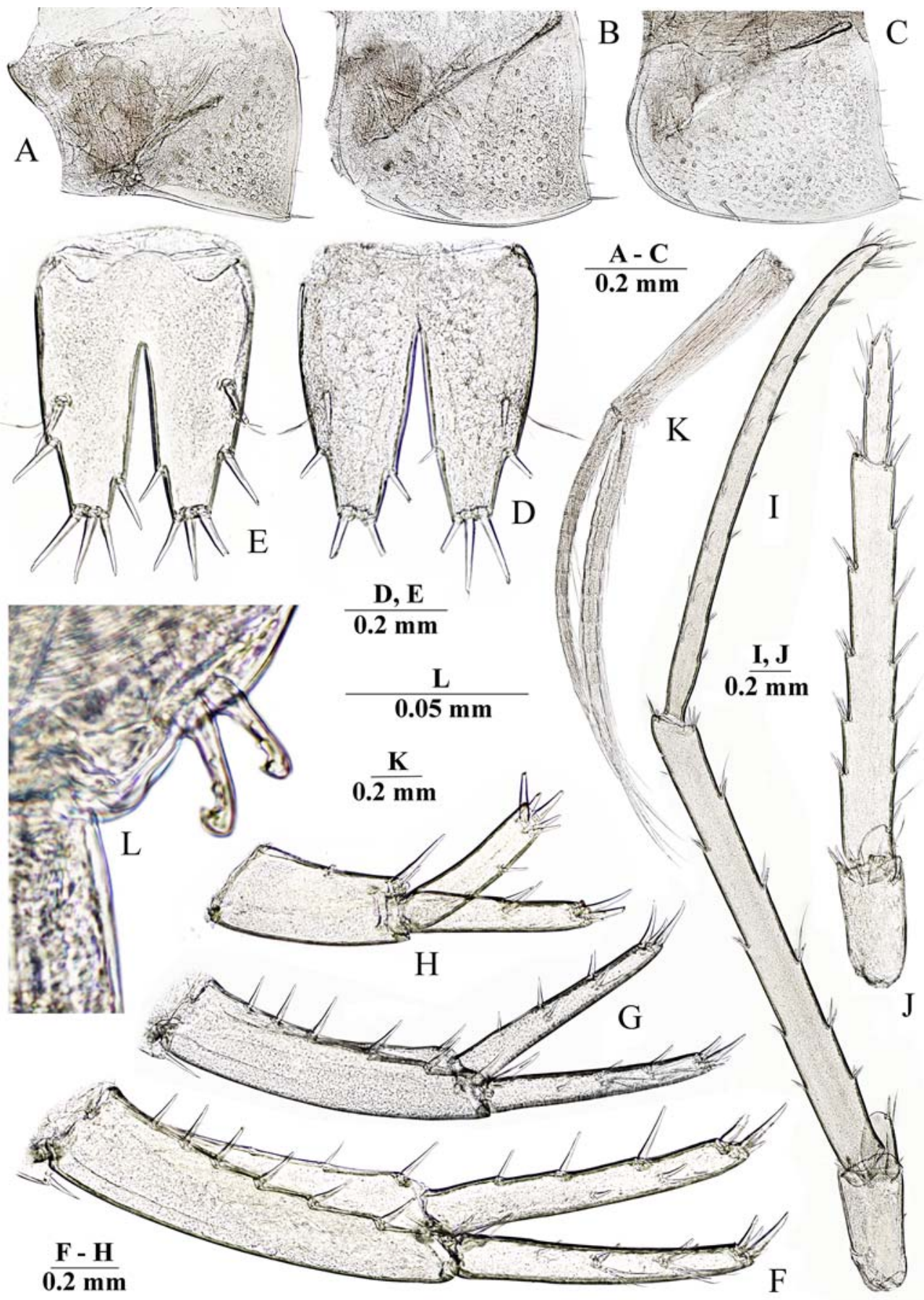

Fig. 20. Niphargus alisae sp.n., OT (A-D, F, H-I) and 9 (E, J, G): A-C - epimeral plates I-III; D-E - telson; F, G - uropod I; H - uropod II; I-J - uropod III; K - pleopod III; L - retinacula of pleopod III.

Pис. 20. Niphargus alisae sp.n., О (А-D, F, H-I) и + (E, J, G): А-C - эпимеральные пластинки I-III; D-E — тельсон; F, G - уропод I; H - уропод II; I-J — уропод III; K — плеопод III; L — ретинакула плеопод III. 
ing of 11 articles with relatively short setae; length of peduncle articles $4 / 5$ is $1 / 0.88$; flagellum is 0.74 times of length of peduncular articles $4+5$.

LABRUM (upper lip) (Fig. 18A): typical.

LABIUM (lower lip) (Fig. 18B): with entire, subrounded outer lobes and well-developed smaller inner lobes.

MANDIBLE (Fig. 18C, E): left mandible: incisor process with 5 teeth, lacinia mobilis with 4 teeth; with row of 8 serrated setae between lacinia and molar process, few spatulate setae and 1 long seta at base of molar (Fig. 18D); mandibular palp articles $2 / 3$ (distal) ratio is $1 / 1-$ 1.1; proximal article of palp without setae; article 2 with 10 setae; distal article with group of 6 A-setae; 3 groups of B-setae; 25 D-setae and 5 E-setae. Right mandible: incisor process with 4 teeth, lacinia mobilis bifurcate, with row of 8 serrated setae between lacinia and molar process (Fig. 18F).

MAXILLA I (Fig. 18G): inner lobe with 2 distal setae, outer lobe with 7 robust spines (6 spines with 1 strong lateral tooth each, inner spine with 5 small lateral teeth (1-1-1-1-1-15) (Fig. 18H)); palp 2-articulated, distal article with 5 simple setae distally.

MAXILLA II (Fig. 18I): both plates with numerous long distal simple setae, outer lobe with row of fine setae along outer margin.

MAXILLIPED (Fig. 18J): inner plate short, with 2 distal robust setae intermixed with 4 distal simple setae; outer plate reaching half of palpal article 2 and bearing row of 14-15 distolateral spines and distal setae; palpal article 3 with 1 median and 1 distal bunches of seta at outer margin; palpal article 4 with 1 median seta at outer margin; nail shorter than pedestal, with seta near basis.

GNATHOPOD I (Fig. 17D): basis elongated, with distal part greatly expanded; ischium with group of 5-6 posterodistal setae; merus subquadrate, equal to ischium; carpus is 0.50 0.52 of length of basis and 0.50 of length of propodus, with single distal group of setae anteriorly, with transverse rows of setae along posterior margin and row of setae posterolaterally; propodus subtrapezoidal, setose, with 8 rows of setae at posterior margin, anterior surface with 3 groups of total 5-7 setae each in addition to anterodistal group of 6-7 setae, several groups of short setae on inner surface, palmar corner armed with 1 long spiniform palmar seta, 3 serrated spiniform setae, single supporting spiniform seta on inner surface (Fig. 17E); dactylus with 6 setae along anterior margin, with row of short setae along inner surface; length of nail is 0.30 of total length of dactylus.

GNATHOPOD II (Fig. 17F): width/length ratio of basis is $0.28-0.30 / 1$, with 11 dorsolateral setae; ischium with 5 postero-distal setae; merus subquadrate, equal to ischium; carpus is 0.42 of length of basis and 0.55 of length of propodus, with distal group of setae anteriorly, few transverse rows of setae along posterior margin and row of setae posterolaterally; propodus subtrapezoidal, setose, larger than propodus of $\mathrm{GnI}(\mathrm{GnI} / \mathrm{II}$ as $0.79 / 1)$, posterior margin with 10 rows of setae, anterior surface with 2 group setae in addition to 6-7 anterodistal setae, with several groups of setae on inner surface, palmar corner with 1 strong palmar spiniform seta, single supporting spiniform seta on inner surface and 2 denticulated thick spiniform setae on outer side (Fig. 17G); dactylus with 5 setae along anterior surface and few short setae along inner surface; length of nail is about $0.29-0.30$ of total length of dactylus.

PEREOPODS III-IV (Fig. 19A, C): almost similar in size and shape; basis is 3.8-4.1 times as long as wide, with posterior margin bearing long marginal setae, with distoventral group of setae; ischium short, subquadrate, with distoventral group of setae; merus with slender simple setae along anterior and posterior surfaces; carpus/propodus ratio is $0.81-0.90$; propodus with 3 groups of spines along ventral margin; dactylus (Fig. 19B, D) relatively stout, curved, sharp distally, with 1 small additional posterior median spine and 1 median short plumose seta at outer margin; dactyli ratio of PpIII/IV is $1.15 / 1$; length of nail is $0.45-0.47$ of total length of dactylus.

PEREOPODS V-VII (Fig. 19E, G, I): length ratio of pereopods V/VI/VII is $1 / 1.51 / 1.58$; length of PVII is about half of total body length. 
PEREOPOD V (Fig. 19E): length/width ratio of basis is $1 / 0.64$, almost rectangular, with explicit posteroventral lobe; with facial setae; posterior margin slightly convex, with row of 12 slender marginal setae; anterior margin convex, with row of 6 slender marginal setae, which are distinctly longer than posterior ones, and group of setae in distal part; ischium subquadrate; merus with 2 bunches of slender spines along anterior surface and with 1 spine on posterior surface; carpus about as long as merus; propodus slender, 7.6 times as long as wide, with several bunches of short spines; dactylus (Fig. 21F) with 1 small additional posterior median spine and 1 median short plumose seta at outer margin.

PEREOPODS VI (Fig. 19G): length/width ratio of basis is $1 / 0.58$, with facial setae, posteroventral lobe and slightly concave posterior margin bearing row of 18 short marginal setae, anterior margin convex, with row of 6 longer marginal setae; merus with several bunches of short spines along anterior and posterior surfaces; carpus with group of spines intermixed with single short setae; propodus slender, about 11 times as long as wide, with several group of short spines; dactylus (Fig. 19H) slender, with 1 small additional posterior median spine and 1 short median plumose seta at outer margin.

PEREOPOD VII (Fig.19I): Male: length/ width ratio of basis is $1 / 0.58$, with posteroventral lobe and slightly convex posterior margin bearing row of 13 short marginal setae; with facial setae; anterior margin convex, with row of 5 longer marginal setae; carpus with 3 groups of short spines along anterior and posterior surfaces; propodus slender, about 9.5 times as long as wide, with several groups of short spines; dactylus (Fig. 19J) with 1 median spine and 1 seta at inner margin, and 1 short median plumose seta at outer margin. Female: length/width ratio of basis is $1 / 0.63$, with distinct posteroventral lobe and distinctly convex posterior margin bearing row of 13 short marginal setae; with facial setae; anterior margin convex, with row of 5 longer marginal setae; ishium about as long as wide; merus with several bunches of short spines along anterior and posterior margins; carpus with 3 groups of short spines along anterior and
2 groups along posterior margins; propodus slender, about 6.8 times as long as wide, with several groups of short spines; dactylus with 1 median spine and 1 seta at inner margin, and 1 short median plumose seta at outer margin.

PLEOPODS (Fig. 20K): pleopod I with basal segment armed with 2-3 small simple setae and 2 coupling hooks in retinacula; pleopod II with basal segments smooth, with 2 coupling hooks in retinacula; pleopod III with basal segment armed with 2-3 small and medium-sized simple setae and 2 coupling hooks accompanied by 1 large simple seta in retinacula (Fig. 20L).

UROPOD I (Fig. 20F-G): protopodite longer than rami, 4.1 times as long as wide, with dorsointernal row of 3 median setae and 1 subdistal spine, and dorsoexternal row of 6 spines; rami straight and subequal in length both in males and females, endopodite not paddle-like, with 3 dorsolateral and 2 mesial spines one of which accompanying by several (2-3) simple setae, 4 apical spines; exopodite with 2 mesial groups consisting of single spines accompanying by several (2-4) simple setae and also 1 single mesial spine; 4 apical spines.

UROPOD II (Fig. 20H): protopodite 1.92.0 times as long as wide, subequal rami; rami with lateral and distal slender spines, endopodite with 1 spine ventrolaterally, 5 spines apically; exopodite with 1 group consisting 2 spines dorsolaterally, 5 spines apically; exopodite/endopodite ratio is $1 / 1.12$.

UROPOD III (Fig. 20I-J): different in males and females, about 0.6 of body length in males and 0.4 in females. Male: protopodite 2.1 times as long as wide, with 1 lateral seta and 8-9 apical spiniform setae; rami unequal, endopodite short, about 15 times shorter than exopodite, with 1 small simple seta an laterally and 2 setae subapically, including 1 spiniform and 1 long plumose seta; distal article is 1.07 of length of proximal article, with 8-9 groups of thin-flexible setae along each margin and group of simple setae apically; proximal article with 5 groups of thin-flexible, plumose and spiniform setae along inner and outer margins. Female: protopodite 1.9-2.0 times as long as wide, with 2 lateral setae and 8-9 apical spiniform setae; rami un- 
equal, endopodite short, about 9.0-9.1 times shorter than exopodite, with 1 small simple seta and 1 plumose seta laterally, 1 subapical spiniform seta; distal article is 0.34 of length of proximal article, with 3 groups of thin-flexible setae along each margin and group of simple setae apically; proximal article with 4 groups of spiniform and thin-flexible setae along outer margin and 5 groups of thin-flexible, plumose and spiniform setae along inner margin.

TELSON (Fig. 20D-E): length/width ratio is $1 / 0.85-0.89$; cleft is $0.66-0.72$ of length of telson; margins straight, narrowing apically; with variable armature, including 3 medium distal spines on each lobe, 1 lateral spine, accompanying by 2 plumose setae on each outer margins, 1 spine on inner margins on each side, 1 sublateral spine and 1-2 small mesial setae on dorsal surface; apical spiniform setae are 0.30 of length of telson.

COLORATION. Body, appendages and internal organs are whitish or yellowish characteristic of stygobiotic representatives of the genus.

BODY SIZE. The largest collected + has tbl. $7.0 \mathrm{~mm}$; the largest collected $\sigma^{7}$ has tbl. $9.5 \mathrm{~mm}$.

GENBANK (NCBI) ACCESSION NUMBERS. MZ382410-MZ382415.

TAXONOMIC REMARKS. Niphargus alisae sp.n. is morphologically close and phylogenetically related to $N$. utrishensis sp.n. and $N$. novorossicus sp.n. (Fig. 1), but it can be separated from the latter and related species of the "tauricus" ingroup (see Table 1) by 1) a relatively short antenna I with 22 artciles (vs. 26-28 articles in other species); 2) a relatively longer propodus of pereopod VI with length/width ratio is about 0.91 (vs. about $0.76-0.93$ in other species); and 3) a wider telson with length/width ratio is about $1 / 0.85-0.89$.

ETYMOLOGY. The species is named after Dr. Alisa R. Kosyan (14.07.1981-17.06.2020), who lived and studied marine fauna of the Black Sea in the Golubaya Bukha region of the Gelendzhik City, very close to the habitat of this species. In the area of the Shel 1 and the Shel 2 of the Doob Mount; she loved to swim in the sea.

ECOLOGY AND DISTRIBUTION. Niphargus alisae sp.n. inhabits various water sources (springs, spring pools, wells, streams and river hyporhea) in the area of Doob Mountain (Kabardinka area), or usually called the Tuaphat Ridge, of the Doob Peninsula (Krasnodar Krai) (Figs 2; 3). This mountain is considered as a part of the Navagirsky Ridge, but separated by the Tsemes (=Tsemesskaya, Novorossiyskaya) Bay of the Black Sea, formed as a result of karst collapse (Trikhunkov et al., 2018).

\section{Niphargus ashamba Marin, Krylenko et Palatov sp.n.}

Figs 21-24; 33D.

MATERIAL EXAMINED. HOLOTYPE, $\mathrm{O}^{7}$ (b1. $9.5 \mathrm{~mm}$ ) (ZMMU Mb-1190), NW slope of Tuapkhat Ridge, st. $85,44^{\circ} 36.435^{\prime} \mathrm{N}, 38^{\circ} 0$. $073^{\prime} \mathrm{E}$, about $65 \mathrm{~m}$ a.s.1., stream in the valley of the Ashamba River, hand net sampling, coll. S. Krylenko, 7.01.2018. PARATYPES. $2 \sigma^{\top} \sigma^{\top}$ (bl. 7.0, $8.5 \mathrm{~mm}$ ), 3우 (bl. 6.5-7.0 mm) (ZMMU Mb-1191), same data and locality as holotype.

ADDITIONAL MATERIAL. RUSSIA, Southwestern Caucasus, Krasnodar Krai, Gelendzhik area: $2 \sigma^{\top} \sigma^{\top}, 1+, \mathrm{N}$ slope of Tuapkhat Ridge, $44^{\circ} 37.870^{\prime} \mathrm{N}, 38^{\circ} 01.823^{\prime} \mathrm{E}$, about $200 \mathrm{~m}$ a.s.l., stream in the valley of the Ashamba River, hand net sampling, coll. S. Krylenko, 7.01.2018; $20^{7} \sigma^{7}, 7+9$ (LEMMI), N slope of the Tuapkhat Ridge, $44^{\circ} 37.191^{\prime} \mathrm{N}, 37^{\circ} 58.564^{\prime} \mathrm{E}$, about $80 \mathrm{~m}$ a.s.l., stream in the valley of the Ashamba River, hand net sampling, coll. S. Krylenko, 5.01.2018; 1 ( (LEMMI), S slope of the Markotkh Ridge, $44^{\circ} 39.456^{\prime} \mathrm{N}, 38^{\circ} 0.406^{\prime} \mathrm{E}$, about $221 \mathrm{~m}$ a.s.1., stream in the valley of the Ashamba River, hand net sampling, coll. S. Krylenko, 7.01.2018; $10^{7}$ (LEMMI), S slope of the Markotkh Ridge, $44^{\circ} 39.732^{\prime} \mathrm{N}, 37^{\circ} 55.895^{\prime} \mathrm{E}$, about $55 \mathrm{~m}$ a.s.1., stream in the valley of the Doob River, hand net sampling, coll. S. Krylenko, 5.12.2018; $20^{\top} \sigma^{\top}$, $2+0$ (LEMMI), S slope of the Markotkh Ridge, $44^{\circ} 40.784^{\prime} \mathrm{N} 37^{\circ} 55.517^{\prime} \mathrm{E}$, about $175 \mathrm{~m}$ a.s.l., small stream, hand net sampling, coll. S. Krylenko, 5.12.2018; $2 \sigma^{7} \sigma^{7}$ (LEMMI), S slope of the Markotkh Ridge, $44^{\circ} 37.535^{\prime} \mathrm{N}, 38^{\circ} 01.397^{\prime} \mathrm{E}$, about $118 \mathrm{~m}$ a.s.l., stream in the valley of the Ashamba River, hand net sampling, coll. S. 
Krylenko, 7.01.2018; 1 + (LEMMI), S slope of the Markotkh Ridge, $44^{\circ} 39.117^{\prime} \mathrm{N}, 38^{\circ} 01.0^{\prime} \mathrm{E}$, about $300 \mathrm{~m}$ a.s.1., stream in the valley of the Ashamba River, hand net sampling, coll. S. Krylenko, 7.01.2018; 7우, $10^{7}$ (LEMMI), a small tributary of the Ashamba River, $44^{\circ} 36$. $484^{\prime} \mathrm{N} 37^{\circ} 58.387^{\prime} \mathrm{E}$, about $145 \mathrm{~m}$ a.s.1., inside a small spring flowing, hand net sampling, coll. V. Krylenko, 3.03.2021.

DESCRIPTION.

BODY: depigmented, moderately slender.

HEAD: length is approximately $10 \%$ of body length; rostrum and pigmented spots on anterior lobe absent, with subrounded lateral cephalic lobes and excavated anteroventral sinus.

PEREON: pereonites I-VII without setae, smooth.

PLEOSOMA: pleonites I-III with several short marginal setae on each posterodorsal margin.

EPIMERAL PLATES: posteroventral corners of epimeral plates I-III nearly right-angled, slightly rounded (Fig. 24A-C). Epimeral plate I: posterior and ventral margin slightly convex; without spines along ventral margin; with 4 setae along posterior margin; posteroventral angle with 1 strong seta. Epimeral plate II: posterior margin slightly concaved, ventral margin slightly convex; with 2 spiniform setae along ventral margin; 6 setae along posterior margin; posteroventral angle with 1 strong seta. Epimeral plate III: posterior margin slightly concave, ventral margin slightly convex; with 2 spiniform setae along ventral margin; with 7 setae along posterior margin; posteroventral angle with 1 strong seta.

UROSOMITES (Fig. 33D): urosomite I with 1 spine accompanying 1 simple seta on each side dorsolaterally, with 1 posteroventral spines near basis of uropod I dorsolaterally; urosomite II with 3 simple strong spines on each side dorsolaterally; urosomite III unarmed.

COXAE (Figs 21D, F; 23A, C, E, G, I): coxal plate I oval, with rounded anteroventral corner, armed with 6 setae; width/depth ratio is $0.76 / 1$; width/depth ratio of coxal plates II-IV are $0.96 / 1,1 / 1$ and $1 / 1.1$, respectively; anterior and ventral margins of coxal plates II-IV with
11,13 and 10 setae respectively; with rounded anteroventral corners; coxal plates V-VI with large lobes anteriorly, posterior margins with 3 setae each; anterior margins with 5 and 0 setae respectively; coxal plate VII trapezoid, with concave ventral margin; posterior lobe with 1 seta; coxal gills II-VI ovoid, length gills/bases ratio of pereopods are $0.58 / 1,0.85 / 1,0.9 / 1$, $0.88 / 1$ and $0.7 / 1$, respectively.

ANTENNAI(Fig. 21A): slender, about 0.580.6 of body length; peduncular articles moderately slender, ratio is $1 / 0.87 / 0.46$; flagellum with 28 articles, most of them with 2 short aesthetascs each; accessory flagellum short, 2-articulated (Fig. 21b); antennas I/II ratio is $1 / 0.55$.

ANTENNA II (Fig. 21C): peduncular articles moderately stout, with several long setae along ventral margin, dorsal setae shorter than inner ones; flagellum relatively short, consisting of 12 articles with relatively short setae; length of peduncle articles $4 / 5$ is $1 / 0.96$; flagellum is 0.7 times of length of peduncular articles $4+5$.

LABRUM (upper lip) (Fig. 22A): typical.

LABIUM (lower lip) (Fig. 22B): with entire, subrounded outer lobes and well developed smaller inner lobes.

MANDIBLE (Fig. 22C, E): left mandible: incisor process with 5 teeth, lacinia mobilis with 4 teeth; with row of 8 serrated setae between lacinia and molar process, few spatulate setae and one long seta at base of molar (Fig. 22D); mandibular palp article $2 / 3$ (distal) ratio is $1 / 1-1.28$; proximal article of palp without setae; article 2 with 14 setae; distal article with group of 6 A-setae; 2 groups of B-setae; 26 Dsetae and 5 E-setae (Fig. 22C, E). Right mandible: incisor process with 4 teeth, lacinia mobilis bifurcate, with row of 8 serrated setae between lacinia and molar process (Fig. 22F).

MAXILLA I (Fig. 22G): inner lobe with 2 distal setae, outer lobe with 7 robust spines (6 spines with 1 strong lateral tooth each, inner spine with 4 small lateral teeth (1-1-1-1-1-14) (Fig. 22H)); palp 2-articulated, distal article with 5 simple setae distally.

MAXILLA II (Fig. 22I): both plates with numerous long distal simple setae, outer lobe with row of fine setae along outer margin. 

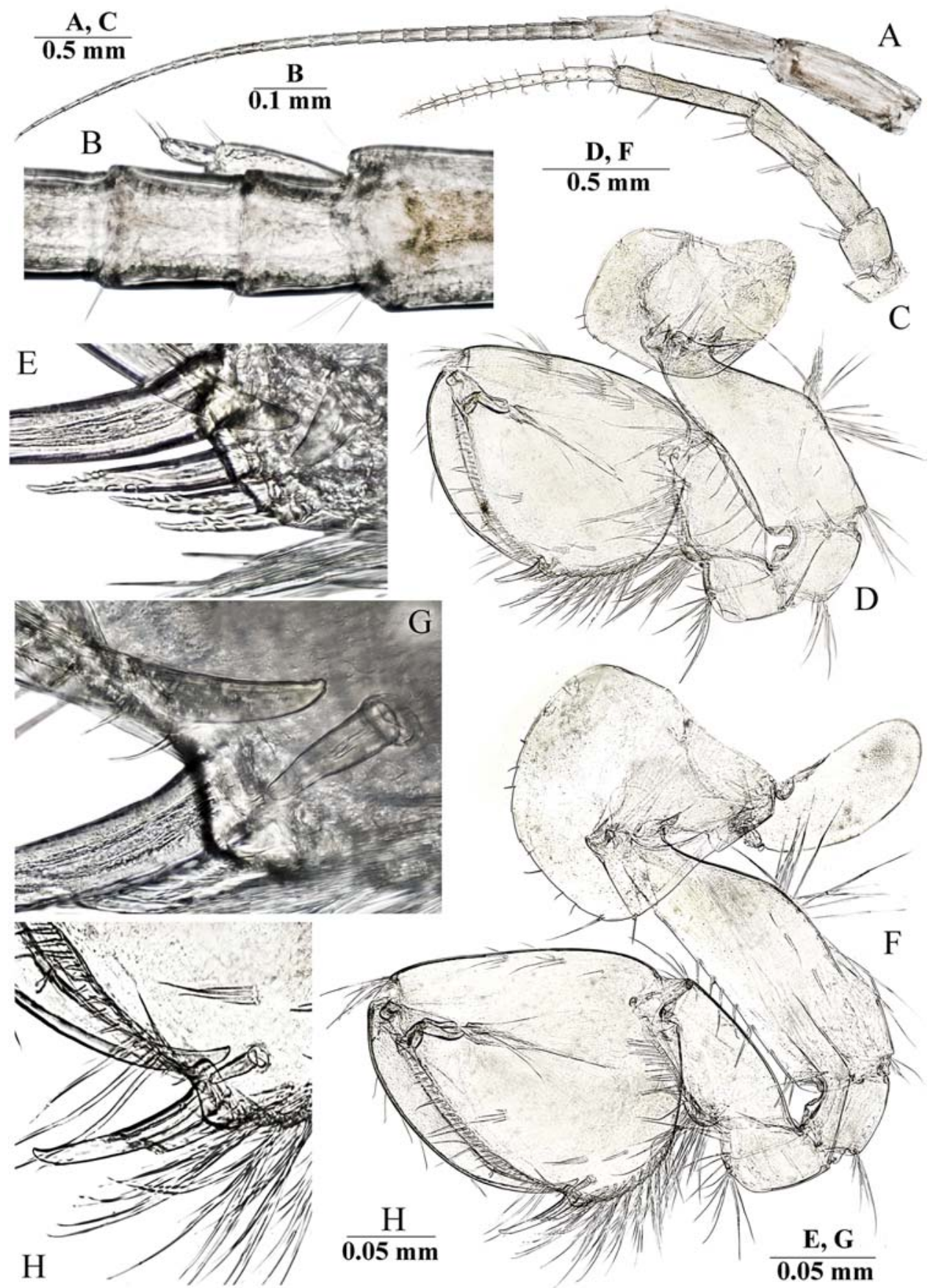

Fig. 21. Niphargus ashamba sp.n., O': A — antenna I; B — accessory flagellum of antenna I; C — antenna II; D - gnathopod I; E — distoventral corner of GnI; F — gnathopod II; G-H - distoventral corner of chela of GnII.

Fig. 21. Niphargus ashamba sp.n., O': А — антенна I; В - дополнительный жгутик антенны I; C антенна II; D - гнатопод I; E — дистовентральный угол клешни GnI; F - гнатопод II; G дистовентральный угол клешни GnII. 
Euxinian relict amphipods in the subterranean fauna of the Northern Black Sea region 293
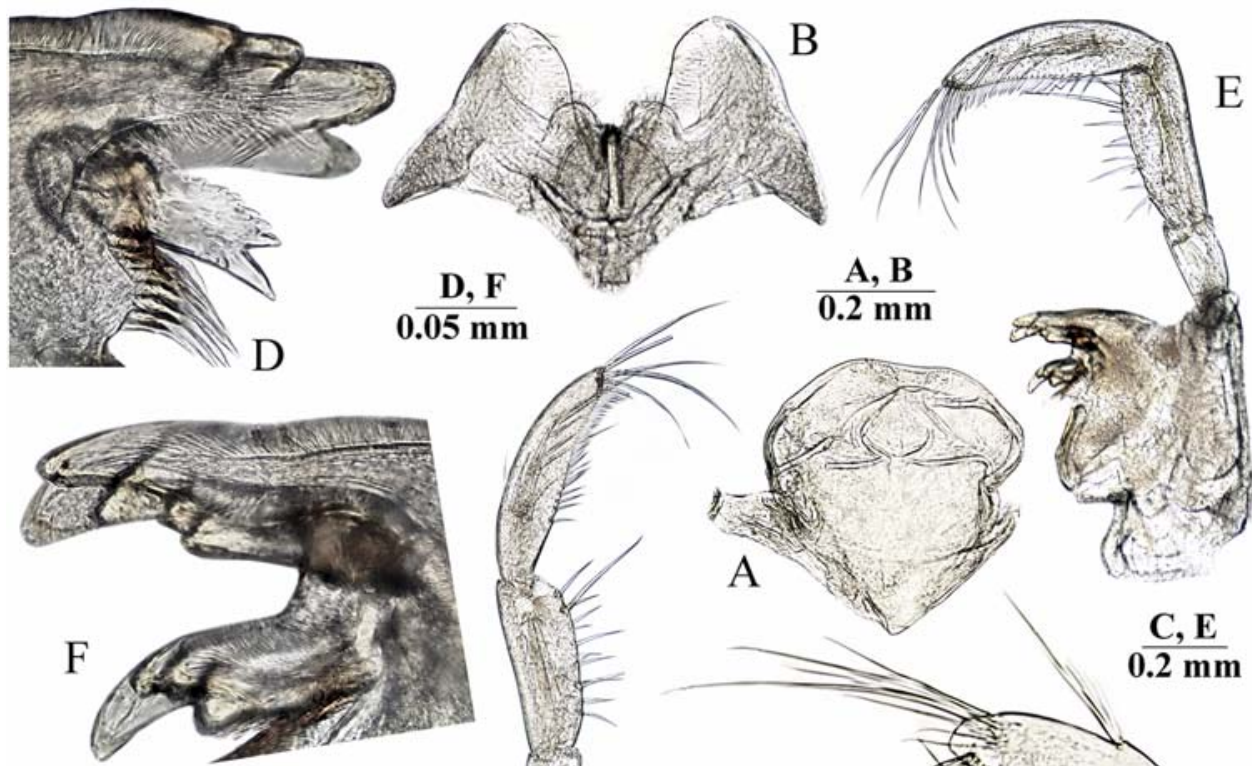

$0.2 \mathrm{~mm}$
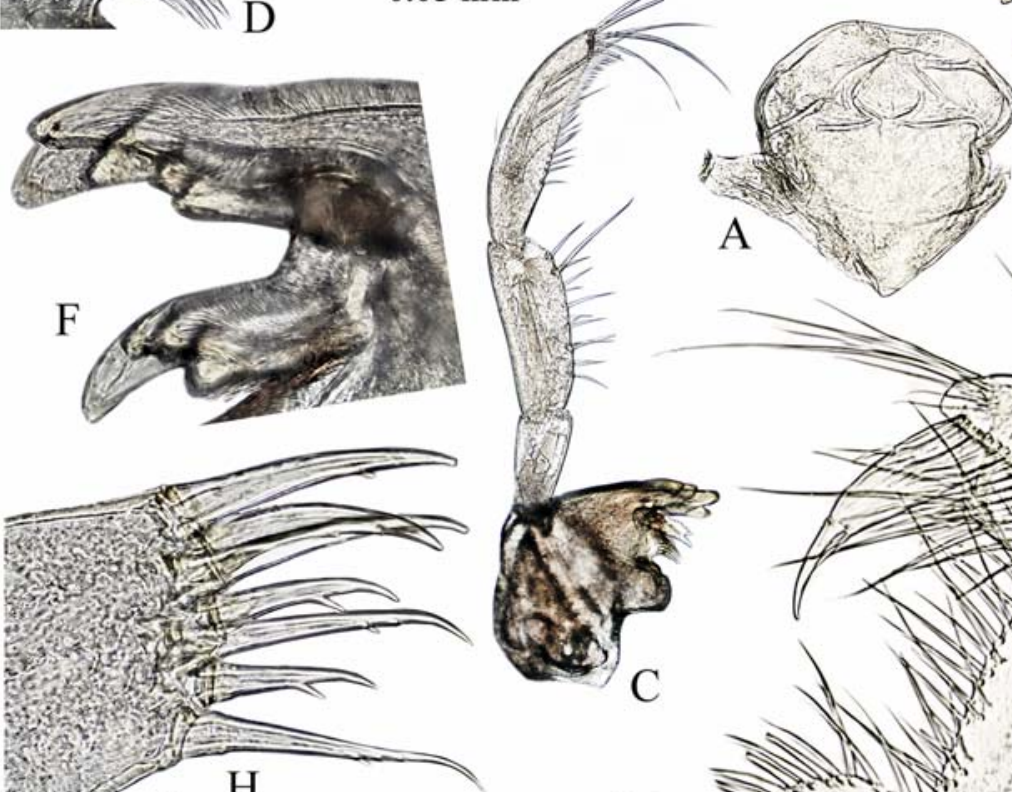

A

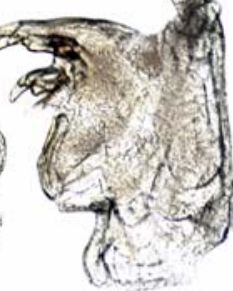

C, $\mathbf{E}$
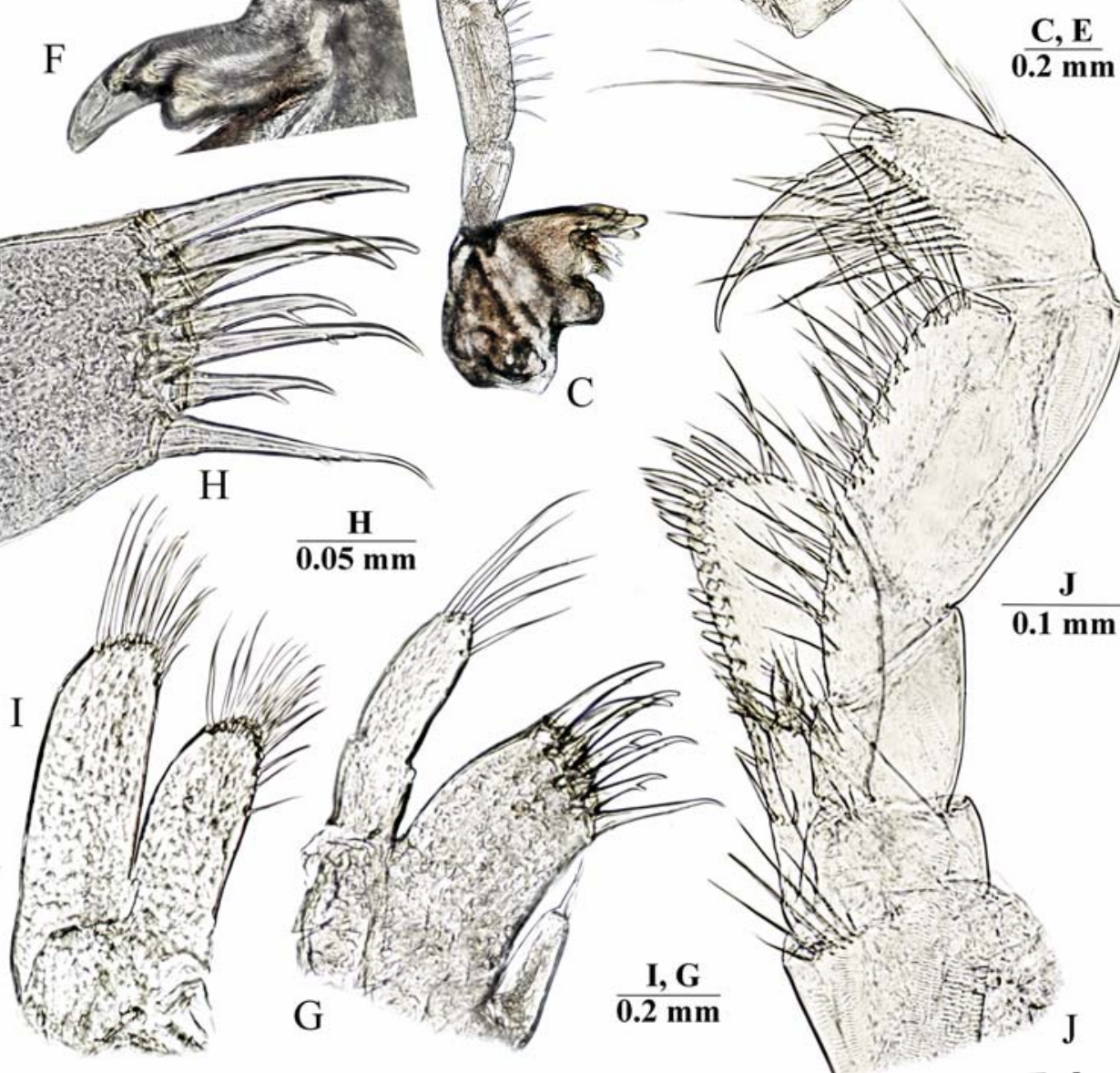

Fig. 22. Niphargus ashamba sp.n., O': A - labrum (upper lip); B - labium (lower lip); C, E - mandible; $\mathrm{D}, \mathrm{F}$ - incisor process and pars incisiva of mandibles; $\mathrm{G}$ - maxilla I; H — same, distal margin of outer lobe; I - maxilla II; J - maxilliped.

Рис. 22. Niphargus ashamba sp.n., Oج: А — верхняя губа; В - нижняя губа; C, Е - мандибула; D, F режущий отросток и pars incisiva (резец) мандибулы; $\mathrm{G}$ - максилла I; H - то же, дистальный край наружной доли; I — максилла II; J — максиллипед. 


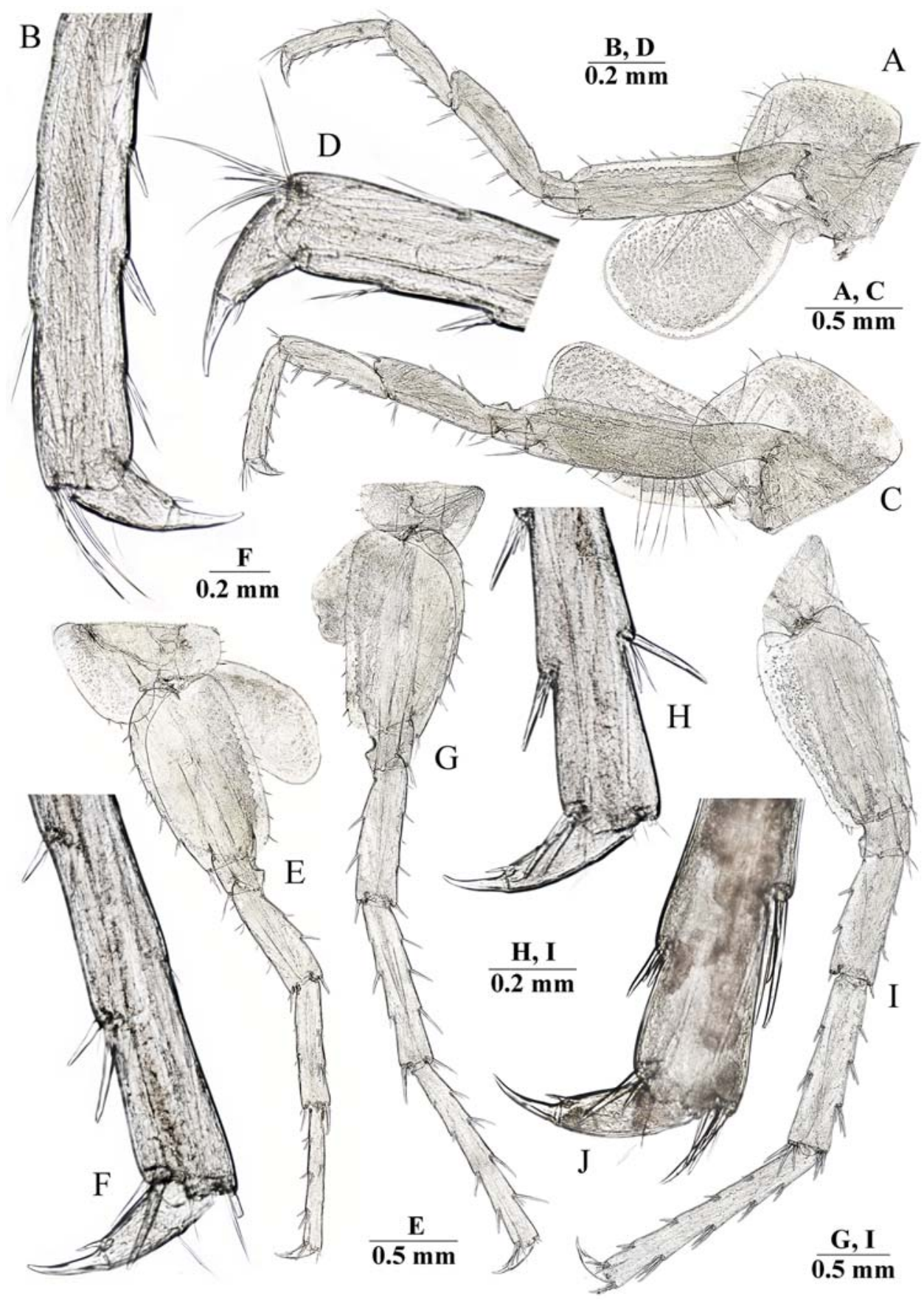

Fig. 23. Niphargus ashamba sp.n., O: A - pereopod III; B — dactylus of PIII; C - pereopod IV; D dactylus of PIV; E - pereopod V; F - dactylus of PV; G - pereopod VI; H - dactylus of PVI; I pereopod VII; J - dactylus of PVII.

Рис. 23. Niphargus ashamba sp.n., Оج: A - переопод III. В - дактилус PIII; C - переопод IV; D дактилус PIV; E — переопод V; F — дактилус PV; G — переопод VI; H — дактилус PVI; I — переопод VII; J - дактилус VII. 
Euxinian relict amphipods in the subterranean fauna of the Northern Black Sea region 295

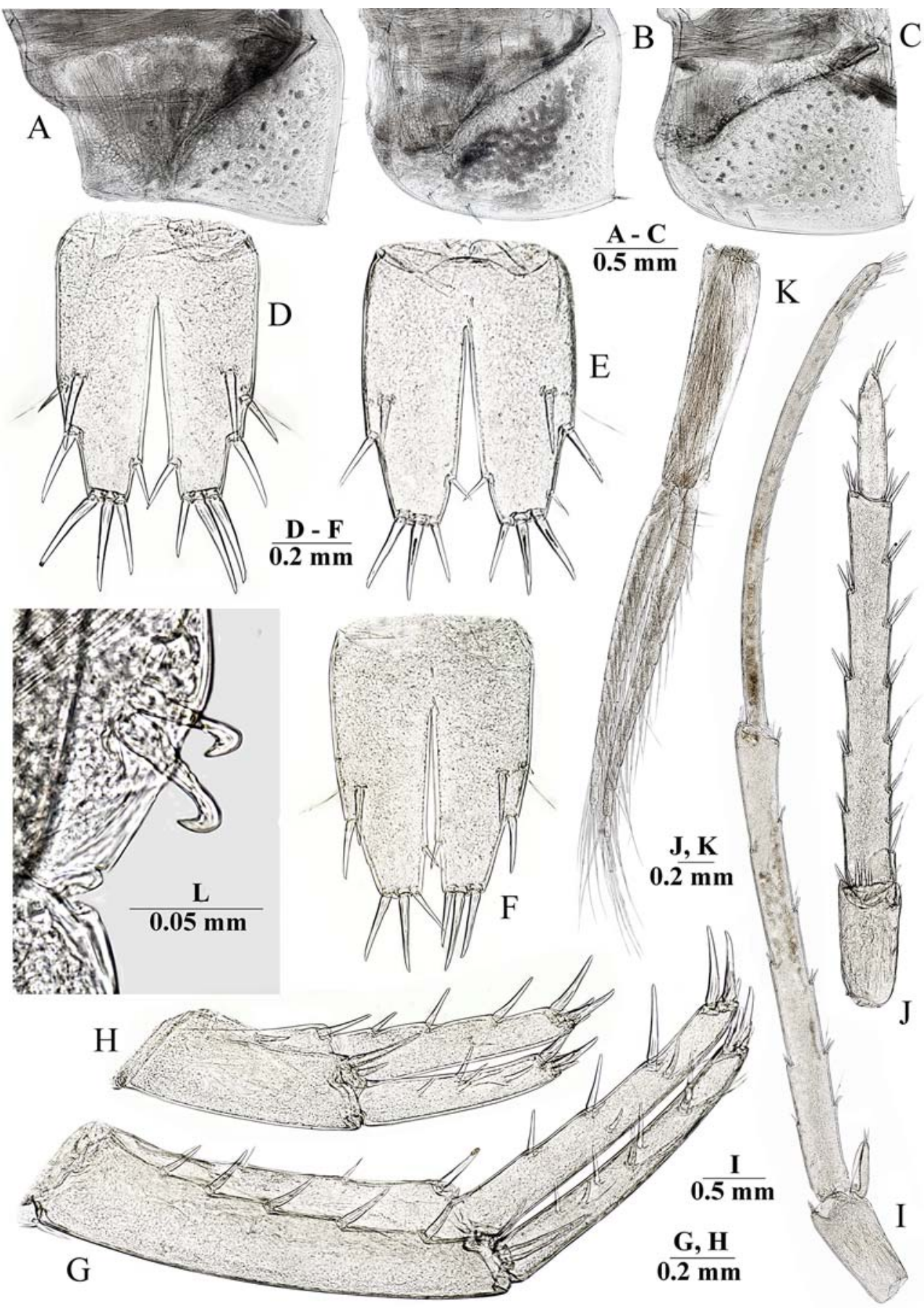

Fig. 24. Niphargus ashamba sp.n., Oج: (A-D, F-I) and $\odot$ (E, J): A-C - epimeral plates I-III; D-F - telson; $\mathrm{G}$ - uropod I; H - uropod II; I-J - uropods III; K - pleopod III; L - retinacula of pleopod III.

Рис. 24. Niphargus ashamba sp.n., O $^{7}$ (A-D, F-I) и D-F — тельсон; G - уропод I; H - уропод II; I-J — уропод III; K — плеопод III; L — ретинакула плеопод III. 
MAXILLIPED (Fig. 22J): inner plate short, with 3 distal robust setae intermixed with 6 distal simple setae; outer plate reaching half of palpal article 2 and bearing row of 20-21 distolateral spines and distal setae; palpal article 3 with 1 median and 1 distal bunches of seta at outer margin; palpal article 4 with 1 median seta at outer margin; nail shorter than pedestal, with 2 setae near basis.

GNATHOPOD I (Fig. 21D): basis elongated, with distal part greatly expanded; ischium with group of 7 posterodistal setae; merus subquadrate, equal to ischium; carpus is $0.49-0.50$ of length of basis and 0.5 of length of propodus, with single distal group of setae anteriorly, with transverse rows of setae along posterior margin and row of setae posterolaterally; propodus subtrapezoidal, setose, with 8 rows of setae at posterior margin, anterior surface with 3 groups of total 5-8 setae each in addition to anterodistal group of 6-7 setae, several groups of short setae on inner surface, palmar corner armed with 1 long spiniform palmar seta, 3 serrated spiniform setae, single supporting spiniform seta on inner surface (Fig. 21E); dactylus with 5 setae along anterior margin, with row of short setae along inner surface; length of nail is 0.32 of total length of dactylus.

GNATHOPOD II (Fig. 21F): width/length ratio of basis is $0.31 / 1$, with 10 dorsolateral setae; ischium with 8 posterodistal setae; merus subquadrate, equal to ischium; carpus is 0.48 of length of basis and 0.59 of length of propodus, with distal group of setae anteriorly, few transverse rows of setae along posterior margin and row of setae posterolaterally; propodus subtrapezoidal, setose, larger than propodus of GnI $(\mathrm{GnI} / \mathrm{II}$ as $0.91 / 1)$, posterior margin with 10 rows of setae, anterior surface with 2 group setae in addition to 8 anterodistal setae, with several groups of setae on inner surface, palmar corner with 2 strong palmar spiniform setae, single supporting spiniform seta on inner surface and 2 denticulated thick spiniform setae on outer side (Fig. 21G-H); dactylus with 6 setae along anterior surface and few short setae along inner surface; length of nail is about 0.35 of total length of dactylus.
PEREOPODS III-IV (Fig. 23A, C): almost similar in size and shape; basis is 4.1-4.2 times as long as wide, with posterior margin bearing long marginal setae, with distoventral group of setae; ischium short, subquadrate, with distoventral group of setae; merus with slender simple setae along anterior and posterior surfaces; carpus/propodus ratio is $0.93-0.97 / 1$; propodus with 4 groups of spines along ventral margin; dactylus (Fig. 23B, D) relatively stout, curved, sharp distally, with 1 small additional posterior median spine and 1 median short plumose seta at outer margin; dactyli ratio of PpIII/IV is 1/ 1.05 ; the length of nail is $0.42-0.43$ of total length of dactylus.

PEREOPODS V-VII (Fig. 23E, G, I): length ratio of $\mathrm{PpV} / \mathrm{VI} / \mathrm{VII}$ is $1 / 1.37 / 1.56$; length of PVII is about half of total body length.

PEREOPOD V (Fig. 23E): length/width ratio of basis is $1 / 0.58$, almost rectangular, with feebly marked posteroventral lobe; with facial setae; posterior margin slightly convex, with row of 13 slender marginal setae; anterior margin convex, with row of 8 slender marginal setae, which are distinctly longer than posterior ones, and group of setae in distal part; ischium subquadrate; merus with 3 bunches of slender spines along anterior surface and with 2 spines on posterior surface; propodus slender, 8.7-8.8 times as long as wide, with several bunches of short spines; dactylus (Fig. 23F) with 1 small additional posterior median spine and 1 median short plumose seta at outer margin.

PEREOPOD VI (Fig. 23G): length/width ratio of basis is $1 / 0.56$, with facial setae, distinct posteroventral lobe and slightly concave posterior margin bearing row of 15 short marginal setae, anterior margin convex, with row of 7 longer marginal setae; merus with several bunches of short spines along anterior and posterior surfaces; carpus with group of spines intermixed with single short setae; propodus slender, about 7.87.9 times as long as wide, with several group of short spines; dactylus (Fig. 23H) slender, with 1 small additional posterior median spine and 1 short median plumose seta at outer margin.

PEREOPOD VII (Fig. 23I): male: length/ width ratio of basis is $1 / 0.53$, with distinct 
posteroventral lobe and slightly concave posterior margin bearing row of 15 short marginal setae; with facial setae; anterior margin convex, with row of 7 longer marginal setae; ishium about as long as wide; merus with several bunches of short spines along anterior and posterior margins; carpus with 3 groups of short spines along anterior and 2 groups along posterior margins; propodus slender, about 8.2-8.3 times as long as wide, with several groups of short spines; dactylus (Fig. 23J) with 1 median spine and 1 seta at inner margin, and 1 short median plumose seta at outer margin.

PLEOPODS (Fig. 24K): pleopod I with basal segment armed with 2 simple setae and 2 coupling hooks in retinacula; pleopod II with basal segments smooth, with 2 coupling hooks in retinacula; pleopod III with basal segment armed with 2-3 small and medium-sized simple setae and 2 coupling hooks in retinacula (Fig. 24L).

UROPOD I (Fig. 24G): protopodite longer than rami, 3.9-4 times as long as wide, with dorsointernal row of 3 median setae and one subdistal spine, and dorsoexternal row of 5 spines; rami straight and subequal in length both in males and females, endopodite not paddlelike, with 3 dorsolateral and 2 mesial spine one of which accompanying by several (2-3) simple setae, 4 apical spines; exopodite with 3 mesial groups consisting of single spines accompanying by several (1-3) simple setae and also 1-2 single dorsolateral spines, 4 apical spines.

UROPOD II (Fig. 24H): protopodite 2.22.3 times as long as wide; exopodite/endopodite ratio length is $1 / 1.12$; rami with lateral, mesial and distal slender spines, endopodite with 3 single spines dorsolaterally and 1 spine mesially, 4 spines apically; exopodite with 1 single spine dorsolaterally, 3 spines mesially, one of which accompanying by several (1-3) simple setae; 4 spines - apically.

UROPOD III (Fig. 24I, J): different in males and females, about $0.56-0.58$ of body length in males and $0.36-0.37$ in females. Male: protopodite 2.0 times as long as wide, with $0-1$ lateral seta and 8-9 apical spiniform setae; rami unequal, endopodite short, about 17-17.5 times shorter than exopodite, with $0-1$ small simple seta laterally and 2-3 setae apically, including 1-2 spiniform and 1 long plumose setae; distal article is 1.03 of length of proximal article, with 10 groups of thin-flexible setae along each margin and group of simple setae apically; proximal article with 4 groups of spiniform setae along outer margin and 5 groups of thin-flexible, plumose and spiniform setae along inner margin. Female: protopodite 2.0 times as long as wide, with 2 lateral setae and 6-7 apical spiniform setae; rami unequal, endopodite short, about 9.6 times shorter than exopodite, with 1 small simple and 1 spiniform seta laterally and 2 setae apically, including 1 spiniform and 1 plumose seta; distal article is 0.33 of length of proximal article, with 2-3 groups of thin-flexible setae along each margin and group of simple setae apically; proximal article with 4-5 groups of spiniform setae along outer margin and 6-7 groups of thin-flexible, plumose and spiniform setae along inner margin.

TELSON (Fig. 24D-F): length/width ratio is $1 / 0.75-0.81$; cleft is $0.68-0.75$ of length of telson; margins straight or weakly rounded, narrowing apically; with variable armature, including 3 medium distal spines on each lobe, 1-2 lateral spines, one of which accompanying by 2 plumose setae on each outer margins; 1 spine on inner margins; dorsal surface with 1 submarginal spine on each side and 1-2 small mesial setae; apical spiniform setae are $0.30-0.37$ of length of telson.

COLORATION. Body, appendages and internal organs are whitish or yellowish characteristic of stygobiotic representatives of the genus.

BODY SIZE. The largest collected $q$ has tbl. $7.0 \mathrm{~mm}$; the largest collected $\sigma^{7}$ has tbl. $9.5 \mathrm{~mm}$.

GENBANK (NCBI) ACCESSION NUMBERS. MZ382416-MZ382419.

TAXONOMIC REMARKS. Niphargus ashamba sp.n. can be separated from related species of the "tauricus" ingroup (see Table 1) by 1 ) a relatively long antenna II with 28 articles; 2 ) a relatively long propodus of pereopod $\mathrm{V}$ with length/width ratio is about 8.7-8.8; and 3 ) the absence of plumose setae in retinacula of pleopod III (vs. present in other species of the group). 
ETYMOLOGY. The species is named after the Ashamba River (Gelendzhik area of Krasnodar Krai, Russia), where it was firstly discovered.

ECOLOGY AND DISTRIBUTION. The new species inhabits springs and hyporhea of small rivers that flow from the southern side of the Markotkh Ridge in the area of the Doob Peninsula, in several small springs on the northeastern slope of the Tuaphat Ridge of the Doob Peninsula, as well as the hyporhea of the Ashamba River, usually found under large stones and boulders as well as in sunken fallen leaves.

\section{Niphargus malakhovi Marin et Palatov sp.n.} Figs 25-28; 33G.

MATERIAL EXAMINED. HOLOTYPE, † (bl. $8.5 \mathrm{~mm}$ ) (ZMMU Mb-1194), RUSSIA, Krasnodar Krai, SE slope of the Great Caucasian Ridge, Gelendzhik Urban area, Doguab River basin, Mikhailovskiy Pass, $44^{\circ} 31.449^{\prime} \mathrm{N}$, $38^{\circ} 17.650^{\prime} \mathrm{E}$, about $158 \mathrm{~m}$ a.s.l., the Natashka Spring near the Mikhailovsky Pereval village, hand net sampling, coll. I. Marin \& D. Palatov, 20.04.2018. PARATYPES, 4 우 (bl. 4.0-6.0 $\mathrm{mm}$ ) (ZMMU Mb-1195), same locality and same data as holotype.

ADDITIONAL MATERIAL. RUSSIA, Krasnodar Krai, SE slope of the Great Caucasian Ridge, Gelendzhik Urban area: $1+$ (bl. 8.5 mm) (LEMMI), Mikhailovsky Pass, Doguab River basin, $44^{\circ} 31.449^{\prime} \mathrm{N}, 38^{\circ} 17.650^{\prime} \mathrm{E}$, about $158 \mathrm{~m}$ a.s.l., the Natashka Spring near the Mikhailovsky Pereval village, hand net sampling, coll. D. Palatov, 23.07.2020; 3 우 (LEMMI), Hotecay, $44^{\circ} 28.638^{\prime} \mathrm{N}, 38^{\circ} 09.313^{\prime} \mathrm{E}$, about $192 \mathrm{~m}$ a.s.1., a spring in the valley of the Hotecay River, hand net sampling, coll. S. Krylenko, 6.12.2018; 5우 (LEMMI), Dgankhot, $44^{\circ} 28$. $515^{\prime} \mathrm{N}, 38^{\circ} 11.893^{\prime} \mathrm{E}$, about $223 \mathrm{~m}$ a.s.l., stream in the valley of the Dgankhot River, hand net sampling, coll. S. Krylenko, 6.12.2018; 4우 (LEMMI), road between Krynica and Betta, $44^{\circ} 22.672^{\prime} \mathrm{N}, 38^{\circ} 21.938^{\prime} \mathrm{E}$, about $60 \mathrm{~m}$ a.s.1., inside a small spring flowing into Black Sea, hand net sampling, coll. S. Krylenko, 6.12.2018.

DESCRIPTION.

BODY: depigmented, moderately slender.
HEAD: length is approximately $10 \%$ of body length; rostrum and pigmented spots on anterior lobe absent, with subrounded lateral cephalic lobes and excavated anteroventral sinus.

PEREON: pereonites I-VII without setae, smooth.

PLEOSOMA: pleonites I-III with several short marginal setae on each posterodorsal margin.

EPIMERAL PLATES: posteroventral corners of epimeral plates I-II nearly right-angled, slightly rounded; posteroventral corners of epimeral plates III bluntly pointed shaped (Fig. $28 \mathrm{~A}-\mathrm{C}$ ). Epimeral plate I: posterior and ventral margins slightly convex; without spines along ventral margin; with 5 setae along posterior margin; posteroventral angle with 1 strong seta. Epimeral plate II: posterior margin straight, ventral margin slightly convex; with 1 spiniform seta on ventral margin; 6 setae along posterior margin; posteroventral angle with 1 strong seta. Epimeral plate III: posterior margin oblique, ventral margin slightly convex; with 3 spiniform setae along ventral margin; with 7 setae along posterior margin; posteroventral angle with 1 strong seta.

UROSOMITES (Fig. 33G): urosomite I with 1 spine on each side dorsolaterally, with 1 posteroventral spines near basis of uropod I dorsolaterally; urosomite II with 3 simple strong spines on each side dorsolaterally; urosomite III unarmed.

COXAE (Figs 25D, F; 27A, C, E, G, I): coxal plate I oval, with rounded anteroventral corner, armed with 9 setae; width/depth ratio is $0.74 / 1$; width/depth ratio of coxal plates II-IV are $1 / 1.1,1 / 1.14$ and $1 / 1.08$, respectively; anterior and ventral margins of coxal plates II-III with 11 setae each, anterior and ventral margins of coxal plates IV with 10 setae; with rounded anteroventral corners; coxal plates V-VI with large lobes anteriorly, posterior margins with 2 and 1 setae, respectively; anterior margins with 5 and 0 setae respectively; coxal plate VII trapezoid, with concave ventral margin; posterior lobe with 1 seta; coxal gills II-VI ovoid, length ratio of gills/bases of pereopods are $0.69 / 1,0.79$ / $1,0.85 / 1,0.84 / 1$ and $0.66 / 1$, respectively. 
Euxinian relict amphipods in the subterranean fauna of the Northern Black Sea region 299

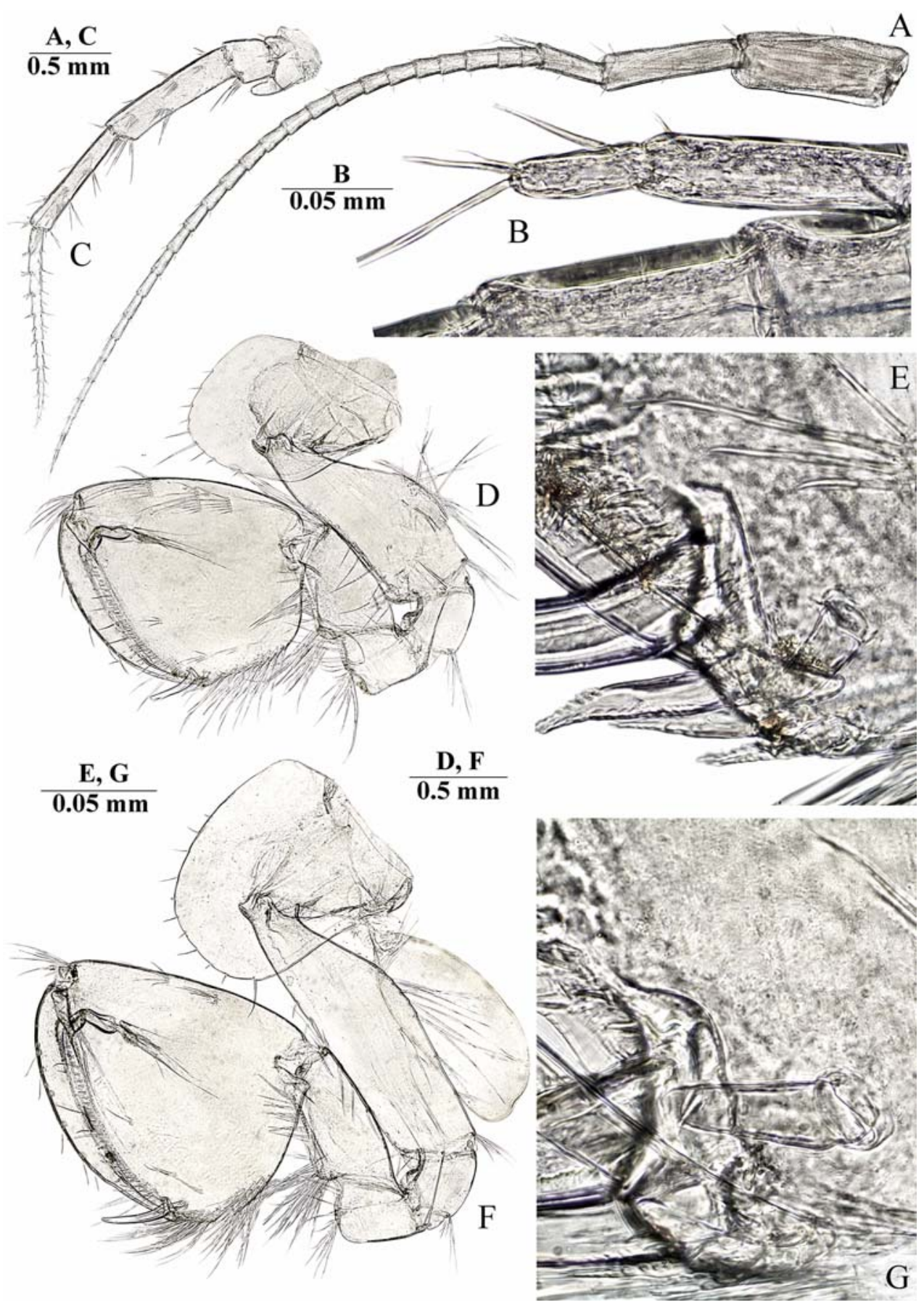

Fig. 25. Niphargus malakhovi sp.n., o: A — antenna I; B - accessory flagellum of antenna I; C — antenna II; D - gnathopod I; E - distoventral corner of chela of GnI; F - gnathopod II; G - distoventral corner of chela of GnII.

Fig. 25. Niphargus malakhovi sp.n., +: А — антенна I; В - дополнительный жгутик антенны I; C антенна II; D - гнатопод I; E - дистовентральный угол клешни GnI; F - гнатопод II; G дистовентральный угол клешни GnII. 


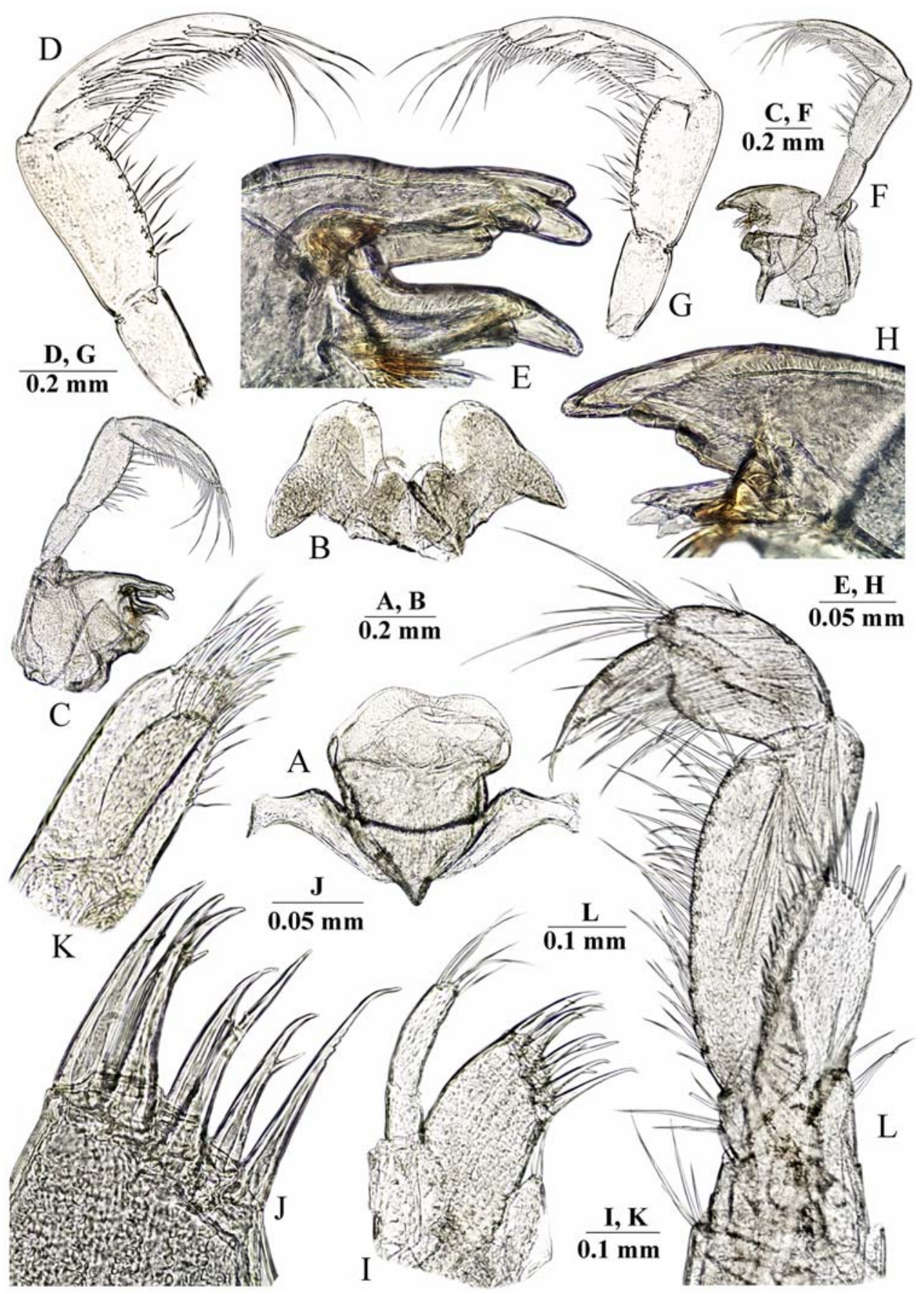

Fig. 26. Niphargus malakhovi sp.n., ㅇ: A - labrum (upper lip); B - labium (lower lip); C-D, F-G mandibles; E, H - incisor process and pars incisiva of mandible; I - maxilla I; J - same, distal margin of outer lobe; $\mathrm{K}$ - maxilla II; L - maxilliped.

Pис. 26. Niphargus malakhovi sp.n., +: А — верхняя губа; В - нижняя губа; C-D, F-G - мандибула; E, H - режущий отросток и pars incisiva (резец) мандибулы; I — максилла I; J — то же, дистальный край наружной доли; K — максилла II; L — максиллипед. 
Euxinian relict amphipods in the subterranean fauna of the Northern Black Sea region 301

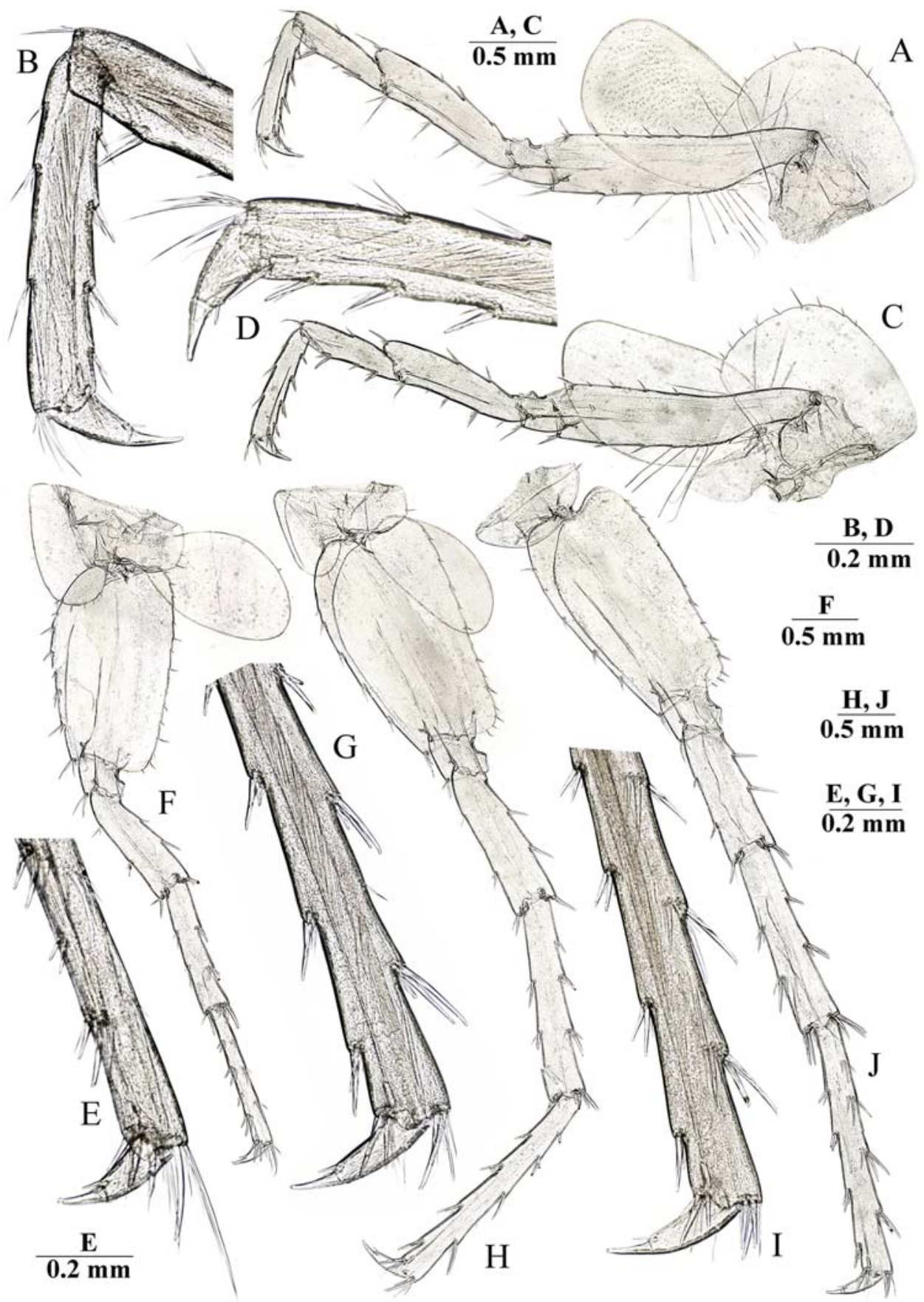

Fig. 27. Niphargus malakhovi sp.n., + : A - pereopod III; B — dactylus of PIII; C - pereopod IV; D dactylus of PIV; E - pereopod V; F - dactylus of PV; G - pereopod VI; H - dactylus of PVI; I pereopod VII; J - dactylus of PVII.

Fig. 27. Niphargus malakhovi sp.n., : А — переопод III. В - дактилус PIII; C - переопод IV; D дактилус PIV; E — переопод V; F — дактилус PV; G — переопод VI; H — дактилус PVI; I — переопод VII; J - дактилус VII. 


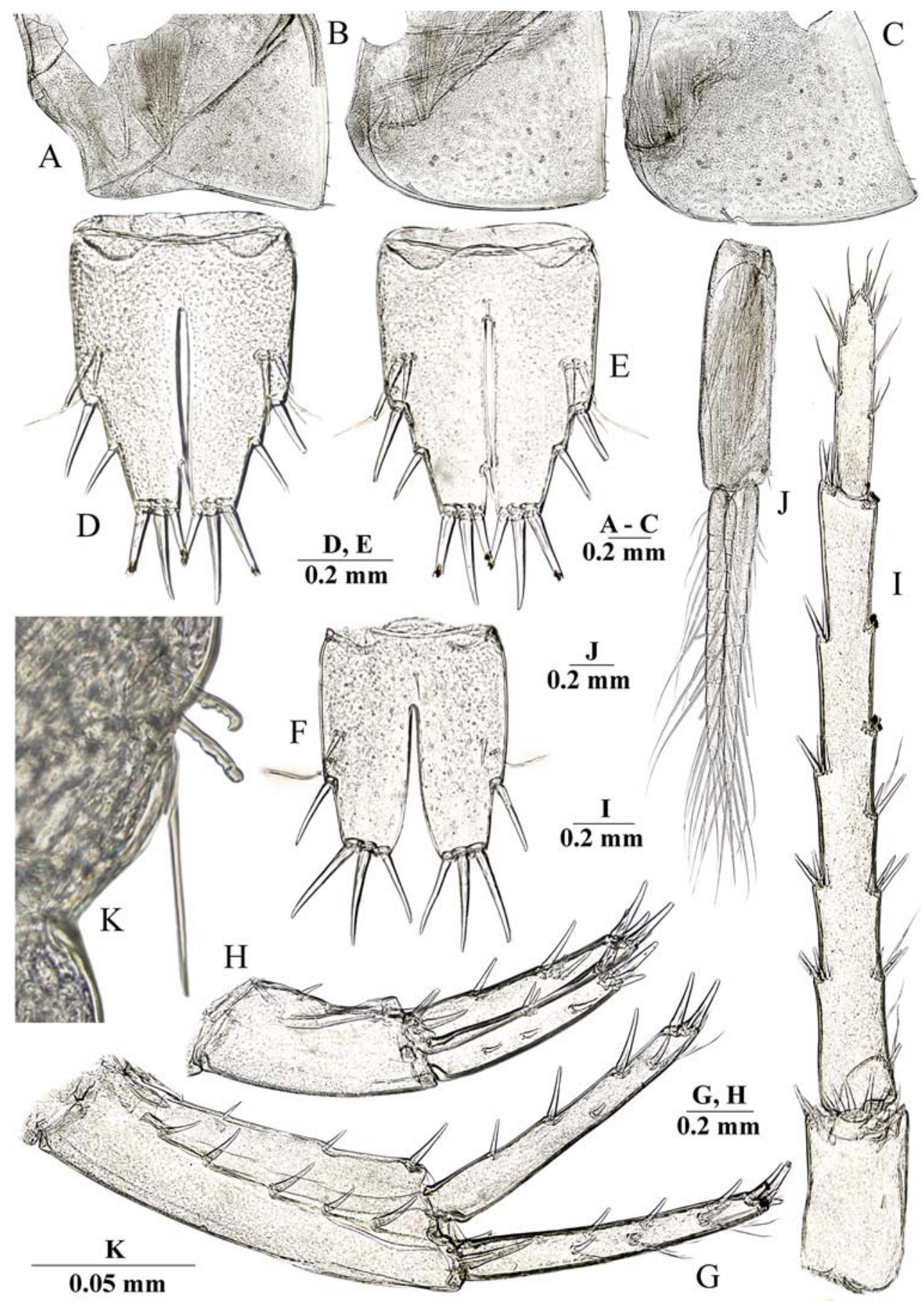

Fig. 28. Niphargus malakhovi sp.n.,, : A-C - epimeral plates I-III; D-F - telson (different specimens); $\mathrm{G}$ - uropod I; H - uropod II; I - uropod III; J - pleopod III; K — retinacula of pleopod III.

Fig. 28. Niphargus malakhovi sp.n., о: А-C - эпимеральные пластинки I-III; D-F - тельсон (различные экземпляры); G - уропод I; H - уропод II; I - уропод III; J — плеопод III; K ретинакула плеопод III. 
ANTENNA I (Fig. 25A): slender, about 0.6 of body length; peduncular articles moderately slender, ratio is $1 / 0.85 / 0.43$; flagellum with 27 articles, most of them with 2 short aesthetascs each; accessory flagellum short, 2-articulated (Fig. 25B); antennas I/II ratio is $1 / 0.62$.

ANTENNA II (Fig. 25C): peduncular articles moderately stout, with several long setae along ventral margin, dorsal setae shorter than inner ones; flagellum relatively short, consisting of 13 articles with relatively short setae; length of peduncle articles $4 / 5$ is $1 / 0.9$; flagellum is 0.73 times of length of peduncular articles $4+5$.

LABRUM (Fig. 26A): typical.

LABIUM (Fig. 26B): with entire, subrounded outer lobes and well developed smaller inner lobes.

MANDIBLE (Fig. 26C, F): left mandible: incisor process with 5 teeth, lacinia mobilis with 4 teeth; with row of 8 serrated setae between lacinia and molar process, few spatulate setae and one long seta at base of molar (Fig. 26E); mandibular palp articles $2 / 3$ (distal) ratio is 1/1.25-1.36; proximal article of palp without setae; article 2 with 16-19 setae; distal article with group of 7 A-setae; 3 groups of B-setae; 26 D-setae and 5-6 E-setae (Fig. 26D, G). Right mandible: incisor process with 4 teeth, lacinia mobilis 3-dentate, molar process triturative, with row of 8 serrated setae between lacinia and molar process (Fig. 26H).

MAXILLA I (Fig. 26I): inner lobe with 2 distal setae, outer lobe with 7 robust spines (6 spines with 1 strong lateral tooth each, inner spine with 4 small lateral teeth (1-1-1-1-1-14) (Fig. 26J); palp 2-articulated, distal article with 6 simple setae distally.

MAXILLA II (Fig. 26K): both plates with numerous long distal simple setae, outer lobe with row of fine setae along outer margin.

MAXILLIPED (Fig. 26L): inner plate short, with 4 distal robust setae intermixed with 7 distal simple setae; outer plate reaching half of palpal article 2 and bearing row of 19-20 distolateral spines and distal setae; palpal article 3 with 1 median and 1 distal bunches of seta at outer margin; palpal article 4 with 1 median seta at outer margin; nail shorter than pedestal, with 1 seta near basis.

GNATHOPOD I (Fig. 25D): basis elongated, with distal part greatly expanded; ischium with group of 7 posterodistal setae; merus subquadrate, equal to ischium; carpus is 0.49 of length of basis and 0.47 of length of propodus, with single distal group of setae anteriorly, with transverse rows of setae along posterior margin and row of setae posterolaterally; propodus subtrapezoidal, setose, with 8 rows of setae at posterior margin, anterior surface with 3 groups of total 6-8 setae each in addition to anterodistal group of 10-11 setae, several groups of short setae on inner surface, palmar corner armed with 1 long spiniform palmar seta, 3 serrated spiniform setae, single supporting spiniform seta on inner surface (Fig. 25E); dactylus with 7 setae along anterior margin, with row of short setae along inner surface; length of nail is 0.30 of total length of dactylus.

GNATHOPOD II (Fig. 25F): width/length ratio of basis is $0.30 / 1$, with 9 dorsolateral setae; ischium with 6 posterodistal setae; merus subquadrate, equal to ischium; carpus is 0.45 of length of basis and 0.55 of length of propodus, with distal group of setae anteriorly, few transverse rows of setae along posterior margin and row of setae posterolaterally; propodus subtrapezoidal, setose, larger than propodus of $\mathrm{GnI}$ (GnI/II as 0.9/1), posterior margin with 11 rows of setae, anterior surface with 2 group setae in addition to 7-8 anterodistal setae, with several groups of setae on inner surface, palmar corner with 2 strong palmar spiniform setae, single supporting spiniform seta on inner surface and 2 denticulated thick spiniform setae on outer side (Fig. 25G); dactylus with 6 setae along anterior surface and few short setae along inner surface; length of nail is about $0.26-0.30$ of total length of dactylus.

PEREOPODS III-IV (Fig. 27A, C): almost similar in size and shape; basis is $4.56-4.60$ times as long as wide, with posterior margin bearing long marginal setae, with distoventral group of setae; ischium short, subquadrate, with distoventral group of setae; merus with slender simple setae along anterior and posterior surfac- 
es; carpus/propodus ratio is $0.90-0.91$; propodus with 4 groups of spines along ventral margin; dactylus (Fig. 27B, D) relatively stout, curved, sharp distally, with 1 small additional posterior median spine and 1 median short plumose seta at outer margin; dactyli ratio of PpIII/ IV is $1 / 1.12$; length of nail is $0.43-0.44$ of total length of dactylus.

PEREOPODS V-VII(Fig. 27E, G, I): length ratio of $\mathrm{PpV} / \mathrm{VI} / \mathrm{VII}$ is $1 / 1.35 / 1.36$; length of PVII is about half of total body length.

PEREOPOD V (Fig. 27E): length/width ratio of basis is $1 / 0.61$, almost rectangular, with explicit posteroventral lobe; with facial setae; posterior margin almost straight, with row of 16 slender marginal setae; anterior margin convex, with row of 6 slender marginal setae, which are distinctly longer than posterior ones, and group of setae in distal part; ischium subquadrate; merus with 2 bunches of slender spines along anterior surface and with 2 spines on posterior surface; propodus slender, 8.6 times as long as wide, with several bunches of short spines; dactylus (Fig. 29F) with 1 small additional posterior median spine and 1 median short plumose seta at outer margin.

PEREOPOD VI (Fig. 27G): length/width ratio of basis is $1 / 0.55$, with facial setae, posteroventral lobe and almost straight posterior margin bearing row of 17 short marginal setae, anterior margin convex, with row of 5 longer marginal setae; merus with several bunches of short spines along anterior and posterior surfaces; carpus with group of spines intermixed with single short setae; propodus slender, about 8.9 times as long as wide, with several group of short spines; dactylus (Fig. 27H) slender, with 1 small additional posterior median spine and 1 short median plumose seta at outer margin.

PEREOPOD VII (Fig. 27I): length/width ratio of basis is $1 / 0.54$, with distinct posteroventral lobe and almost straight posterior margin bearing row of 14 short marginal setae; with facial setae; anterior margin convex, with row of 5 longer marginal setae; carpus with 2 groups of spines along anterior and posterior surfaces; propodus slender, about 8.5 times as long as wide, with several groups of short spines; dac- tylus (Fig. 27J) with 1 median spine and 1 seta at inner margin, and 1 short median plumose seta at outer margin.

PLEOPODS (Fig. 28J): pleopod I with basal segment armed with 1-2 simple setae and 2 coupling hooks in retinacula; pleopod II with basal segments smooth, with 2 coupling hooks in retinacula; pleopod III with basal segment armed with 2-3 small and medium-sized simple setae and 2 coupling hooks accompanied by 1 large simple seta in retinacula (Fig. 28K).

UROPOD I (Fig. 28G): protopodite longer than rami, 3.4 times as long as wide, with dorsointernal row of 2 median setae and one subdistal spine, and with dorsoexternal row of 5 spines; rami straight and subequal in length, endopodite not paddle-like, with 3 dorsolateral and 2 mesial spines one of which accompanying by several (2-3) simple setae, 4 apical spines; exopodite with 3 mesial groups consisting of single spines accompanying by several (2-4) simple setae and 3 spines dorsolaterally; 4 apical spines.

UROPOD II (Fig. 28H): protopodite 2.3 times as long as wide, subequal rami; rami with lateral, mesial and distal slender spines, endopodite with 2 spines dorsolaterally, 1-2 spines mesially, 5 spines apically; exopodite with 2 spines dorsolaterally and 3 spines mesially, 5 spines apically; length ratio of exopodite/endopodite is $1 / 1.14$.

UROPOD III (Fig. 28I): about 0.37 of body length in females; Female: protopodite 1.84 times as long as wide, with 1 lateral seta and 89 apical spiniform setae; rami unequal, endopodite short, about 9.8 times shorter than exopodite, without lateral setae, with 3 setae subapically, including 1 spiniform and 1 long plumose seta; distal article is 0.33 of length of proximal article, with 2-3 groups of thin-flexible setae along each margin and group of simple setae apically; proximal article with 4 groups of spiniform setae along outer margin and 5 groups of thin-flexible, plumose and spiniform setae along inner margin.

TELSON (Fig. 28D-F): length/width ratio is $1 / 0.81$; cleft is 0.73 of length of telson; margins straight, narrowing apically; with variable armature, including 3 medium distal spines on 
each lobe, 2 lateral spines, accompanied by 2 plumose setae on each outer margins, $0-1$ spine on inner margins on each side, 2 sublateral spines (on each side) and 1 small mesial seta on dorsal surface; apical spiniform setae are 0.33 of length of telson.

COLORATION. Body, appendages and internal organs are whitish or yellowish characteristic of stygobiotic representatives of the genus.

BODY SIZE. The largest collected ${ }^{\circ}$ has tbl. $8.5 \mathrm{~mm}$.

GENBANK (NCBI) ACCESSION NUMBERS. MZ382408, MZ382409.

TAXONOMIC REMARKS. Niphargus malakhovi sp.n. can be separated from these and related species of the "tauricus" ingroup (Table 1) by 1) a relatively long antenna II with 27 articles; 2) an elongated coxal plate III with width/depth ratio is about $1.14 / 1 ; 3$ ) article 2 of mandible palp with 16-19 setae (vs. about 1014 setae in other species); and 4) a relatively short protopodite of uropod I with length/width ratio is about 3.4 (vs. 4-5 in other species).

ETYMOLOGY. The species is named after Academician Dr. Sci. Vladimir Vasilyevich Malakhov, who has been the Head of the Invertebrate Zoology Department at the M.V. Lomonosov Moscow State University (Moscow) for many years.

ECOLOGY AND DISTRIBUTION. Niphargus malakhovi sp.n. was presently found exclusively in the Natashka Spring (4431. $449^{\prime} \mathrm{N}, 38^{\circ} 17.650^{\prime} \mathrm{E}$ ), about $158 \mathrm{~m}$. a.s.l., located in the Doguab River basin, living in hyporhea and the base of thespring, in the depth of bottom sediments consisting of fallen leaves and vegetation remnants. An additional material (see above) we got from small springs in the valleys and hyporhea of small neighbouring rivers (Hotecay, Dzhankhot and Azmashakh), flowing in the valleys between neighbouring mountains (Mikhailovskaya, Dimegina, Idokopas and Tkhachehochuk) adjacent to the Black Sea coast, in the springs along the southern slope of the Doguab riverbed (a tributary of the Pshada River), the lower part of the Pshada River and the small coastal Betta River; at the same time the rather large genetic split between the speci- mens sampled from these localities (see subclade D on Fig. 1) will probably allow to describe some cryptic species from the area. According to the results of the isotope analysis, the species from these habitats are herbivorous (see Marin et al., 2021 as Niphargus cf. tauricus); in many sampling localities, they compete with representatives of the genus Gammarus, which most likely displaces them ecologically, and, possibly, feeding on them. In the area of the Bzhid and Pshada rivers, these species are probably representing food resource for another predatory niphargids species from the "puteanus" group, Niphargus bzhidik Marin, Krylenko et Palatov, 2021, which lives in epigean and subterranean habitats of the same small rivers in this area (Marin et al., 2021).

\section{Niphargus dederkoyi Marin et Palatov sp.n.} Figs 29-32; 33F.

MATERIAL EXAMINED. HOLOTYPE, + (bl. $8.5 \mathrm{~mm}$ ) (ZMMU Mb-1196), RUSSIA, Krasnodar Krai, SE slope of the Great Caucasian Ridge, Tuapse district, $44^{\circ} 04.007^{\prime} \mathrm{N}, 39^{\circ} 08$. $380^{\prime} \mathrm{E}$, about $110 \mathrm{~m}$ a.s.1., a small spring in the riverbed of the Dederkoyi River, hand net sampling, coll. I. Marin \& D. Palatov, 13.05.2019. PARATYPES, 7우 (bl. 3.0-6.0 mm) (ZMMU Mb-1197), same locality and date as holotype, coll. D. Palatov, 19.07.2020.

ADDITIONAL MATERIAL. RUSSIA, Krasnodar Krai, SE slope of the Great Caucasian Ridge, Tuapse district: 390, Kazachya Schel, N of Tyumenskiy, $44^{\circ} 11.405^{\prime} \mathrm{N}, 38^{\circ}$ $58.467^{\prime} \mathrm{E}$, about $72 \mathrm{~m}$ a.s.l., a seepage in the riverbed, hand net sampling, coll. I. Marin \& D. Palatov, 12.05.2019; 3 우, $\mathrm{N}$ of Shepsi, $44^{\circ} 03$. $373^{\prime} \mathrm{N}, 39^{\circ} 11.050^{\prime} \mathrm{E}$, about $117 \mathrm{~m}$ a.s.l., a seepage in the riverbed of the left tributary of the Shepsi river, hand net sampling, coll. I. Marin \& D. Palatov, 13.05.2019.

DESCRIPTION.

BODY: depigmented, moderately slender.

HEAD: length is approximately $10 \%$ of body length; rostrum and pigmented spots on anterior lobe absent, with subrounded lateral cephalic lobes and excavated anteroventral sinus. 


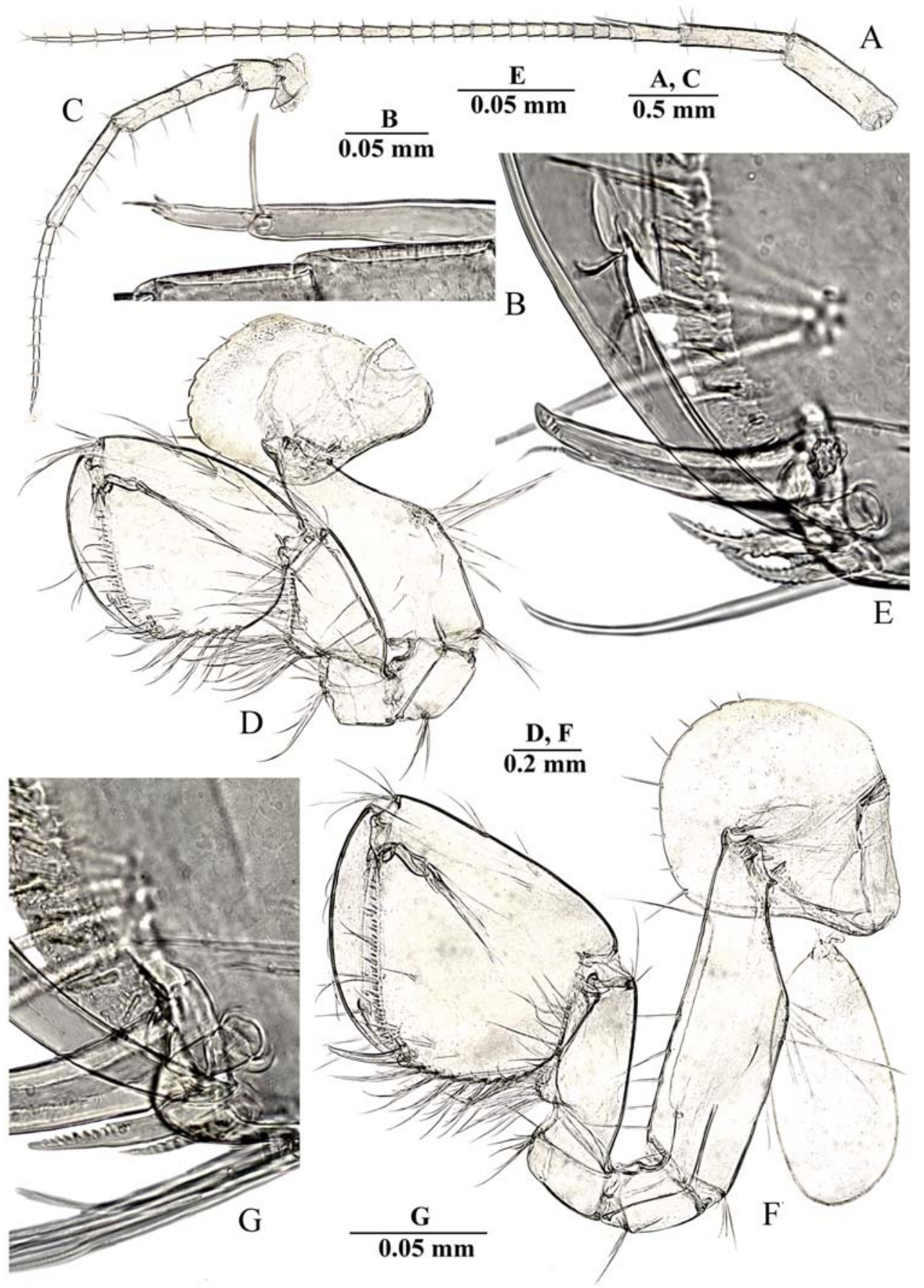

Fig. 29. Niphargus dederkoyi sp.n., o : A — antenna I; B — accessory flagellum of antenna I; C — antenna II; D - gnathopod I; E - distoventral corner of chela of GnI; F — gnathopod II; G - distoventral corner of chela of GnII.

Fig. 29. Niphargus dederkoyi sp.n., о: А — антенна I; В — дополнительный жгутик антенны I; C антенна II; D - гнатопод I; E — дистовентральный угол клешни GnI; F — гнатопод II; G дистовентральный угол клешни GnII. 


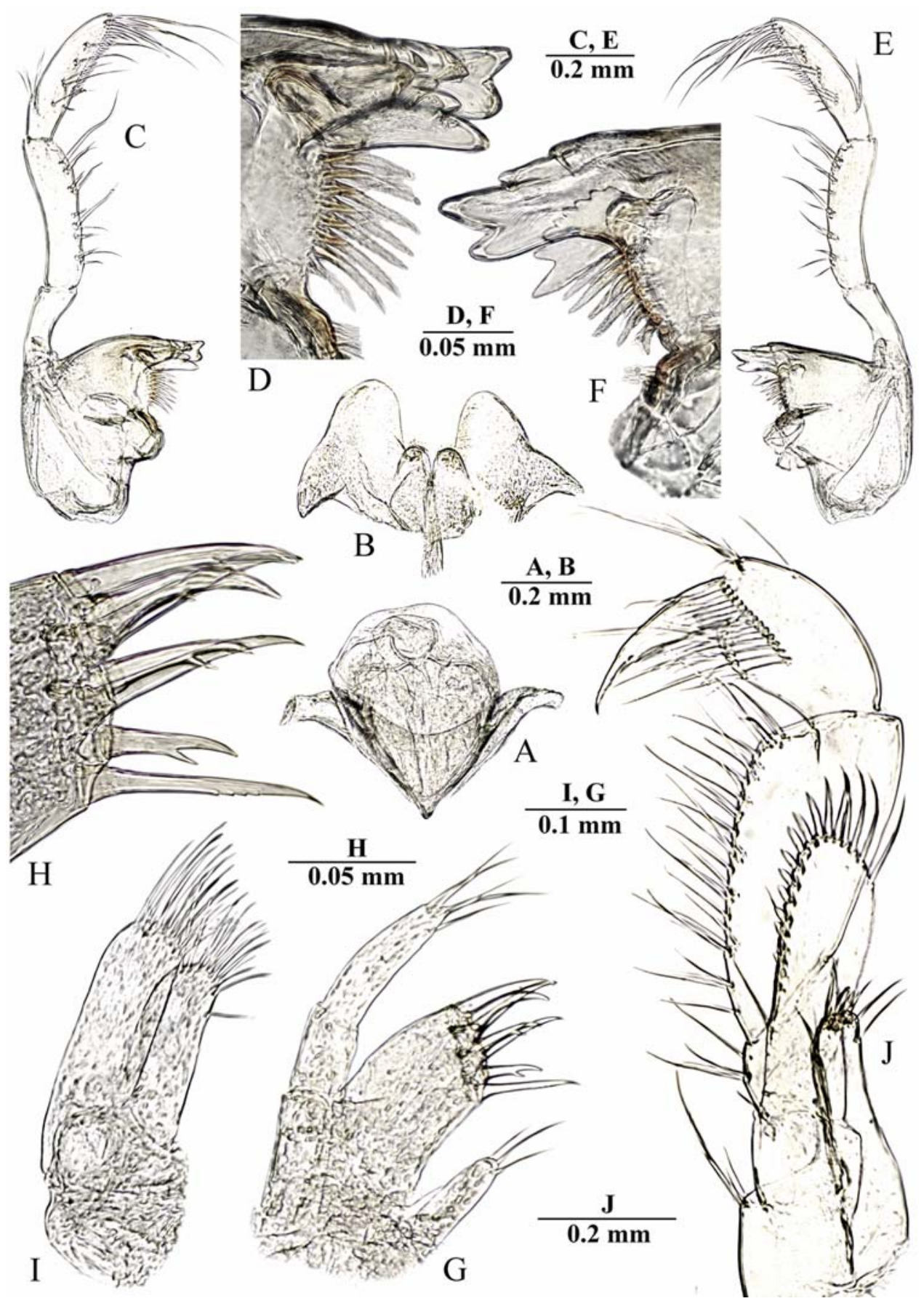

Fig. 30. Niphargus dederkoyi sp.n., o: A — labrum (upper lip); B — labium (lower lip); C, E — mandibles; $\mathrm{D}, \mathrm{F}$ - incisor process and pars incisiva of mandibles; $\mathrm{G}$ - maxilla I; H - same, distal margin of outer lobe; I - maxilla II; J - maxilliped.

Pис. 30. Niphargus dederkoyi sp.n., + : А — верхняя губа; В - нижняя губа; C-E - мандибула; D, F режущий отросток и pars incisiva (резец) мандибулы; $\mathrm{G}$ - максилла I; H - то же, дистальный край наружной доли; I — максилла II; J — максиллипед. 


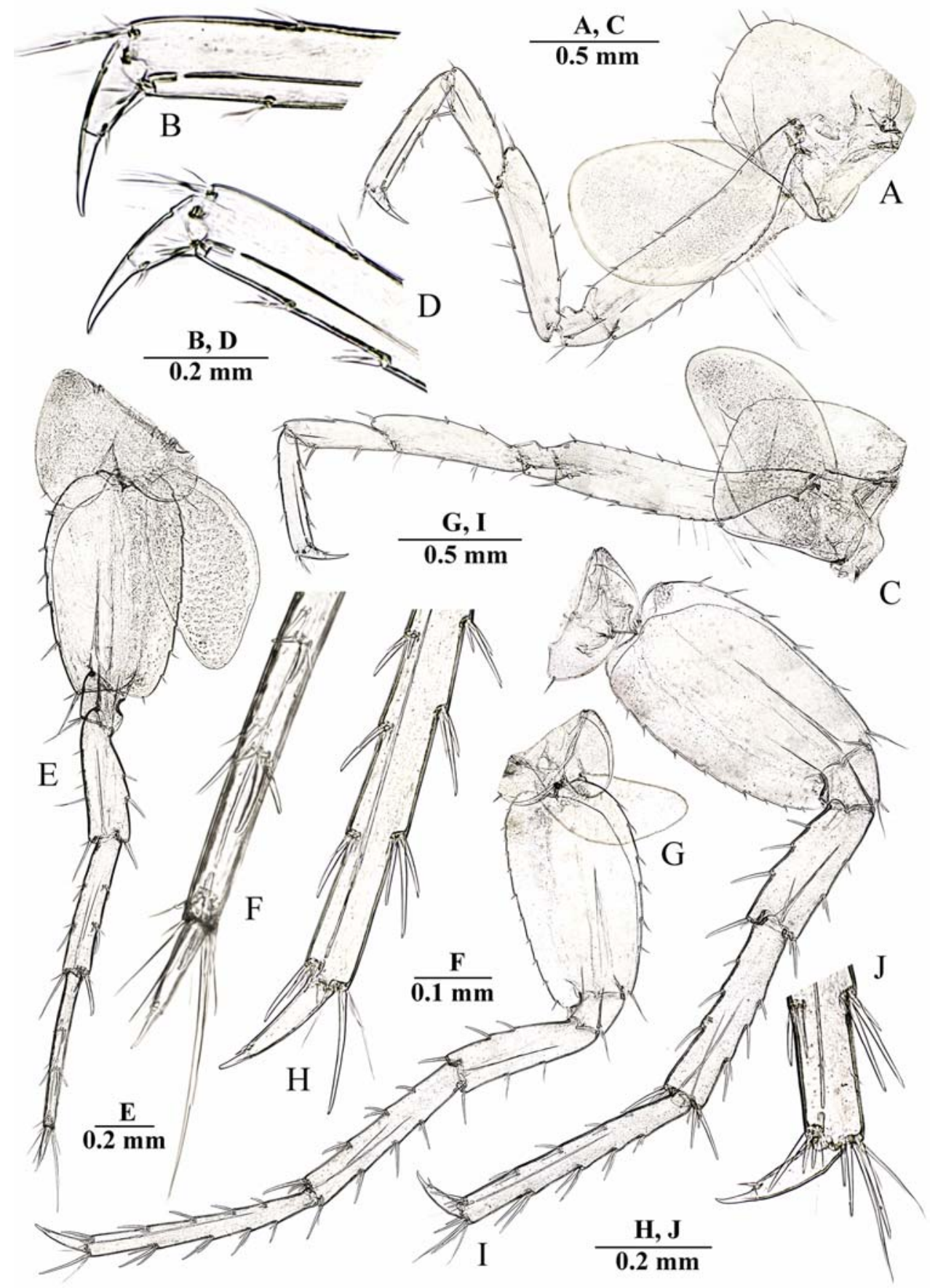

Fig. 31. Niphargus dederkoyi sp.n.,, : A - pereopod III; B — dactylus of PIII; C - pereopod IV; D dactylus of PIV; E - pereopod V; F - dactylus of PV; G - pereopod VI; H - dactylus of PVI; I pereopod VII; J - dactylus of PVII.

Fig. 31. Niphargus dederkoyi sp.n.,, : A — переопод III. В - дактилус PIII; C - переопод IV; D дактилус PIV; E — переопод V; F — дактилус PV; G — переопод VI; H — дактилус PVI; I — переопод VII; J - дактилус VII. 
Euxinian relict amphipods in the subterranean fauna of the Northern Black Sea region 309

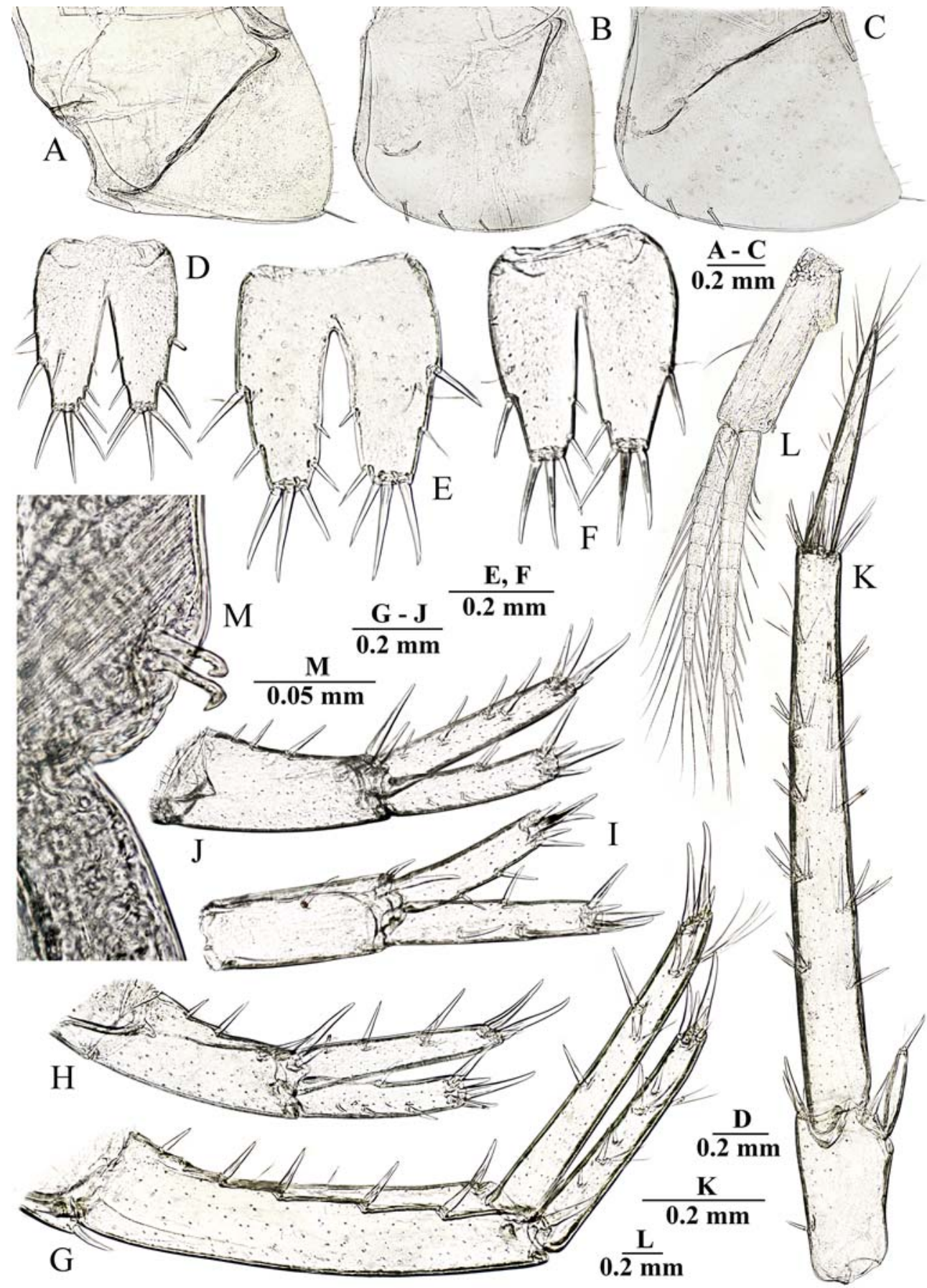

Fig. 32. Niphargus dederkoyi sp.n.,, : A-C - epimeral plates I-III; D-F - telson (different animals); G uropod I; F-J - uropod II; K - uropods II; L — pleopod III; M - retinacula of pleopod III.

Рис. 32. Niphargus dederkoyi sp.n., +: А-C - эпимеральные пластинки I-III; D-F - тельсон (различные экземпляры); G - уропод I; F-J - уропод II; K - уропод II; L — плеопод III; M ретинакула плеопод III. 


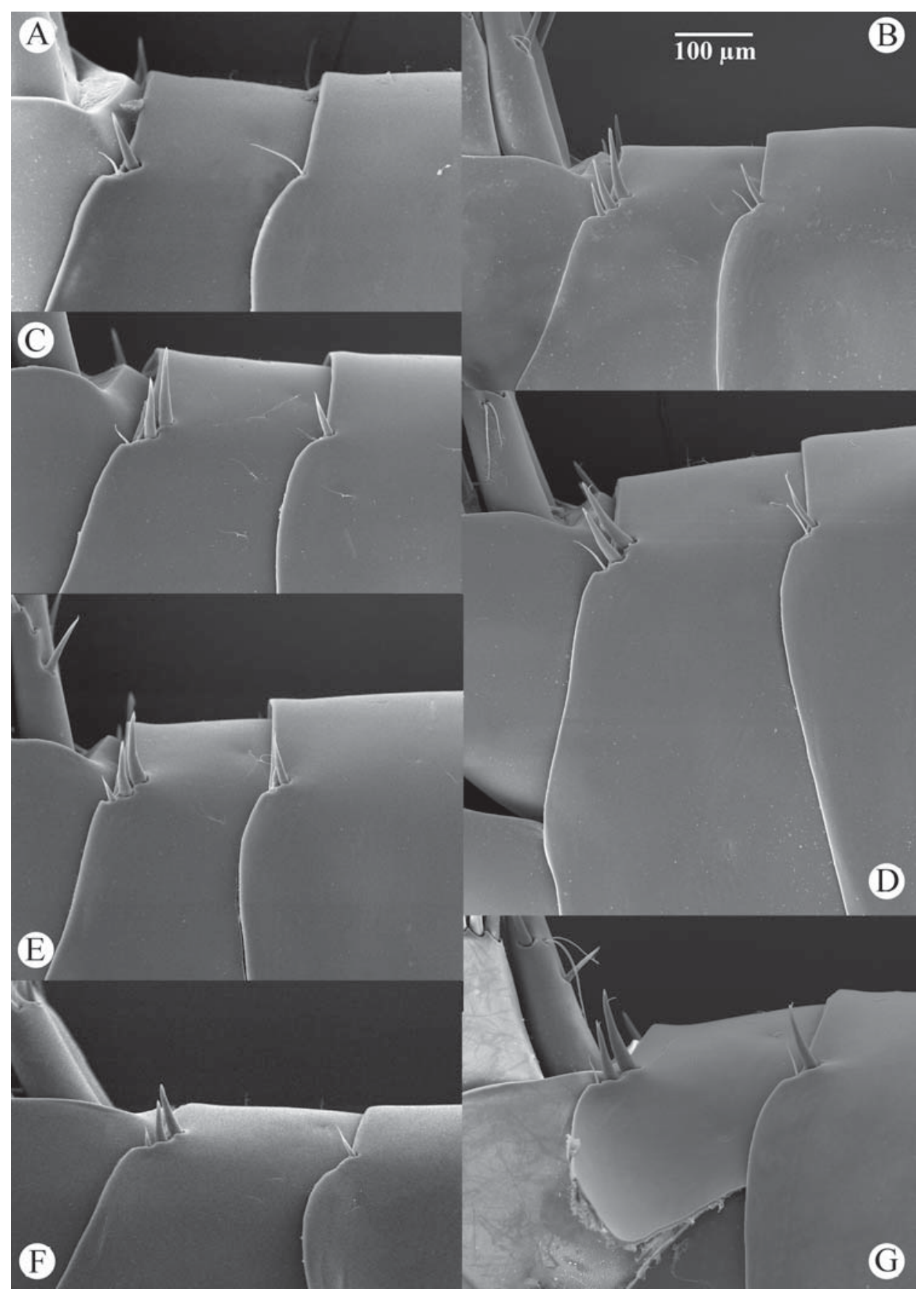

Fig. 33. Urosomal segments of the species from the Niphargus "tauricus" ingroup: A $-N$. tauricus Birštein, 1964; B - N. utrishensis sp.n.; C $-N$. novorossicus sp.n.; D $-N$. ashamba sp.n.; E - N. alisae sp.n.; F N. dederkoyi sp.n.; G - N. malakhovi sp.n.

Рис. 33. Уросомальные сегменты видов из ингруппы Niphargus "tauricus": А - N. tauricus Birštein, 1964; B - N. utrishensis sp.n.; C - N. novorossicus sp.n.; D - N. ashamba sp.n.; E — N. alisae sp.n.; F - N. dederkoyi sp.n.; G $-N$. malakhovi sp.n. 
PEREON: pereonites I-VII without setae, smooth.

PLEOSOMA: pleonites I-III with several short marginal setae on each posterodorsal margin.

EPIMERAL PLATES: posteroventral corners of epimeral plates I-II nearly right-angled, slightly rounded; posteroventral corners of epimeral plates III bluntly pointed shaped (Fig. $32 \mathrm{~A}-\mathrm{C})$. Epimeral plate I: posterior margin convex, ventral margin slightly convex; without spines along ventral margin; with 7 setae along posterior margin; posteroventral angle with 1 strong seta. Epimeral plate II: posterior and ventral margins slightly convex, with 3 spiniform setae on ventral margin; 9 setae along posterior margin; posteroventral angle with 1 strong seta. Epimeral plate III: posterior margin oblique, concave, ventral margin slightly convex; with 3 spiniform setae along ventral margin; with 7 setae along posterior margin; posteroventral angle with 1 strong seta.

UROSOMITES (Fig. 33F): urosomite I with 1 slender spine on each side dorsolaterally, with 1 posteroventral spines near basis of uropod I dorsolaterally; urosomite II with 3 simple strong spines on each side dorsolaterally; urosomite III unarmed.

COXAE (Figs 29D, F; 31A, C, E, G, I): coxal plate I oval, with rounded anteroventral corner, armed with 10 setae; width/depth ratio is 0.82 ; width/depth ratio of coxal plates II-IV are $1 / 0.96,1 / 1.13$ and $1 / 1.07$, respectively; anterior and ventral margins of coxal plates II-IV with 9, 7 and 8 setae, respectively; with rounded anteroventral corners. Coxal plates V-VI with large lobes anteriorly, posterior margins with 2 setae each; anterior margins with 4 and 1 setae, respectively. Coxal plate VII trapezoid, with concave ventral margin; posterior lobe with 1 seta. Coxal gills II-VI ovoid, length ratio of gills/bases of pereopods are $0.74 / 1,0.8 / 1,0.9 / 1$, 0.93/1 and 0.67/1, respectively.

ANTENNA I (Fig. 29A): slender, about 0.58 of body length; peduncular articles moderately slender, ratio is $1 / 0.86 / 0.39$; flagellum with 27 articles, most of them with 2 short aesthetascs each; accessory flagellum short, 2- articulated (Fig. 29B); antennas I/II ratio is 1/ 0.76 .

ANTENNA II (Fig. 29C): peduncular articles moderately stout, with several long setae along ventral margin, dorsal setae shorter than inner ones; flagellum relatively short, consisting of 12 articles with relatively short setae; length of peduncle articles $4 / 5$ is $1 / 0.9$; flagellum is 0.72 times of length of peduncular articles $4+5$.

LABRUM (upper lip) (Fig. 30A): typical.

LABIUM (lower lip) (Fig. 30B): with entire, subrounded outer lobes and well developed smaller inner lobes.

MANDIBLE (Fig. 30C, E): left mandible: incisor process with 5 teeth, lacinia mobilis with 4 teeth; with row of 8 serrated setae between lacinia and molar process, few spatulate setae and one long seta at base of molar (Fig. 30D); mandibular palp article 2-3 (distal) subequal in length; proximal article of palp without setae; article 2 with 12 setae; distal article with group of 6-7 A-setae; 3 groups of B-setae; 25 Dsetae and 5-6 E-setae. Right mandible: incisor process armed with 4 teeth, lacinia mobilis bifurcate, molar process triturative, with row of 7 serrated setae between lacinia and molar process (Fig. 30F).

MAXILLA I (Fig. 30G): inner lobe with 3 distal setae, outer lobe with 7 robust spines (6 spines with 1 strong lateral tooth each, inner spine with 4 small lateral teeth (1-1-1-1-1-14) (Fig. 30H); palp 2-articulated, distal article with 5 simple setae distally.

MAXILLA II (Fig. 30I): both plates with numerous long distal simple setae, outer lobe with row of fine setae along outer margin.

MAXILLIPED (Fig. 30J): inner plate short, with 3-4 distal robust setae intermixed with 57 distal simple setae; outer plate reaching half of palpal article 2 and bearing row of 18-19 distolateral spines and distal setae; palpal article 3 with 1 median and 1 distal bunches of setae at outer margin; palpal article 4 with 1 median seta at outer margin; nail shorter than pedestal, with 1 seta near basis.

GNATHOPOD I (Fig. 29D): basis elongated, with distal part greatly expanded; ischium 
with group of 4 posterodistal setae; merus subquadrate, equal to ischium; carpus is 0.52 of length of basis and 0.62 of length of propodus, with single distal group of setae anteriorly, with transverse rows of setae along posterior margin and row of setae posterolaterally; propodus subtrapezoidal, setose, with 5 rows of setae at posterior margin, anterior surface with 2 groups of 4-5 setae each in addition to anterodistal group of 6-7 setae, several groups of short setae on inner surface, palmar corner armed with 1 long spiniform palmar seta, 2 serrated spiniform setae, single supporting spiniform seta on inner surface (Fig. 29E); dactylus with 5 setae along anterior margin, with row of short setae along inner surface; length of nail is $0.29-0.30$ of total length of dactylus.

GNATHOPOD II (Fig. 29F): width/length ratio of basis is $0.3 / 1$, with 6 dorsolateral setae; ischium with 3 posterodistal setae; merus subquadrate, equal to ischium; carpus is about 0.5 of length of basis and 0.6 of length of propodus, with distal group of setae anteriorly, few transverse rows of setae along posterior margin and row of setae posterolaterally; propodus subtrapezoidal, setose, larger than propodus of $\mathrm{GnI}$ $(\mathrm{GnI} / \mathrm{II}$ as $0.8 / 1)$, posterior margin with 8 rows of setae, anterior surface with 2 group setae in addition to 8-9 anterodistal setae, with several groups of setae on inner surface, palmar corner with 1 strong palmar spiniform seta, single supporting spiniform seta on inner surface and 2 denticulated thick spiniform setae on outer side (Fig. 29G); dactylus with 5 setae along anterior surface and few short setae along inner surface; length of nail is about $0.26-0.26$ of total length of dactylus.

PEREOPODS III-IV (Fig. 31 A, C): almost similar in size and shape; basis is 4.6-4.91 times as long as wide, with posterior margin bearing long marginal setae, with distoventral group of setae; ischium short, subquadrate, with distoventral group of setae; merus with slender simple setae along anterior and posterior surfaces; carpus/propodus ratio is $0.82-0.86$; propodus with 3 groups of spines along ventral margin; dactylus (Fig. 31B, D) relatively stout, curved, sharp distally, with 1 small additional posterior medi- an spine and 1 median short plumose seta at outer margin; dactyli ratio of PpIII/IV is $1 / 0.97$; length of nail is $0.48-0.49$ of total length of dactylus.

PEREOPODS V-VII(Fig. 31E, G, I): length ratio of $\mathrm{PpVI} / \mathrm{VII}$ is $1 / 1.03$; length of $\mathrm{PVII}$ is about half of total body length.

PEREOPOD V (Fig. 31E): length/width ratio of basis is $1 / 0.61$, almost rectangular, with explicit posteroventral lobe; with facial setae; posterior margin almost straight, with row of 16 slender marginal setae; anterior margin convex, with row of 6 slender marginal setae, which are distinctly longer than posterior ones, and group of setae in distal part; ischium subquadrate; merus with 2 bunches of slender spines along anterior surface and with 2 spines on posterior surface; propodus slender, 8.6 times as long as wide, with several bunches of short spines; dactylus (Fig. 31F) with 1 small additional posterior median spine and 1 median short plumose seta at outer margin.

PEREOPOD VI (Fig. 31G): length/width ratio of basis is $1 / 0.69$, with facial setae, feebly marked posteroventral lobe and slightly convex posterior margin bearing row of 14 short marginal setae, anterior margin convex, with row of 6 longer marginal setae; merus with several bunches of short spines along anterior and posterior surfaces; carpus with group of spines intermixed with single short setae; propodus slender, about 9.3 times as long as wide, with several group of short spines; dactylus (Fig. $31 \mathrm{H})$ slender, with 1 small additional posterior median spine and 1 short median plumose seta at outer margin.

PEREOPODS VII (Fig. 31I): length/width ratio of basis is $1 / 0.61$, with facial setae, feebly marked posteroventral lobe and slightly convex posterior margin bearing row of 11 short marginal setae; anterior margin convex, with row of 5 longer marginal setae; carpus with 3 groups of spines along anterior and posterior surfaces; propodus slender, about 7.6 times as long as wide, with several groups of short spines; dactylus (Fig. 31J) with 1 median spine and 1 seta at inner margin, and 1 short median plumose seta at outer margin. 
PLEOPODS (Fig. 32L): pleopod I with basal segment armed with 2 small simple setae and 2 coupling hooks in retinacula; pleopod II basal segment armed with 1 small simple seta and 2 coupling hooks in retinacula; pleopod III with basal segment armed with 2-3 medium-sized simple setae, 1 large plumose seta and 2 coupling hooks in retinacula (Fig. 32M).

UROPOD I (Fig. 32G): protopodite longer than rami, 5 times as long as wide; with dorsointernal row of 2 median setae and one subdistal spine, and with dorsoexternal row of 5 spines; rami straight, exopodite/endopodite ratio is $1 /$ 1.33; endopodite not paddle-like, with 2 dorsolateral spines and 2 mesial groups include of 2 slender spines accompanying by several (2-4) simple setae, 4 apical spines; exopodite with 2 mesial groups consisting of single spines accompanying by several (2-3) simple setae and 3 mesial simple spines; with 5 apical spines.

UROPOD II (Fig. 32H-J): protopodite 2.7 times as long as wide; rami with lateral, mesial and distal slender spines: endopodite with 3 long spines dorsolaterally, 4 spines apically; exopodite with 1 spine dorsolaterally and 3 spines mesially, 4 spines apically; exopodite/ endopodite ratio is $1 / 1.3$.

UROPOD III (Fig. 32K): about 0.4 of body length in females; protopodite 1.85 times as long as wide, with 1 lateral spiniform seta and 6 apical spiniform setae; rami unequal, endopodite short, about 9.0 times shorter than exopodite, without lateral setae, with 2 setae subapically, including 1 spiniform seta; distal article is 0.4 of length of proximal article, with 4 groups of thinflexible setae along each margin and group of simple setae apically; proximal article with 5 groups of spiniform and thin-flexible setae along outer margin and 5 groups of thin-flexible, plumose and spiniform setae along inner margin.

TELSON (Fig. 32D-F): length/width ratio is $1 / 0.92$; cleft is 0.70 of length of telson; margins straight, narrowing apically; with variable armature, including 3 medium distal spines on each lobe, 2 lateral spines, accompanied by 2 plumose setae on each outer margins, 2 spines on inner margins on each side, without sublateral spines and 1 small mesial seta on dorsal surface; apical spiniform setae are 0.44 of length of telson.

COLORATION. Body, appendages and internal organs are whitish or yellowish characteristic of stygobiotic representatives of the genus.

BODY SIZE. The largest collected $q$ has tbl. $8.5 \mathrm{~mm}$.

GENBANK (NCBI) ACCESSION NUMBERS. MZ382323-MZ382326.

TAXONOMIC REMARKS. Niphargus dederkoyi sp.n. can be separated from related species of the "tauricus" ingroup (see Table 1) by 1) unequal rami of uropod I with exopodite/ endopodite ratio is about $1 / 1.33$ (vs. almost equal in other species of the group); 2) high and short coxal plate III with width/depth ratio is about $1 / 1.13$; 3); 3) a relatively long protopodite of uropod I with length/width ratio is about 5.9 (vs. 3.4-4.4 in other species); 4) a relatively long antenna II with 27 articles; and 5) a relatively long distal segment of exopod of uropod III.

ETYMOLOGY. The species is named after the Dederkoy River, where it was firstly discovered.

ECOLOGY AND DISTRIBUTION. Niphargus dederkoyi sp.n. inhabits springs and hyporhea of several small neighbouring rivers flowing into the Black Sea from the northwestern slope of the Greater Caucasus Ridge in the area of Tuapse - small unnamed river near the Tyumensky village (Kazachya Shel), Dederkoyi and Shepsi rivers. Some of specimens were found under large boulders or sunken fallen leaves, showing that they can survive for some time outside their subterranean habitats.

THE IDENTIFICATION KEY FOR THE SPECIES OF THE NIPHARGUS "TAURICUS" INGROUP (“STYGIUS" GROUP)*

1. Rami of uropod I are distinctly different in length; armature of pleopod III includes large pubescens bristle; telson without dorsal spines or with single small spike on one of lobes N. dederkoyi sp.n.

- Rami of uropod I are equal in length; armature of pleopod III includes only simple small-sized

* Morphological comparison of all species of the "tauricus" ingroup is also presented in Supplement. 
bristles; telson with dorsal spines on both lobes 2

2. Antenna I is relatively short in $\sigma^{\top} \sigma^{7}$, less than $21-$ 23 articles.... 3

- Antenna I is relatively large in $\sigma^{\top} \sigma^{7}$, with more than 26-32 articles... .. 5

3. The distal segment uropod III is relatively long in $+\circ$, at least half the length of the proximal segment; the height of coxal plate II is distinctly larger than its width ....

N. tauricus Birštein, 1964

- The distal segment uropod III is relatively short in $+\rightarrow$, about $1 / 3$ of the length of the proximal segment; the height of coxal plate II is approximately equal to the width

4. Propodus of pereopod V is about 6 times, while pereopod VII is about 10 times as long as wide; uropod III with exopodite about 13 times longer than endopodite, its distal segment is shorter than the proximal one in $\sigma^{7} \sigma^{7}$; telson with its length exceeding its width for about 1.3 times N. utrishensis sp.n.

- Propodus of pereopod V is about 7-8 times, while pereopod VII is about 11 times as long as wide; uropod III with exopodite about 15 times longer than endopodite, its distal segment is distinctly longer than the proximal in $\sigma^{7} \sigma^{7}$; telson with its length exceeding the width for about 1.15 times ..N. alisae sp.n.

5. Coxal gill VI is very short, no more than 0.42 of the length of basipodite of pereopod VI; antenna AI with 32 articles in males; palmar margin of GnII is armed with 1 long spiniform seta and 1 smaller serrated seta.

.. N. dancaui Brad, Fišer, Flot et Sarbu, 2015

- Coxal gill VI is relatively large, up to $0.58-0.70$ of the length of basipodite of pereopod VI; antenna AI with 28 articles in male; palmar margin of GnII is armed with 1 long spiniform seta and 2 serrated setae

.. 6

6. The length of coxal plates II-III significantly exceeds its width ................. malakhovi sp.n.

- The length of coxal plates II-III is equal or slightly shorter than its width 7

7. Basipodite of pereopod VII is distinctly convex along the posterior margin in $\sigma^{7} \sigma^{\top}$; propodus VI is about 9 times longer than its width; propodus of PV is about 7-7.4 times longer than its width; coxal gill $\mathrm{V}$ is relatively small, about 0.7 of the length of basipodite; endopodite of uropod II with 2 ventrolateral spines, without dorsolateral spines; retinacula of pleopod III with 2 coupling hooks and large simple bristle....

N. novorossicus sp.n.

- Basipodite of pereopod VII is clearly concave along the posterior margin in $\sigma^{7} \sigma^{7}$; propodus of PVI is about 7.8-8 times longer than its width; propodus of $\mathrm{PV}$ is about 8.8 times longer than its width; coxal gill $\mathrm{V}$ is relatively large, about 0.9 times of the length of basipodite; endopodite of uropod II with 3 dorsolateral spines; retinacula of pleopod III with 2 coupling hooks only .... .N. ashamba sp.n.

\section{Discussion}

The discovery of hidden diversity in the Niphargus "tauricus" ingroup in the most southwestern foothills of the Caucasus indicates the poor knowledge of the real biodiversity of the area. It is believed that this area (Novorossyisk and Gelendzhik districts of the Krasnodar Krai) is quite arid for subterranean animals with about $750-800 \mathrm{~mm}$ of precipitation per year, twothirds of which fall in winter. At the same time, it is just the first insight using integrative taxonomy that revealed the rich subterranean fauna ithere, represented by unique relict allopatric species with rarther restricted distribution ranges. The diversity of epigean species of the genus Niphargus, including N. hrabei S. Karaman, 1932 new to the Russian fauna (Palatov, Marin, 2021), and recenty described N. bzhidik Marin, Krylenko et Palatov, 2021, living in both surface and subterranean habitats (Marin et al., 2021), were recently also described from this area. Further research and study of this ingroup will be continued both along the Black Sea coast and in more remote mountainous areas. It is likely that new species will be discovered in the neigbouring areas in the future. DNA barcoding using COI mtDNA gene marker is employed for their identification, because the morphological differences between already discovered species are relatively small, even minute. Such small morphological differences are due to similar conditions in underground habitats. Moreover, genetic and geographical isolation mutually support taxonomic significance of such allopatric taxa, which also depends largely on the accepted species concept (e.g., Wiens, Penkrot, 2002). In addition, this study contributes to the expansion of our knowledge about cryptic diversity of subterannean animals, supporting the overall progress towards integrative taxonomy (Padial et al., 2010; Schlick-Steiner et al., 2010; Brad et al., 2015). 
The distribution and way of dispersal of Niphargus species represent complex scientific issues. Currently, there are two main ecological groups of the species - epigean, living in the surface waters, which have significant distribution areas, usually in the basins of large rivers, for example, the Danube (e.g., CopilaşCiocianu et al., 2017, 2018), and subterranean (=stygobiotic) species, whose distribution is usually extremely narrow, sometimes limited to only one or a group of nearby caves or springs (Fišer et al., 2006; Lefébure et al., 2006, 2007; McInerney et al., 2014; Eme et al., 2017; Delić et al., 2017); the latter group is usually of relict origin. Frequent river floods are considered to be the main routes of distribution for epigean species (Copilaş-Ciocianu et al., 2017, 2018), while the distribution of subterranean species is usually associated with ancient fluctuations in the level of the ancient Tethys Sea in Europe, or its later (Miocene) separated basins such as Paratethys etc. (Fišer et al., 2007; Eme et al., 2017; Delić et al., 2017; Stoch et al., 2020).

Our reconstruction of the phylogenetic relationships of the "tauricus" ingroup (Fig. 1) compared to the recent time-calibrated phylogeny of the genus Niphargus (McInerney et al., 2014; Copilaş-Ciocianu et al., 2018) allowed us to estimate the age of its origin. Probably, the isolation of the putative ancestor (EP) from the European species of the "stygius" species group, including species from Northern Italy, Switzerland and Slovenia (CP), occurred approximately 14-11 Mya, most likely due to the regression of Paratethys to the main basins - Central (CP) and Eastern Paratethys (EP) in the Late Miocene (e.g., Rogl, Steininger, 1983, Dolukhanov, 1988; Müller et al., 1999; Popov et al., 2004, 2006; Neubauer et al., 2015). Later, in the Pliocene, the western part of the eastern Paratethys was reduced to the Black Sea (freshwater basin) (Popov et al., 2004, 2006; Neubauer et al., 2015), and the ancestor of the "tauricus" ingroup appeared along its shores. And finally, the modern species distribution was shaped by the uplift of Caucasian coastal mountain ridges and karst separation occur- ring during the last 2-3 Mya, in Late Pliocene - Early Pleistocene (see Fig. 1). According to our data, the splits to the subclades (species) within the "tauricus" ingroup took place before the beginning of the Quaternary glaciations, which allowed them to survive in some subterranean habitats during cold times. This pattern is quite congruent with that of other known Caucasian species groups (Marin, Palatov, 2021; Marin et al., 2021), which strengthen the hypothesis that the origin and isolation of all the main Caucasian species groups occurred during the Late Miocene.

We believe that the ancestors of the "tauricus" ingroup were freshwater animals that inhabited the Black Sea basin, when it the Black Sea was represented by a fresh lake, during certain periods of Pliocene and later. Very remarkable is the correlation of the age of the main subclade division, especially main subclades of the Caucasian Clade I (A-D), with formation of various coastal mountain ridges (massifs) (Fig. 3 ), which supports the past historical fluctuations in the level and salinity of the Black Sea basin. When, retreating, it left niphargids in karst and other rock cavities, where they live to the present time. In this way the species of this ingroup settled in Romania, Crimean Peninsula and Caucasus in the Late Miocene-Pliocene, whereas any other ways of their distribution seem unlikely. The current allopatric distribution of the species over the neighbouring mountain ridges and strict endemism also confirm their relict origin.

It also needs to be pointed out that the species of the "tauricus" ingroup are narrow endemics (see Fig. 2), representing unique ancient genetic lineages. Similar to other subterranean Niphargus species (e.g., McInerney et al., 2014), they are unable to disperse from current habitats, degradation of which will lead their extinction (Delić et al., 2017). At the same time, this area is characterised by significant human activity. Recent discovery of these new species which reveals the hidden diversity of subterranean crustacean fauna is a clear indication that these habitats must be protected. 


\section{Compliance with ethical standards}

CONFLICTS OF INTEREST: The authors declare that they have no conflicts of interest.

Supplementary data. The following materials are available online.

Supplement 1. Morphological comparison of the species of Niphargus "tauricus" ingroup.

\section{Acknowledgements}

The study is partly supported by the Russian Foundation for Basic Research (grants No. 2004-00803_A(DP) and 18-34-20105_mol_a_ved (DP)). Authors are very thankful to Dr. Veronika Maslova(INTS, Sevastopol), Dr. Vyacheslav Krylenko (Southern branch of IO RAS, Gelendzhik) and Olga N. Bykhalova (Utrish State Nature Reserve) for the help during the sampling. Authors are also very thankful to the anonymous reviewer greatly improving the manuscript; and Dr. Russell Sheil (The University of Adelaide) for his valuable remarks and English verification of the final text of the paper.

\section{References}

Antić D., Makarov S. 2016. The Caucasus as a major hotspot of biodiversity: Evidence from the millipede family Anthroleucosomatidae (Diplopoda, Chordeumatida) // Zootaxa. Vol.4211. No.1. P.1-205. https:// doi.org/10.11646/zootaxa.4211.1.1

Antić D.Ž., Reip H.S. 2020. The millipede genus Leucogeorgia Verhoeff, 1930 in the Caucasus, with descriptions of eleven new species, erection of a new monotypic genus and notes on the tribe Leucogeorgiini (Diplopoda: Julida: Julidae) // European Journal of Taxonomy. Vol.713.P.1-106.https://doi.org/10.5852/ ejt.2020.713

Antić D.Ž., Turbanov I.S., Reboleira A.S.P.S. 2018. From the depths: Heterocaucaseuma deprofundum sp.n., the world's deepest-occurring millipede (Diplopoda, Chordeumatida, Anthroleucosomatidae) from caves in the western Caucasus // Zootaxa. Vol.4377. No.1. P.110-124. https://doi.org/10.11646/zootaxa.4377. 1.7

Bargrizaneh Z., Fišer C., Esmaeili-Rineh S. 2021. Groundwater amphipods of the genus Niphargus Schiødte, 1834 in Boyer-Ahmad region (Iran) with description of two new species // Zoosystema. Vol.43. No.7. P.127144. https://doi.org/10.5252/zoosystema2021v43a7.

Belousov I.A., Koval A.G. 2009. To the knowledge of the aphenopsoid trechine beetles (Coleoptera, Carabidae, Trechini) of the Caucasus // Caucasian Entomological Bulletin. Vol.5. No.2. P.163-173. https://doi.org/ 10.23885/1814-3326-2009-5-2-163-173
Belousov I.A., Koval A.G. 2011. A new cave-dwelling species of the genus Cimmerites Jeannel, 1928 (Coleoptera: Carabidae: Trechini) from the West Caucasus // Zoosystematica Rossica. Vol.20. No.1. P.4853. https://doi.org/10.31610/zsr/2011.20.1.48

Birštein J.A., Borutzky E.V. 1950. [Life in the Subterranean Waters] // Zhizn' presnykh vod. Vol.3 Moscow: AN SSSR Publ. P.683-706 [in Russian].

Birštein J.A. 1950. [The Cave Fauna of Western Transcaucasia] // Zoologichesky Zhurnal. Vol.29. P.354-366 [in Russian].

Birštein J.A. 1961. [The subterranean amphipods of the Crimea] // Bulleten' Moskovskogo obshchestva ispytatelei prirody. Otdel Biologicheskiy. Vol.66. No.6. P.126-144 [in Russian].

Birštein J.A., Ljovuschkin S.I. 1968. Biospeleologica sovietica 37 . The order Bathynellacea (Crustacea, Malacostraca) in the U.R.S.S. II. The Parabathynellidae family and a zoogeographical review // Bulleten' Moskovskogo obshchestva ispytatelei prirody, Otdel Biologiceskiy. Vol.73. No.6. P.55-64 [in Russian].

Bouckaert R., Vaughan T.G., Barido-Sottani J., Duchêne S., Fourment M., Gavryushkina A., Heled J., Jones G., Kühnert D., De Maio N., Matschiner M., Mendes F.K., Müller N.F., Ogilvie H.A., du Plessis L., Popinga A., Rambaut A., Rasmussen D., Siveroni I., Suchard M.A., Wu Ch., Xie D., Zhang C., Stadler T., Drummond A.J. 2019. BEAST 2.5: An advanced software platform for Bayesian evolutionary analysis // PLoS Computational Biology. Vol.15. No.4. e1006650. https://doi.org/10.1371/journal.pcbi.1006650

Bouckaert R., Heled J., Kühnert D., Vaughan T., Wu Ch., Xie D., Suchard M.A., Rambaut A., Drummond A.J. 2014. Beast 2: a software platform for Bayesian evolutionary analysis // PLoS Computational Biology. Vol.10. e1003537. https://doi.org/10.1371/journal. pcbi. 1003537

Brad T., Fišer C., Flot J.-F., Sarbu S.M. 2015. Niphargus dancaui sp. n. (Amphipoda, Niphargidae) - a new species thriving in sulfidic groundwaters in southeastern Romania // European Journal of Taxonomy. Vol.164. P.1-28. https://doi.org/10.5852/ejt.2015.164

Chertoprud E.M., Palatov D.M., Vinarski M.V. 2020. Revealing the stygobiont and crenobiont Mollusca biodiversity hotspot in Caucasus: Part II. Sitnikovia gen. n., a new genus of stygobiont microsnails (Gastropoda: Hydrobiidae) from Georgia // Zoosystematica Rossica. Vol.29. No.2. P.258-266. https://doi.org/ 10.31610/zsr/2020.29.2.258

Chertoprud E.M., Palatov D.M., Vinarski M.V. 2021. Revealing the stygobiont and crenobiont Mollusca biodiversity hotspot in the Caucasus: Part III. Revision of stygobiont microsnails (Mollusca, Gastropoda, Hydrobiidae) from the Russian part of Western Transcaucasia, with the description of new taxa // Zootaxa. Vol.5005. No.3. P.257-275. https://doi.org/ 10.11646/zootaxa.5005.3.2

Coleman C.O., Myers A.A. 2000. New Amphipoda from Baltic amber // Polskie Archiwum Hydrobiologii. Vol.47. P.457-464. 
Copilaş-Ciocianu D., Fišer C., Borza P., Balázs G., Angyal D., Petrusek A. 2017. Low intraspecific genetic divergence and weak niche differentiation despite wide ranges and extensive sympatry in two epigean Niphargus species (Crustacea: Amphipoda) // Zoological Journal of the Linnean Society. Vol.181. P. 485-499. http://doi.org/10.1093/zoolinnean/zlw031

Copilaş-Ciocianu D., Fišer C., Borza P., Petrusek A. 2018. Is subterranean lifestyle reversible? Independent and recent large-scale dispersal into surface waters by two species of the groundwater amphipod genus Niphargus // Molecular Phylogenetics and Evolution. Vol.119. P.37-49. https://doi.org/10.1016/j.ympev.2017. 10.023

Dancău D. 1964. Noi contribuții la studiul amfipodelor subterane Niphargus dobrogicus n. sp. // Lucrările Institutului de Speologie "Emil Racoviță". Vol.3. P.397-403.

Delić T., Trontelj P., Rendos M., Fišer C. 2017. The importance of naming cryptic species and the conservation of endemic subterranean amphipods // Scientific Reports. Vol.7. No.1. P.3391. http://doi.org/ 10.1038/s41598-017-02938-z

Dolukhanov P.M. 1988. [History of the Mediterranean seas]. Moscow: Nauka Publ. [In Russian]

Drummond A.J., Bouckaert R.R. 2015. Bayesian evolutionary analysis with BEAST. Cambridge University Press, Cambridge, UK.

Drummond A.J., Suchard M.A., Xie D., Rambaut A. 2012. Bayesian phylogenetics with BEAUti and the BEAST 1.7 // Molecular Biology and Evolution. Vol.29. P.1969-1973. http://doi.org/10.1093/molbev/mss075

Eme D., Zagmajster M., Delić T., Fišer C., Flot J.-F., Konecny-Dupré L., Pálsson S., Stoch F., Zakšek V., Douady C.J., Malard F. 2017. Do cryptic species matter in macroecology? Sequencing European groundwater crustaceans yields smaller ranges but does not challenge biodiversity determinants // Ecography. Vol.41. P.424-436. https://doi.org/10.1111/ ecog. 02683

Esmaeili-Rineh S., Heidari F., Fišer C., Akmali V. 2016. Description of new endemic species of the genus Niphargus Schiödte, 1849 (Amphipoda: Niphargidae) from a karst spring in Zagros Mountains in Iran // Zootaxa. Vol.4126. P.338-350. https://doi.org/ 10.11646/zootaxa.4126.3.2

Esmaeili-Rineh S., Sari A. 2013. Two new species of Niphargus Schiödte, 1849 (Crustacea: Am-phipoda: Niphargidae) from two caves in Iran // Journal of Natural History. Vol.47.P.2649-2669. https://doi.org/ 10.1080/00222933.2013.802041

Esmaeili-Rineh S., Sari A., Delić T., Moškriè A., Fišer C. 2015a. Molecular phylogeny of the subterranean genus Niphargus (Crustacea: Amphipoda) in the Middle East: a comparison with European niphargids // Zoological Journal of the Linnaean Society. Vol.175. P.812-826. https://doi.org/10.1111/zoj.12296

Esmaeili-Rineh S., Sari A., Fišer C. 2015b. Making future taxonomy of Niphargus (Crustacea: Amphipoda: Niphargidae) in the Middle East easier: DELTA data- base of Middle East species with description of four new species from Iran // Zootaxa. Vol.4020. P.401430. https://doi.org/10.11646/zootaxa.4020.3.1

Ezard T., Fujisawa T., Barraclough T. 2009. SPLITS: species limits by threshold statistics. R Package. version 1.0-14/r31. Available at: http://r-forge.r-project. org/projects/splits/

Fišer C., Sket B., Stoch, F. 2006. Distribution of four narrowly endemic Niphargus species (Crustacea: Amphipoda) in the western Dinaric region with description of a new species // Zoologischer Anzeiger. Vol.245. P.77-94. https://doi.org/10.1016/j.jcz.2006.05.003

Fišer C., Zakšek V., Zagmajster M., Sket B. 2007. Taxonomy and biogeography of Niphargus steueri (Crustacea: Amphipoda) // Limnology. Vol.8. No.3. P.297309. https://doi.org/10.1007/s10201-007-0221-5

Fišer C., Çamur-Elipek B., Özbek M. 2009. The subterranean genus Niphargus (Crustacea, Amphipoda) in the Middle East: a faunistic overview with descriptions of two new species // Zoologischer Anzeiger. Vol.248. P.137-150. https://doi.org/10.1016/j.jcz.2009.03.003

Fišer C., Alther R., Zakšek V., Borko Š., Fuchs A., Altermatt F. 2018a. Translating Niphargus barcodes from Switzerland into taxonomy with a description of two new species (Amphipoda, Niphargidae) // Zookeys. Vol.760. P.113-141. http://doi.org/10.3897/zookeys. 760.24978

Fišer C., Robinson C.T., Malard F. 2018b. Cryptic species as a window into the paradigm shift of the species concept // Molecular Ecology. Vol.27. P.613-635. doi:10.1111/ijlh.12426

Fišer C., Delić T., Luštrik R., Zagmajster M., Altermatt F. 2019. Niches within a niche: ecological differentiation of subterranean amphipods across Europe's interstitial waters // Ecography. Vol.42. P.1212-1223. http://dx.doi.org/10.1111/ecog.0398

Folmer O., Black M., Hoeh W., Lutz R., Vrijenhoek R. 1994. DNA primers for amplification of mitochondrial cytochrome c oxidase subunit I from diverse metazoan invertebrates // Molecular Marine Biology and Biotechnology. Vol.3. P.294-299.

Giachino P.M. 2011. Catops cavicis n. sp. from the Krubera-Voronya Cave (Abkhazia, Caucasus): an interesting species of the C. alpinus group (Sensu Perreau, 2000) (Coleoptera, Cholevidae) // Boletín de la SEA. Vol.49. P.87-89.

Golovatch S.I. 2011. The millipede genus Caucasodesmus Golovatch, 1985, with the description of a new species from the Crimea, Ukraine (Polydesmida, Diplopoda, Trichopolydesmidae) // ZooKeys. Vol.93. No.1. P.18. http://doi: 10.3897/zookeys.93.1159

Golovatch S.I., Chumachenko Y.A. 2013. The millipede Typhloglomeris caucasica Golovatch, 1975 found epigeically (Diplopoda, Glomerida, Glomeridellidae) // Biodiversity Data Journal. Vol.1. e981. http:// doi:10.3897/BDJ.1.e981

Golovatch S.I., Evsyukov A.P., Reip H. 2016. The millipede family Polydesmidae in the Caucasus (Diplopoda: Polydesmida) // Zootaxa. Vol.4085. No.1. P.1-51. http://doi.org/10.11646/zootaxa.4085.1.1 
Golovatch S., Palatov D., Turbanov I., Kniss V., Gazaryan S., Snitko V., Decu V., Juberthie C., Nazareanu G. 2018. Subterranean biota of the European part of Russia: A review // Invertebrate Zoology. Vol.15. No.2. P.153-213. http://doi.org/10.15298/invertzool.15.2.01

Gongalsky K.B., Taiti S. 2014. A new cavenicolous species of Typhloligidium Verhoeff, 1918 (Isopoda: Oniscidae: Ligiidae) from the Caucasus // Arthropoda Selecta. Vol.23. No.1.P.51-56.http://doi.org/10.7868/ S0044513416110052

Grego J., Hofman S., Mumladze L., Falniowski A. 2017. Agrafia Szarowska et Falniowski, 2011 (Caenogastropoda: Hydrobiidae) in the Caucasus // Folia Malacologica. Vol.25. No.4. P.237-247. https://doi.org/ 10.12657/folmal.025.025

Grego J., Mumladze L., Falniowski A., Osikowski A., Rysiewska A., Palatov D., Hofman S. 2020. Revealing the stygobiont and crenobiont Mollusca biodiversity hotspot in Caucasus: Part I. The phylogeny of stygobiont Sadlerianinae Szarowska, 2006 (Mollusca; Gastropoda; Hydrobiidae) from Georgia with description of five new genera and twenty-one new species // ZooKeys. Vol.955. P.1-77. https://doi.org/10.3897/ zookeys.955.51983

Guy-Haim T., Simon-Blecher N., Frumkin A., Naaman I., Achituv Y. 2018. Multiple transgressions and slow evolution shape the phylogeographic pattern of the blind cave-dwelling shrimp Typhlocaris // PeerJ. Vol.6. e5268. https://doi.org/10.7717/peerj.5268

Hebert P.D., Ratnasingham S., de Waard J.R. 2003. Barcoding animal life: cytochrome c oxidase subunit 1 divergences among closely related species // Proceedings of the Royal Society of London. Series B: Biological Sciences. Vol.270. Suppl.1. P.96-99. https:// doi.org/10.1098/rsbl.2003.0025

Jażdżewski K., Kupryjanowicz J. 2010. One more fossil niphargid (Malacostraca: Amphipoda) from Baltic amber// Journal of Crustacean Biology. Vol.30. P.413416. https://doi.org/10.1651/09-3259.1

Jordana R., Baquero E., Reboleira S., Sendra A. 2012. Reviews of the genera Schaefferia Absolon, 1900, Deuteraphorura Absolon, 1901, Plutomurus Yosii, 1956 and the Anurida Laboulbène, 1865 species group without eyes, with the description of four new species of cave springtails (Collembola) from Krubera-Voronya cave, Arabika Massif, Abkhazia // Terrestrial arthropod reviews. Vol.5. No.1.P.5-85. https://doi.org/ $10.1163 / 187498312$ X622430

Karaman G.S. 2012. New species of the subterranean genus Niphargus Schiödte, 1849 (Amphipoda, Gammaridea, Niphargidae) from Russia, N. krasnodarus sp.n. (Contribution to knowledge of Amphipoda 256) // Biologia Serbica. Vol.34. No.1. P.12-16.

Kimura M. 1980. A simple method for estimating evolutionaryrates of base substitutions through comparative studies of nucleotide sequences // Journal of Molecular Evolution. Vol.16. No.2. P.111-120. https://doi.org/10.1007/BF01731581

Kolesnikov V., Turbanov I., 2020. The cave-dwelling false scorpion genus Pseudoblothrus Beier, 1931 (Arach- nida: Pseudoscorpiones: Syarinidae) in the Crimean Peninsula // Zootaxa. Vol.4374. No.4. P.524-544. https://doi.org/10.11646/zootaxa.4374.4.4

Krever V., Zazanashvili N., Jungius H., Williams L., Petelin D. 2001. Biodiversity of the Caucasus ecoregion. Moscow: World Wide Fund for Nature.

Lefébure T., Douady C.J., Gouy M., Trontelj P., Briolay J., Gibert J. 2006. Phylogeography of a subterranean amphipod reveals cryptic diversity and dynamic evolution in extreme environments // Molecular Ecology. Vol.15. P.1797-1806. http://doi.org/10.1111/j.1365294X.2006.02888.x

Lefébure T., Douady C.J., Malard F., Gibert J. 2007. Testing dispersal and cryptic diversity in a widely distributed groundwater amphipod (Niphargus rhenorhodanensis) // Molecular Phylogenetics and Evolution. Vol.42. P.676-686. http://doi.org/10.1016/ j.ympev.2006.08.020

Marin I.N. 2017. COXI based phylogenetic analysis of Caucasian clade of European Troglocaris s.1. (Crustacea: Decapoda: Atyidae) with the suggestion of a new taxonomic group structure // Biosystems Diversity. Vol.25. No.4. P.323-327. https://doi.org/10.15421/ 011749

Marin I. 2018. Cryptic diversity of stygobiotic shrimp genus Xiphocaridinella Sadowsky, 1930 (Crustacea: Decapoda: Atyidae): the first case of species cooccurrence in the same cave system in the Western Caucasus // Zootaxa. Vol.4441. No.2. P.201-224. https://doi.org/10.11646/zootaxa.4441.2.1

Marin I.N. 2019. Crustacean "cave fishes" from the Arabika karst massif (Abkhazia, Western Caucasus): new species of stygobiotic crustacean genera Xiphocaridinella and Niphargus from the Gegskaya Cave and adjacent area // Arthropoda Selecta. Vol.28. No.2. P.225-245. https://doi.org/10.15298/arthsel. 28.2.05

Marin I.N. 2020. Stygobiotic atyid shrimps (Crustacea, Decapoda, Atyidae) from the Amtkel karst system, western Abkhazia, Caucasus, with a redescription of Xiphocaridinella osterloffi and the description of two new co-occurring species // Zoologicheskyi Zhurnal. Vol.99. No.11. P.1203-1222. https://doi.org/10. 31857/S0044513420100128

Marin I., Palatov D. 2019a. A new species of the genus Niphargus (Crustacea: Amphipoda: Niphargidae) from the south-western part of the North Caucasus // Zoology in the Middle East. Vol.65. No.4. P.336-346. https://doi.org/10.1080/09397140.2019.1663907

Marin I., Palatov D. 2019b. An occasional record of the amplexus in epigean Niphargus (Amphipoda: Niphargidae) from the Russian Western Caucasus // Zootaxa. Vol.4701. No.1. P.97-100. http://doi.org/10.11646/ zootaxa.4701.1.8

Marin I., Palatov D. 2021. Cryptic refugee on the northern slope of the Greater Caucasian Ridge: discovery of Niphargus (Crustacea: Amphipoda: Niphargidae) in the North Ossetia-Alania, North Caucasus, separated from its relatives in the late Miocene // Zoologischer Anzeiger. Vol. 292. P.163-183. https://doi.org/ 10.1016/j.jcz.2021.03.002 
Marin I., Sokolova A. 2014. Redescription of the stygobiotic shrimp Troglocaris (Xiphocaridinella) jusbaschjani Birštein, 1948 (Decapoda: Caridea: Atyidae) from Agura River, Sochi, Russia, with remarks on other representatives of the genus from Caucasus // Zootaxa. Vol.3754. No.3. P.277-298. https://doi.org/ 10.11646/zootaxa.3754.3.3

Marin I., Turbanov I. 2021 (in press). Molecular genetic analysis of stygobiotic shrimps of the genus Xiphocaridinella (Crustacea: Decapoda: Atyidae) revealed a connection between distant caves in Central Abkhazia, southwestern Caucasus // International Journal of Speleology.

Marin I., Krylenko S., Palatov D. 2021. The Caucasian relicts: a new species of the genus Niphargus (Crustacea: Amphipoda: Niphargidae) from the GelendzhikTuapse area of the Russian southwestern Caucasus // Zootaxa. Vol.4963. No.3. P.483-504. https://doi.org/ 10.11646/zootaxa.4963.3.5

McInerney C.E., Maurice L., Robertson A.L., Knight L.R.F.D., Arnscheidt J., Venditti C., Dooley J.S.G., Mathers T., Matthijs S., Eriksson K., Proudlove G.S., Hänfling B. 2014. The ancient Britons: groundwater fauna survived extreme climate change over tens of millions of years across NW Europe // Molecular Ecology. Vol.23. P.1153-1166. https://doi.org/10. $1111 / \mathrm{mec} .12664$

Myers N., Mittermeier R.A., Mittermeier C.G., da Fonseca G.A.B., Kent J. 2000. Biodiversity hotspots for conservation priorities // Nature. Vol.403. P.853-858. https://doi.org/10.1038/35002501

Müller P., Geary D.H., Magyar I. 1999. The endemic molluscs of the Late Miocene Lake Pannon: their origin, evolution and family-level taxonomy // Lethaia. Vol.32. No.1. P.47-60. https://doi.org/10.1111/ j.1502-3931.1999.tb00580.x

Neubauer T.A., Harzhauser M., Kroh A., Georgopoulou E., Mandic O. 2015. A gastropod-based biogeographic scheme for the European Neogene freshwater systems // Earth-Science Reviews. Vol.143. P.98-116. https://doi.org/10.1016/j.earscirev.2015.01.010

Padial J.M., Miralles A., De la Riva I., Vences M. 2010. The integrative future of taxonomy // Frontiers in Zoology. Vol.7. P.16. https://doi.org/10.1186/17429994-7-16

Palatov D.M., Marin I.N. 2021. Epigean (pond-dwelling) species of the genus Niphargus Schiödte, 1849 (Crustacea, Amphipoda, Niphargidae) from the coastal plains of the Black and Azov seas of the north- and south-western Caucasus // Invertebrate Zoology. Vol.18. No.2. P.105-151. https://doi.org/10.15298/ invertzool.18.2.05

Pons J., Barraclough T.G., Gomez-Zurita J., Cardoso A., Duran D.P., Hazell S., Kamoun S., Sumlin W.D., Vogler A.P. 2006. Sequencebased species delimitation for the DNA taxonomy of undescribed insects // Systematic Biology. Vol.55. P.595-609. https:// doi.org/10.1080/10635150600852011

Popov S.V., Rögl F., Rozanov A.Y., Steininger F.F., Shcherba I.G., Kovac M. 2004. Lithological-Paleo- geographic maps of the Paratethys. 10 maps Late Eocene to Pliocene // Courier Forschungsinstitut Senckenberg. Vol.250. P.1-46.

Popov S.V., Shcherba I.G., Ilyina L.B., Nevesskaya L.A., Paramonova N.P., Khondkarian S.O., Magyar I. 2006. Late Miocene to Pliocene palaeogeography of the Paratethys and its relation to the Mediterranean // Palaeogeography, Palaeoclimatology, Palaeoecology. Vol.238. P.91-106. http://dx.doi.org/10.1016/j. palaeo.2006.03.020.

Puillandre N., Lambert A., Brouillet S., Achaz G. 2011. ABGD, Automatic Barcode Gap Discovery for primary species delimitation // Molecular Ecology. https:// doi.org/10.1111/j.1365-294X.2011.05239.x

Reboleira A., Ortuno V.M. 2014. A new species of Duvalius from world's deepest cave (Coleoptera: Carabidae) // Zootaxa. Vol.3784. No.3. P.267-274. https:// doi.org/10.11646/zootaxa.3784.3.6

Reid N.M., Carstens B.C. 2012. Phylogenetic estimation error can decrease the accuracy of species delimitation: A Bayesian implementation of the general mixed Yule-coalescent model // BMC Evolutionary Biology. Vol.12. No.1. P.196. https://doi.org/10.1186/14712148-12-196

Rögl F., Steininger F.F. 1983. Vom Zerfall der Tethys zu Mediterran und Paratethys. Die neogene Paläogeographie und Palinspastik des zirkum-mediterranen Raumes // Annalen des Naturhistorischen Museums in Wien. Bd.85A. S.135-163.

Schlick-Steiner B.C., Steiner F.M., Seifert B., Stauffer C., Christian E., Crozier R.H. 2010. Integrative Taxonomy: A Multisource Approach to Exploring Biodiversity // Annual Review of Entomology. Vol.55. P.421438. http://dx.doi.org/10.1146/annurev-ento-112408085432

Sidorov D.A. 2015. The spring-dwelling amphipod genus Lyurella (Peracarida, Amphipoda): Systematics, distribution, and affinity, with description of the second representative from the Black Sea coast region // Crustaceana. Vol.88. No.1. P. 27-50. https://doi.org/ 10.1163/15685403-00003392

Sidorov D.A. 2016. Zenkevitchia karamani, a distinct new species of admirabilis-group (Crustacea: Amphipoda: Typhlogammaridae) from Abkhazia // Ecologica Montenegrina. Vol.9. P.21-30. https://doi.org/ 10.37828/em.2016.9.4

Sidorov D.A., Samokhin G.V. 2016. Kruberia abchasica, a new genus and species of troglobiont amphipods (Crustacea: Gammaridae) from Krubera Cave (Western Transcaucasia) // Arthropoda Selecta. Vol.25. No.4. P.373-379. https://doi.org/10.15298/arthsel.25.4.04

Sidorov D.A., Gontcharov A.A., Sharina S.N. 2015a. A new genus and two new species of cavernicolous amphipods (Crustacea: Typhlogammaridae) from Western Caucasus // European Journal of Taxonomy. No.168. P.1-32. https://doi.org/10.5852/ejt.2015.168 Sidorov D.A., Gontcharov A.A., Palatov D.M., Taylor S.J., Semenchenko A.A. 2015b. Shedding light on a cryptic cavernicole: A second species of Zenkevitchia 
Birstein (Crustacea: Amphipoda: Typhlogammaridae) discovered via molecular techniques // Subterranean Biology. Vol.15. P.37-55. https://doi.org/10.3897/ subtbiol.15.4872

Sidorov D., Taylor S., Sharina S.N., Gontcharov A.A. 2018. Zenkevitchiidae fam. n. (Crustacea: Gammaroidea), with description of new subterranean amphipods from extremely deep cave habitats // Journal of Natural History. Vol.52. No.23-24. P.1509-1535. https://doi.org/10.1080/00222933.2018.1482017

Stoch F., Christian E., Flot J.F. 2020. Molecular taxonomy, phylogeny and biogeography of the Niphargus tatrensis species complex (Amphipoda, Niphargidae) in Austria // Organisms Diversity \& Evolution. Vol.20. P.701-722. https://doi.org/10.1007/s13127-02000462-z

Tchemeris A.N. 2013. Two new harvestman species (Arachnida: Opiliones) from the collection of Siberian Zoological Museum // Arthropoda Selecta. Vol.22. No.1. P.41-46. https://doi.org/10.15298/arthsel.22.1.03

Trikhunkov Ya.I., Gaidalenok O.V., Bachmanov D.M., Marinin A.V. 2018. [Morphostructure of the junction zone of the North-West Caucasus and the KerchTaman region] // Geologiya. No.4. P.77-92 [in Russian].

Turbanov I.S., Gongalsky K.B. 2016. Typhloligidium lithophagum sp.n. (Isopoda, Oniscidea, Ligiidae), a new species of troglobiotic woodlouse from the Crimean Peninsula//Zoologicheskii Zhurnal. Vol.95. No.11. P.1277-1283. https://doi.org/10.7868/ S0044513416110052

Vargovitsh R.S. 2012. New troglomorphic Arrhopalitidae (Collembola: Symphypleona) from the Western Caucasus // Zootaxa. Vol.3174. No.1. P.1-21. https:// doi.org/10.11646/zootaxa.3174.1.1
Vargovitsh R.S. 2013. Cavernicolous Arrhopalites abchasicus sp.n. (Collembola: Symphypleona: Arrhopalitidae) from the West Caucasus with a key to the World species of the genus // Zootaxa. Vol.3666. No.1. P.16-30. https://doi.org/10.11646/zootaxa. 3666.1.2

Vinarski M.V., Palatov D.M. 2019. A survey of the Belgrandiella-like gastropods of the Northern Black Sea region (Mollusca, Gastropoda, Hydrobiidae s.1.): morphological variability and morphospecies // Zoologicheskiy Zhurnal. Vol.98. No.7. P.988-1002. https:// doi.org/10.1134/S0044513419070122

Vinarski M.V., Palatov D.M., Glöer P. 2014. Revision of 'Horatia' snails (Mollusca, Gastropoda, Hydrobiidae sensu lato) from South Caucasus with description of two new genera // Journal of Natural History. Vol.48. No.37-38. P.2237-2253. https://doi.org/10.1080/ 00222933.2014 .917210

Wiens J.J., Penkrot T.A. 2002. Delimiting species using DNA and Morphological variation and discordant species limits in spiny lizards (Sceloporus) // Systematic Biology. Vol.51.P.69-91.https://doi.org/10.1080/ 106351502753475880

Zakšek V., Delić T., Fišer C., Jalžić B., Trontelj P. 2019. Emergence of sympatry in a radiation of subterranean amphipods // Journal of Biogeography. Vol.46. No.3. P.657-669. https://doi.org/10.1111/jbi.13514

Zhang J., Kapli P., Pavlidis P., Stamatakis A. 2013. A general species delimitation method with applications to phylogenetic placements // Bioinformatics. Vol.29. P.2869-2876. https://doi.org/10.1093/bioinformatics/ btt499

Responsible editor A.A. Kotov 